
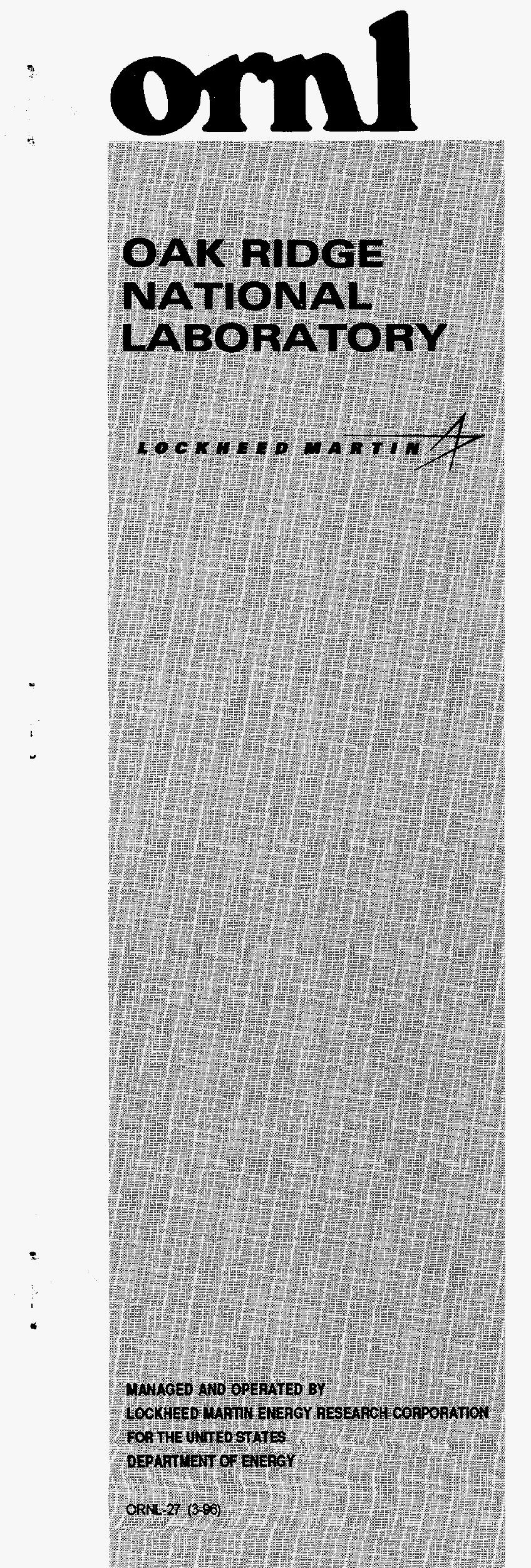

NMUEEO AND OPERATED BY LOCKHEED WAHTH EIERGY RES EARCH CORPORA TION FOB THE UITEO STITES OEPARTIENT OF EIERGY

\section{RECEIVED \\ OCT 28 H \\ Osti}

ORNL/TM-13410

\section{The X-625 Groundwater Treatment Facility: A Field-Scale Test of} Trichloroethylene Dechlorination Using Iron Filings for the $X-120 /$ X-749 Groundwater Plume

\author{
L. Liang \\ O. R. West \\ N. E. Korte \\ J. D. Goodlaxson \\ D. A. Pickering \\ J. L. Zutman \\ F. J. Anderson \\ C. A. Welch \\ M. J. Pelfrey \\ M. J. Dickey
}


This report has been reproduced directly from the best available copy.

Available to DOE and DOE contractors from the Office of Scientific and Technical

Information, P.O.Box 62, Oak Ridge, TN 37831; prices available from (423) 576-8401, FTS 626-8401.

Available to the public from the National Technical information Service, U.S. Department

of Commerce, 5285 Port Royal Rd., Springfield, VA 22161

This report was prepared a an account of work sponsored by an agency of the United States Govemment. Neither the United States Government nor any agency thereof, nor any of their employees, makes any warranty, express or implied, or assumes any legal liability or responsibility for the accuracy, completeness, or usefulness of any information, apparatus, product, or process disclosed, or represents that its use would not infringe privately owned rights. Reference herein to any specific commercial product, process, or service by trade name, trademark, manufacturer, or otherwise, does not necessarily constitute or imply its endorsement, recommendation, or favoring by the United States Government or any agency thereof. The view and opinions of authors expressed herein do not necessarily state or reflect those of the UnitedStatesGovemment or any agency thereof. 


\section{DISCLAIMER}

Portions of this document may be illegible electronic image products. Images are produced from the best available original document. 


\title{
THE X-625 GROUNDWATER TREATMENT FACILITY A Field-Scale Test of Trichloroethylene Dechlorination Using Iron Filings for the X-120/X-749 Groundwater Plume
}

L. Liang ${ }^{1}$, O. R. West ${ }^{1}$, N. E. Korte' ${ }^{2}$, J. D. Goodlaxson', D. A. Pickering ${ }^{2}$, J. L. Zutman ${ }^{2}$ F. J. Anderson ${ }^{3}$, C. A. Welch ${ }^{3}$, M. J. Pelfrey ${ }^{3}$, M. J. Dickey ${ }^{1}$

Environmental Sciences Division

Publication No. 4667

Date Published: September 1997

\author{
Prepared for: \\ U. S. Department of Energy \\ Piketon, Ohio \\ Prepared by: \\ OAK RIDGE NATIONAL LABORATORY \\ Oak Ridge, Tennessee 37831 \\ Managed by: \\ LOCKHEED MARTIN ENERGY RESEARCH CORPORATION \\ for the \\ U.S. DEPARTMENT OF ENERGY \\ under contract DE-AC05-96OR22464

\footnotetext{
' Oak Ridge National Laboratory, Oak Ridge, Tennessee

${ }^{2}$ Oak Ridge National Laboratory, Grand Junction, Colorado

${ }^{3}$ Portsmouth Gaseous Diffusion Plant, Piketon, Ohio

${ }^{4}$ Oak Ridge Institute for Science and Education, Oak Ridge, Tennessee
} 


\section{TABLE OF CONTENTS}

LIST OF TABLES ……...................................................................................................i

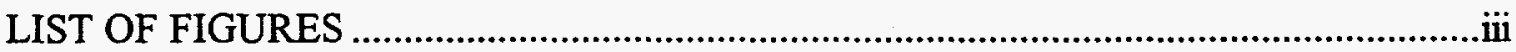

EXECUTIVE SUMMARY .....................................................................................

ACKNOWLEDGMENTS......................................................................................ii

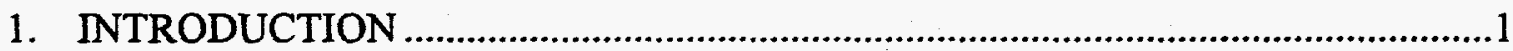

1.1 Background: Reduction of Chlorinated Solvents by Zero-Valence Iron and

Bimetallic Systems ............................................................................................

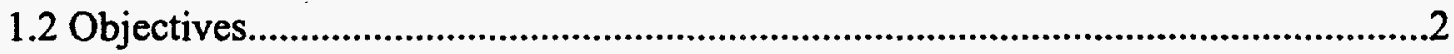

1.3 Report Organization and Scope ............................................................................2

2. SYSTEM ASSEMBLY, OPERATIONAL CHARACTERISTICS, AND

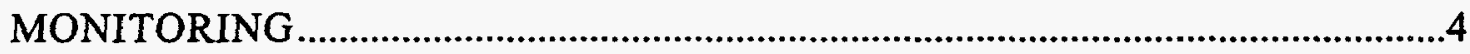

2.1 System Components ...............................................................................................

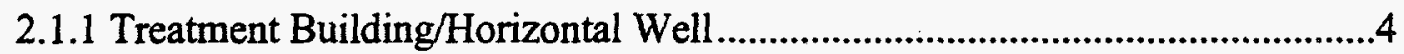

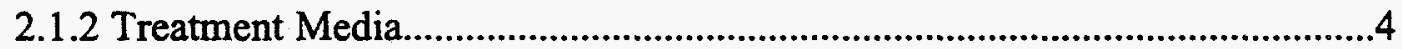

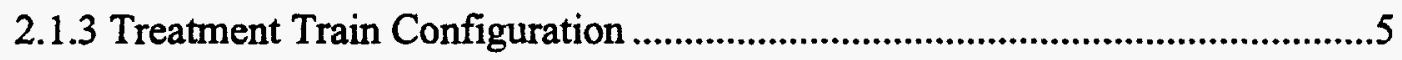

2.2 Start-up Procedures...............................................................................................11

2.3 Process Monitoring and Sample Analysis ...........................................................13

2.4 System Hydraulics ....................................................................................................13

2.5 Observations Regarding System Operation .........................................................19

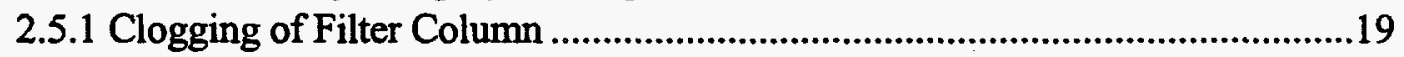

2.5.2 Gas Build-Up and Canister Clogging .........................................................20

2.5.3 Iron Oxide Precipitation............................................................................22

3. VOC DEGRADATION AND CHANGES IN WATER CHEMISTRY

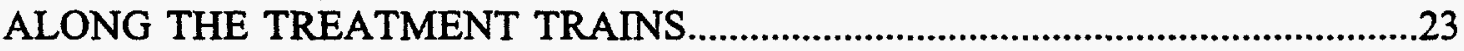

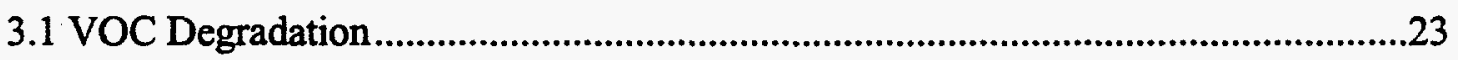

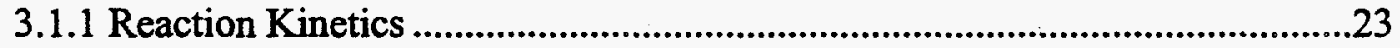

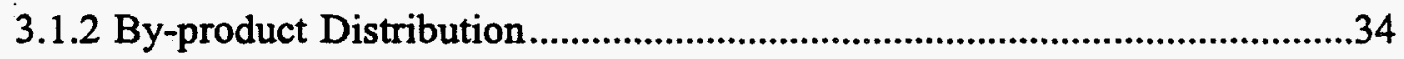

3.1.3 Laboratory Evaluation of Used Iron Filings.....................................................39

3.2 Water Chemistry ....................................................................................................40

3.2.1 Influent Water Chemistry ............................................................................40

3.2.2 pH Change in the Treatment Trains.............................................................40

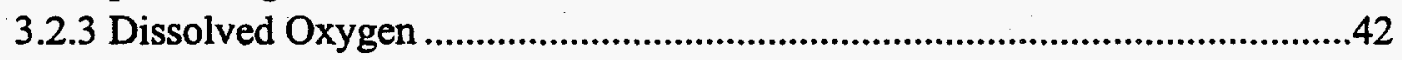

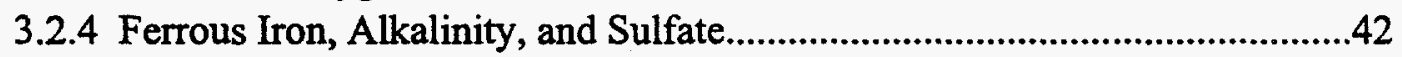

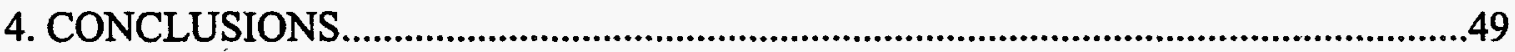

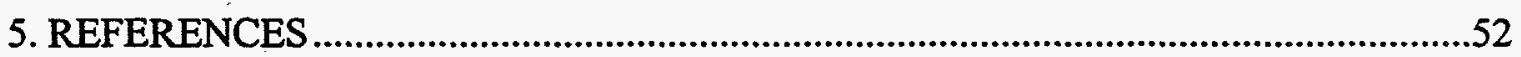

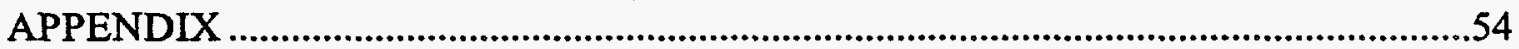




\section{LIST OF TABLES}

Table 1. Problems encountered and solutions implemented during the start-up of the X-625 Groundwater Treatment Facility.

Table 2. Summary of significant events and total volumes of groundwater passing through treatment trains.

Table 3. Summary of trichloroethylene half-lives in the Peerless treatment train.

Table 4. Summary of trichloroethylene half-lives in the Master Builders treatment train

Table 5. Summary of trichloroethylene half-lives in the palladized iron treatment train.

Table 6. Trichloroethylene half-lives in flow-through iron filing columns......................39

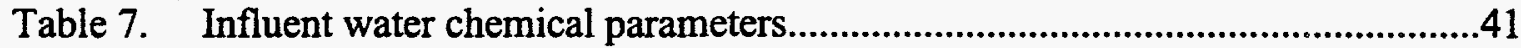

Table 8. Effluent $\mathrm{pH}$ measured in treatment trains................................................41

Table 9. Influent and effluent sulfate concentrations.................................................43

Table A.1 Concentrations of trichloroethylene and dechlorination by-products in influent and effluent streams of the Peerless treatment train.

Table A.2 Concentrations of trichloroethylene and dechlorination by-products in influent and effluent streams of the Master Builders treatment train.

Table A.3 Concentrations of trichloroethylene and dechlorination by-products in influent and effluent streams of the palladized iron treatment train. 


\section{LIST OF FIGURES}

Fig. 1. Inlet pressure at the $\mathrm{X}-725 / \mathrm{X} 120$ treatment facility

Fig. 2. Schematic of treatment trains in the X-625 Groundwater Treatment

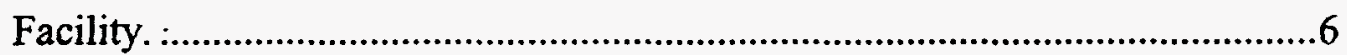

Fig. 3. Drums used for containing reactive materials..................................................8

Fig. 4. Packing of Master Builders and Peerless iron filings in canisters. ......................9

Fig. 5. Packing of palladized iron filings in canisters.......................................................9

Fig. 6. Monitoring column design........................................................................10

Fig. 7. Measured flow rates through the Master Builders treatment train...................15

Fig. 8. Measured flow rate through the Peerless treatment train..................................15

Fig. 9. Measured flow rates through palladized iron treatment train..........................16

Fig. 10. Ratio between flow and pressure drop across the first canister in the Master Builders treatment train....................................................................18

Fig. 11. Ratio between flow and pressure drop across the first canister in the Peerless treatment train................................................................................18

Fig. 12. Ratio between flow and pressure drop across the first canister in the palladized iron treatment train. ....................................................................19

Fig. 13. Photograph of cemented filings from Master Builders canister........................21

Fig. 14. Trichloroethylene degradation in Peerless canisters, measured March 12,1996 through June 6, 1996.................................................................25

Fig. 15. Ethane production in Peerless canisters, measured March 28, 1996

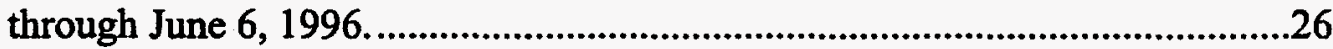

Fig. 16. Trichloroethylene degradation in Peerless canisters, measured June 19, 1996 through August 7, 1996..........................................................................26

Fig. 17. Ethane production in Peerless treatment trains, measured from June 19, 1996 through August 7, 1996.

Fig. 18. Trichloroethylene degradation in Peerless monitoring column, measured on March 28, 1996 and from July 31, 1996 through August 20, 1996.

Fig. 19. Trichloroethylene degradation in the Master Builders treatment trains (with three canisters), measured on March 12, 1996 through May 28, 1996

Fig. 20. Trichloroethylene degradation in the Master Builders treatment trains (with two canisters), measured from June 19, 1996 through August 7, 1996

Fig. 21. Trichloroethylene degradation in Master Builders monitoring column, measured on March 12, 1996 and from July 31, 1996 through August $7,1996$.

Fig. 22. Ethane production in Master Builders treatment train (three canisters), measured from April 11, 1996 through May 29, 1996.

Fig. 23. Ethane production in Master Builders treatment train (two canisters), measured from June 19, 1996 through August 7, 1996. 
Fig. 24. Molar ratio of trichloroethylene effluent and ethane effluent to trichloroethylene influent concentrations in the palladized iron treatment train. Residence times: $\sim 20 \mathrm{~min}$ for all sampling dates....................33

Fig. 25. Trichloroethylene degradation and ethane production from the palladized iron packed monitoring column, measured on March 6, 1996 and March 28, 1996.

Fig. 26. Trichloroethylene and degradation by-products observed on (a) March 6, 1996, and (b) August 7, 1996 in the Peerless media packed column. ...........36

Fig. 27. Trichloroethylene and degradation by-products observed on (a) March 6, 1996, and (b) August 7, 1996 in the packed column of Master Builder's filings.

Fig. 28. Trichloroethylene and degradation by-products observed on (a) March 6, 1996, and (b) March 28, 1996 in the column of palladized iron .38

Fig. 29. Ferrous iron and alkalinity (as $\mathrm{CaCO}_{3}$ ) in Peerless monitoring column as a function of residence time.

Fig. 30. Ferrous iron and alkalinity (as $\mathrm{CaCO}_{3}$ ) in Master Builders monitoring column.

Fig. 31. Ferrous iron and alkalinity $\left(\mathrm{as}_{\mathrm{CaCO}}\right)$ in palladized iron monitoring column.

Fig. 32. Ferrous iron and alkalinity in Master Builders and Peerless treatment trains. Samples collected from ports between canisters on $3 / 28 / 96$.

Fig. 33. Change in ferrous iron [Fe(II)] concentration in Peerless, Master Builders and palladized iron treatment trains

Fig. 34. Peerless iron filings before (a) and after approximately 5 months of use (b) at the X-625 facility. Each division on scale corresponds to $1 \mathrm{~mm}$.

Fig. 35. Master Builders iron filings before (a) and after approximately 5 months of use (b) at the X-625 facility. Each division on scale corresponds to $1 \mathrm{~mm}$.

Fig. A.1. Trichloroethylene concentrations in influent and effluent streams of the Peerless treatment train.

Fig. A.2 Concentration of ethane/ethene, vinyl chloride and cis-1,2dichloroethene (DCE) in (a) influent and (b) effluent streams of the Peerless treatment train.

Fig. A.3. Trichloroethylene concentrations in influent and effluent streams of the Master Builders treatment train.

Fig. A.4 Concentration of ethane/ethene, vinyl chloride and cis-1,2dichloroethene (DCE) in (a) influent and (b) effluent streams of the Master Builders treatment train.

Fig. A.5. Trichloroethylene concentrations in influent and effluent streams of the palladized iron treatment train. This train was shut down on May 17 and put back on-line on July 18 .

Fig. A.6 Concentration of ethane/ethene, vinyl chloride and cis-1,2dichloroethene (DCE) in (a) influent and (b) effluent streams of the 
palladized iron treatment train. This train was shut down on May 17

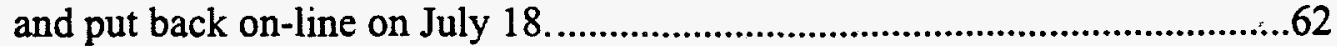




\section{EXECUTIVE SUMMARY}

The dehalogenation of chlorinated solvents by zero-valence iron has recently become the subject of intensive research and development as a potentially cost-effective, passive treatment for contaminated groundwater through reactive barriers. Because of its successful application in the laboratory and other field sites, the X-625 Groundwater Treatment Facility (GTF) was constructed to evaluate reactive barrier technology for remediating trichloroethylene (TCE)-contaminated groundwater at the Portsmouth Gaseous Diffusion Plant (PORTS). The X-625 GTF was built to fulfill the following technical objectives: (1) to test reactive barrier materials (e.g., iron filings) under realistic groundwater conditions for long term applications, (2) to obtain rates at which TCE degrades and to determine by-products for the reactive barrier materials tested, and (3) to clean up the TCE-contaminated water in the X-120 plume.

Construction of X-625 GTF was completed on February 29, 1996, and operations began on March 5, 1996. This report describes start up and operating results through midAugust, 1996. The facility consists of a horizontal well that collects TCE-contaminated groundwater from the Gallia formation underlying the X-749/X-120 Solid Waste Management Unit (SWMU), and three parallel treatment trains containing canisters filled with reactive barrier materials, through which the groundwater is diverted after collection by the horizontal well. The reactive barrier media tested at X-625 GTF are (1) fine-grade iron filings (equivalent to 40-mesh) purchased from Master Builders, Inc.; (2) stock iron filings purchased from Peerless Metal Powders \& Abrasive, Inc. (-8+50-mesh); and (3) palladized iron filings obtained by chemically plating palladium (at $0.08 \%$ of iron) on 40 mesh iron filings from Fisher Scientific. The latter is a recently developed material that was found to degrade TCE in the laboratory at rates 1 to 2 orders of magnitude faster than zero-valence iron alone.

Overall, based on sustained TCE degradation performance and suitable hydraulic characteristics (least clogging), the size of iron filings is a critical factor in selecting reactive media. The stock iron filings from Peerless appear to be the best reactive material tested to date at the X-625 GTF. However, due to recent changes in TCE degradation, it is recommended that monitoring of the Peerless treatment train be continued for at least a year to determine the long-term effectiveness of this reactive barrier material. The longterm performance data are critical for predicting the lifetime of the reactive materials. The Master Builder filings showed sustained reactivity but because of the small size used in the tests, the filings were prone to clogging and iron particle cementation. The palladized iron filings had the most rapid degradation rates; however, their performance deteriorated after several thousand pore volumes of water were treated. The poisoning may be due to sulfides produced by microbial reduction of sulfates present in the groundwater. The latter may be a problem specific to groundwater containing high sulfate levels, such as in the X-120 plume. 
The X-625 GTF is providing important field-scale and long-term data for the evaluation and design of reactive barriers at PORTS. The X-625 GTF is a unique facility not only because it is where site remediation is being performed, but it is also where research scientists and process engineers can test other promising reactive barrier materials. In addition, the data collected from X-625 GTF can be used to evaluate the technical and economic feasibility of replacing the activated carbon units in the pump-and-treat facilities at PORTS. Although preliminary conclusions have been made regarding the materials evaluated at the facility, continuous testing will be valuable to the research community as well as site owners who are interested in the development and implementation of passive reactive barrier technology for dechlorination with zerovalence iron. In the environmental remediation community, there is a misconception that reactive barriers are a permanent fix to environmental problems; once a reactive barrier is in place, no further work needs to be done and the contamination at the site is taken care of. This report shows that these reactive barriers will require close performance monitoring and maintenance, possibly including periodic regeneration and/or replacement of the barrier material. Routine monitoring of contaminant levels and geochemical parameters will allow determination of rates of clogging and change in media reactivity, thus predicting the life of a reactive barrier. 


\section{ACKNOWLEDGMENTS}

Many people have contributed to the project in different ways. John Sheppard and Bob Barnett provided much needed support throughout the work. Roger Gorres is the manager for the Remedial Actions Program of the Portsmouth Gaseous Diffusion Plant. Doug Davenport played a crucial role at the beginning of the project. Greg Wilkett from Lockwood Greene was the project coordinator during the construction of the facility. Maureen Muck, Mark Mumby, Bob Schlosser, and Melissa Jensen from the ORNL-Grand Junction office assembled the main components of the treatment system and performed the initial start-up, including installation of system modifications prior to routine operation by personnel at the Portsmouth Gaseous Diffusion Plant. Shirley Scarborough performed microbial analyses of water samples. The financial support given by the U. S. Department of Energy Portsmouth Environmental Restoration Program is gratefully acknowledged. 


\section{INTRODUCTION}

\subsection{Background: Reduction of Chlorinated Solvents by Zero-Valence Iron and Bimetallic Systems}

The dehalogenation of chlorinated solvents by zero-valence iron has recently become the subject of intensive research and development as a potentially cost-effective, passive treatment for contaminated groundwater through reactive barriers [Gillham et al., 1992, 1994; O'Hannesin et al, 1992, 1993; Vogan et al, 1994; Korte et al., 1995; Liang et al., 1995a, b; Liang et al., 1997]. This treatment process is based on the well-known fact that zero-valence iron is an effective reducing agent in comparison with many redox-reactive species. Thermodynamically, dehalogenation occurs through an electron transfer from zero-valence iron $\left(\mathrm{Fe}^{0}\right)$ to the halogenated hydrocarbons, resulting in an oxidized iron, a dehalogenated hydrocarbon, and a halogen ion, $\mathrm{X}$ :

$$
\mathrm{Fe}^{0}+\mathrm{R}-\mathrm{X}+\mathrm{H}^{+} \Rightarrow \mathrm{Fe}^{2+}+\mathrm{R}-\mathrm{H}+\mathrm{X}^{-}
$$

Although detailed reaction pathways and mechanisms have not been determined, the reaction is believed to be a heterogeneous surface reaction. As such, degradation rates vary among iron filings obtained from different sources as a result of differences in surface characteristics such as specific surface area, surface chemical composition, and extent of surface oxidation [Horney et al., 1995; Liang et. al., 1995a, b]. Laboratory studies suggest that complete dechlorination [for example, from trichloroethylene (TCE) to ethylene or ethane] in a single step is unlikely and that stepwise dechlorination must take place on the metal surface (O-Hannesin, 1993; Gillham and O-Hannesin, 1994; Matheson and Tratnyek, 1994; Sivavec and Horney, 1995; Liang et al., 1995a,b; Puls et al., 1995). Laboratory studies also show that less chlorinated compounds such as vinyl chloride (VC) are more difficult to dechlorinate than the more highly chlorinated compounds such as TCE. This implies that less chlorinated organic compounds can persist in iron-treated water at levels that are unacceptable under current cleanup requirements.

In a recent collaboration with University of Arizona, researchers in the Environmental Sciences Division at Oak Ridge National Laboratory (ORNL) found that a bimetallic preparation of $\mathrm{Fe}$ with a small amount of $\mathrm{Pd}(0.05-0.08 \%$ by weight $)$ was a superior reductant for TCE [Korte et al. 1995; Muftikian et. al. 1995; Liang et al., 1997]. The bimetallic system provided dechlorination kinetics that were one to two orders of magnitude faster than those for zero-valence iron alone. Although palladization increases the cost of the iron material, the amount of filings required to achieve the same levels of dechlorination is significantly reduced due to more rapid degradation rates. Furthermore, more complete dechlorination has been observed with the bimetallic substrate than with iron alone [Liang et al., 1997]. 
From a thermodynamic viewpoint, zero-valence iron is capable of dechlorinating a series of chlorinated compounds although the reaction rates for some compounds may be too slow for practical applications. The addition of trace amounts of a second metal (such as $\mathrm{Pd}, \mathrm{Ni}, \mathrm{Zn}$, or $\mathrm{Cu}$ ) generally enhance the reaction rates to varying degrees, but the cost of the material increases as well. In addition, the trace metals have been found to leach out into solution (R. Orth, Monsanto, Personal communication, 1996). Aside from the complexity of the dechlorination mechanisms and the kinetics of the chemical reactions, there are issues related to engineering applications. Theoretically, corrosion of iron and surface precipitation will decrease the permeability of the porous media and change groundwater residence times within the reactive barrier materials. Clogging of the permeable barrier can result in subsequent failure of the treatment system. The extent of clogging and surface precipitation will be site-specific because it depends on the chemistry and microbiology of the groundwater. Prior to the study described here, there was a knowledge gap on the long-term performance and longevity of permeable, reactive barriers made from iron filings.

\subsection{Objectives}

The X-625 Groundwater Treatment Facility (GTF) was constructed to evaluate reactive barrier technology for application at the X-120 groundwater plume underlying parts of the Portsmouth Gaseous Diffusion Plant (PORTS). The X-625 GTF was built to fulfill the following technical objectives: (1) to test reactive barrier materials (e.g., iron filings) under realistic groundwater conditions for long-term applications; (2) to obtain degradation rates, degradation by-products, and design parameters for the reactive barrier materials tested; and (3) to clean up the TCE-contaminated water in the X-120 plume.

The X-625 GTF consists of a horizontal well that collects TCE-contaminated groundwater from the Gallia aquifer underlying the $\mathrm{X}-749 / \mathrm{X}-120$ Solid Waste Management Unit (SWMU) and three parallel treatment trains containing canisters filled with granular reactive materials, through which the groundwater is diverted after collection by the horizontal well. The parallel systems allow the simultaneous evaluation of three types of reactive materials under identical groundwater conditions. This capability is critical for selecting the optimum treatment material to be used at PORTS.

Construction of the X-625 GTF was completed on February 29, 1996, and the initial testing began on March 5, 1996. Upon completion of the tests, the facility will transfer to routine operation for treating TCE-contaminated groundwater from the X-749/X-120 groundwater plume.

\subsection{Report Organization and Scope}

This report documents the construction and operation of the X-625 GTF through midAugust 1996. The assembly, characteristics, and monitoring of the treatment trains are 
described in Sect. 2. Both field and laboratory analyses of samples collected at the facility are presented in Sect. 3; TCE degradation rates and changes in water chemistry for the various treatment trains are also included in this section. Conclusions and recommendations for future work are summarized in Sect. 4. 


\section{SYSTEM ASSEMBLY, OPERATIONAL CHARACTERISTICS, AND MONITORING}

This section describes the assembly, start-up, and monitoring of the treatment trains within the X-625 GTF. The majority of the assembly activities described in this section were performed by personnel from the ORNL office in Grand Junction (GJ), Colorado. Sample collection and analyses were initially conducted by personnel from ORNLTennessee (TN) and ORNL-GJ. Subsequent samples were collected by PORTS personnel.

\subsection{System Components}

\subsubsection{Treatment Building/Horizontal Well}

The treatment facility consists of a building constructed 3 to $5 \mathrm{ft}$ below the bedrock surface and approximately $30 \mathrm{ft}$ below the natural topographic grade. Contaminated groundwater is obtained from a 1400 -ft-long horizontal well that was drilled through a sand/gravel formation (Gallia) lying above the bedrock. The horizontal well consists of a $540-\mathrm{ft}$ screened section that penetrates the X-749/X-120 groundwater plume (TCE at concentrations of 100 to $200 \mathrm{ppb}$ ). Blank casing, 400 to $500 \mathrm{ft}$ in length, is attached to each end of the screened portion of the horizontal well. One encased end of the screened section gradually descends to the treatment building. The other encased end of the screened section ascends to ground surface where it is covered and protected.

Since the beginning of facility operations, groundwater from the contaminated plume has been flowing under its natural gradient to the treatment facility. The inlet pressure measured at the point where groundwater enters the building fluctuated between 4 and 5 psi during the first few months of operation (see Fig. 1). Beginning in July, there has been a decreasing trend and average pressure readings were below $4 \mathrm{psi}$. This decrease may result from seasonal fluctuations or clogging of the horizontal well.

\subsubsection{Treatment Media}

The reactive barrier media currently being tested at the X-625 GTF are (1) fine-grade iron filings (equivalent to 40-mesh) purchased from Master Builders, Inc. (ground-engine blocks and cast iron that are $\sim 95 \%$ iron and carbon, $5 \%$ other metals and silicon); (2) stock iron filings purchased from Peerless Metal Powders and Abrasive, Inc. [metal shavings (mesh size between 8 and 50), $86 \%$ iron, 3-4\% carbon, $-3 \%$ silicon, and other trace metals]; and (3) palladized iron filings obtained by chemically plating palladium (at $0.08 \mathrm{wt} \%$ of $\mathrm{Fe}$ ) on 40 -mesh iron filings from Fisher Scientific. This palladized iron, prepared and provided by Johnson-Matthey Corporation, is recently developed and tested in laboratories, and the material has not been tested before at a contaminated site. 


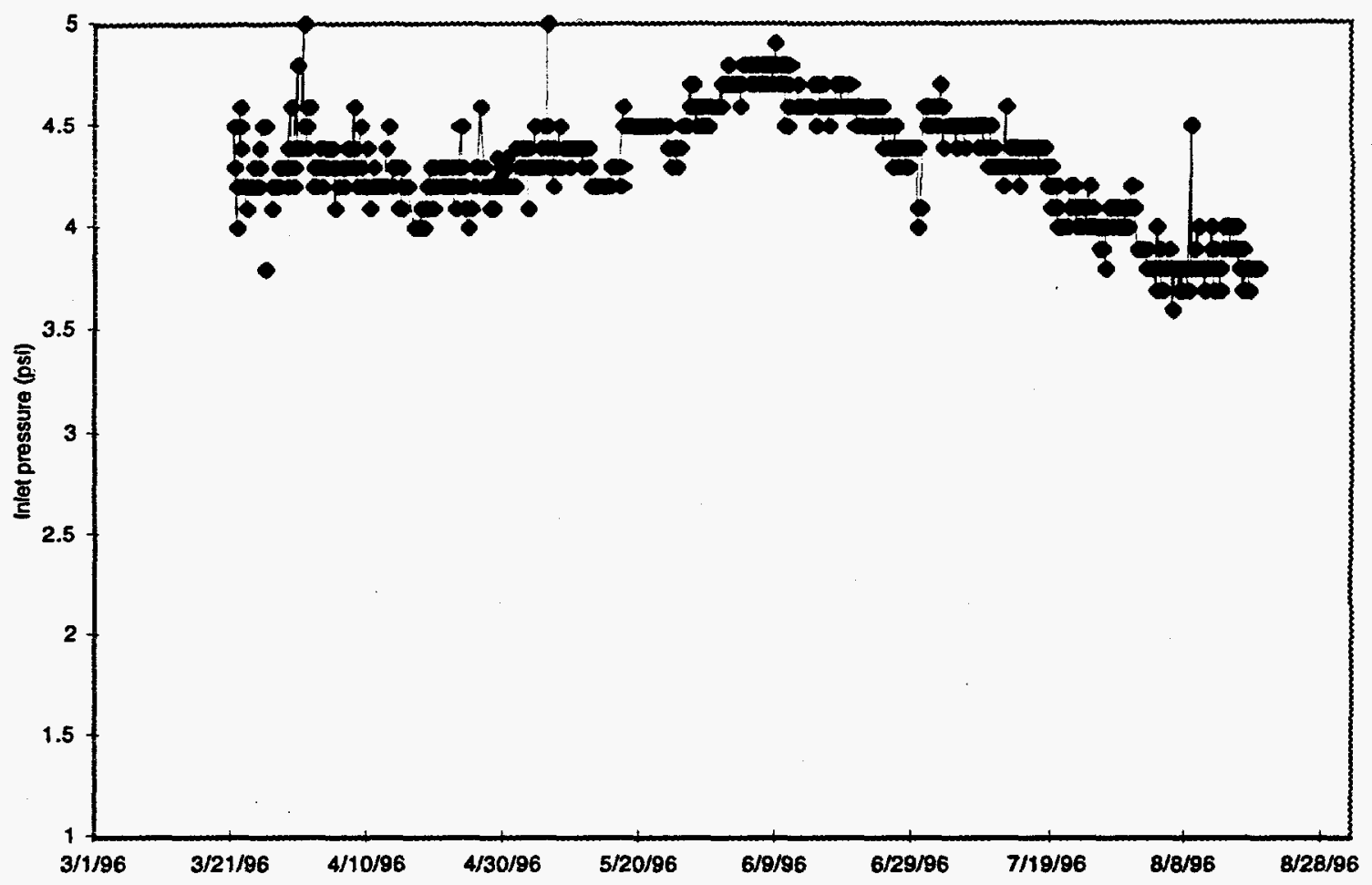

Fig. 1. Inlet pressure at the $\mathrm{X}-725 / \mathrm{X} 120$ treatment facility.

\subsubsection{Treatment Train Configuration}

The system configuration and its components are schematically shown in Fig. 2. Pressure gauges, flow meters, and sampling ports (see Fig. 2) were installed at strategic points along the treatment trains for obtaining process parameters and groundwater samples. Hydrolabs were also placed at the inlet and outlet of each treatment. However, due to concerns regarding instrument fouling as a result of iron oxide precipitation, these Hydrolabs were taken off line shortly after system start-up and are no longer used to monitor the process.

Pretreatment/filter column. Groundwater from the horizontal well enters the building and flows through a filter column ("FC" in Fig. 2). The filter column is constructed from PVC pipe $12 \mathrm{in.} \mathrm{long}$ and $6 \mathrm{in}$. in diameter. The filter column contains a mixture of $50 \%$ sand and $50 \%$ iron filings sandwiched between two layers of fine-grained sand. The filter column was installed to serve two purposes (1) to remove suspended materials and (2) to scavenge the dissolved oxygen (DO) from the groundwater. DO removal was thought to be necessary because the iron filings in the treatment trains would be rapidly oxidized by oxygen present in the groundwater. Subsequent testing has shown, however, that the DO in the water is low and the iron treatment step was not necessary. Due to persistent 
clogging of the filter columns that impeded flow through the treatment system, it was taken off-line permanently on July 30, 1996.

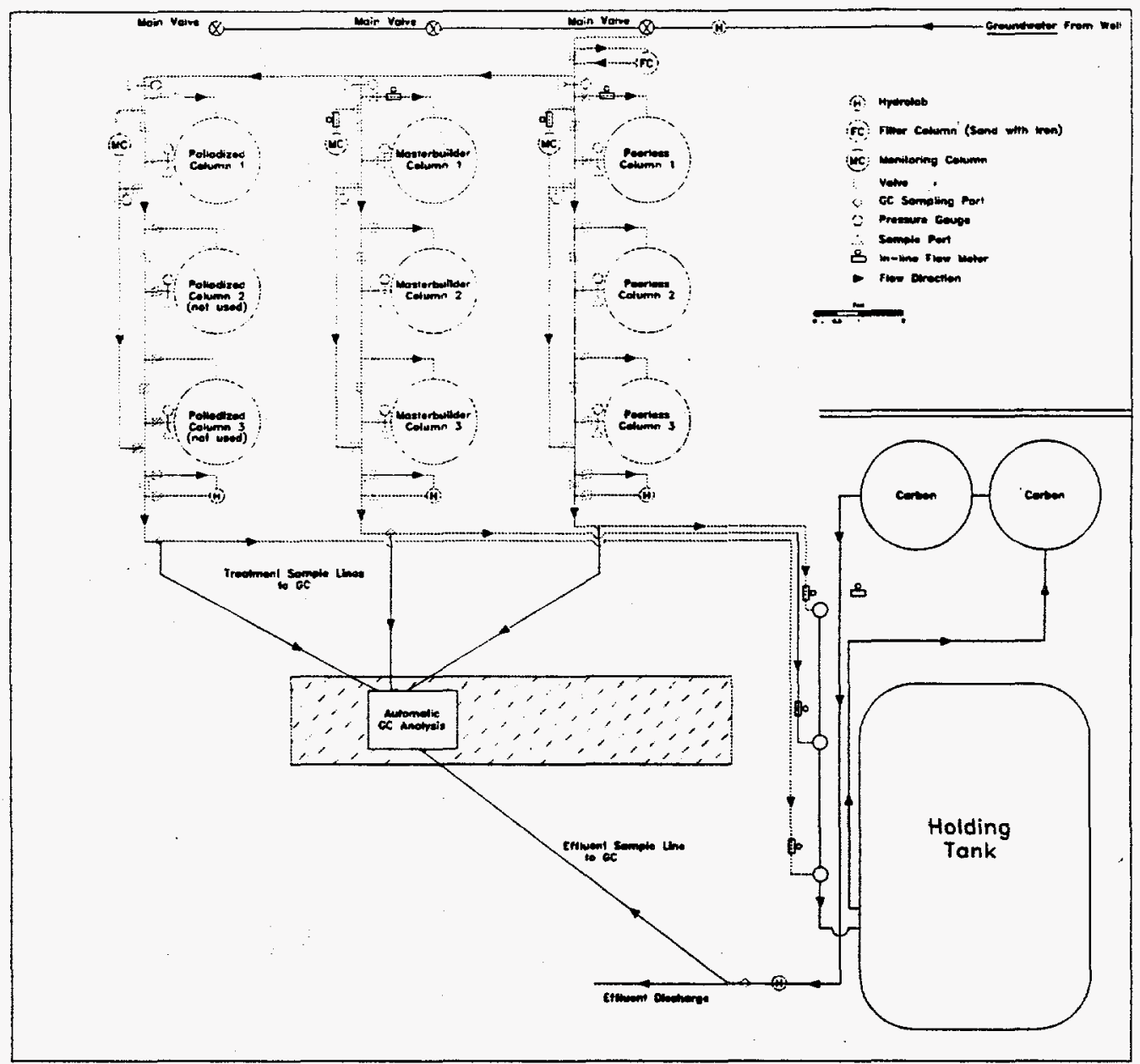

Fig. 2. Schematic of treatment trains in the X-625 Groundwater Treatment Facility. 
Treatment trains and canisters. Following the filter column, groundwater flows into a manifold where it is routed through three parallel treatment trains (Fig. 2). Each train consists of three 55-gal drums connected to a manifold that has valves allowing operation of any number of drums in series. The drums (see Fig. 3) were purchased from LiquidPure and were originally designed for activated carbon applications. However, these drums were readily used without modification to contain iron filings at the X-625 GTF. Groundwater enters the bottom of the drums through a manifold and exits at the top (see Fig. 3).

All three drums in the Master Builders and Peerless treatment trains were wet-packed using PORTS potable water. Sand layers were placed at the inlet and outlet of the drums, and iron filings were sandwiched between the sand layers. The thickness of each layer is depicted in Fig. 4. Only one drum was used in the palladized iron treatment train, with only a 6-in. layer of reactive material (Fig. 5). This depth was thought to be sufficient to reduce influent TCE levels (100 to $200 \mathrm{ppb})$ to below the minimum acceptable level (10 $\mathrm{ppb}$ on the basis of degradation rates measured in laboratory experiments.

Monitoring columns. A monitoring column was designed and installed in parallel with each treatment train to enable the determination of TCE degradation rates and by-product profile distribution in each treatment train (Fig. 6; see Fig. 1 for monitoring column locations). The monitoring columns were constructed with stainless steel and were 6 in. in diameter and $36 \mathrm{in}$. in length. The sampling ports were installed $1 \mathrm{in}$. apart along the length of column (see Fig. 6). The monitoring columns were filled with the same thickness of the treatment media as the corresponding drums.

Post-treatment of groundwater. After passing through the treatment trains, the groundwater flows into a vented 1000-gal holding tank (see Fig. 2). When water in the holding tank reaches a certain level, water is automatically pumped through a series of carbon canisters before it is discharged into DOE Outfall \#12. Following a regulatory guidance document, the effluent from the building is periodically monitored for TCE by a process gas chromatograph (GC) equipped with an autosampler. This ensures that TCE levels prior to discharge are below $10 \mathrm{ppb}$. Integrated effluent from the treatment trains are also being monitored by the process GC.

All manifold lines and valves are made of PVC. Initially, tygon tubing was used where flexible tubing was required for connections. Because of oxygen diffusion through the tygon tubing (which caused significant precipitation of iron oxides), the tygon tubing was subsequently replaced with copper. Following replacement, DO values decreased by approximately a factor of ten. Sample lines for the process GC are made of Teflon. 


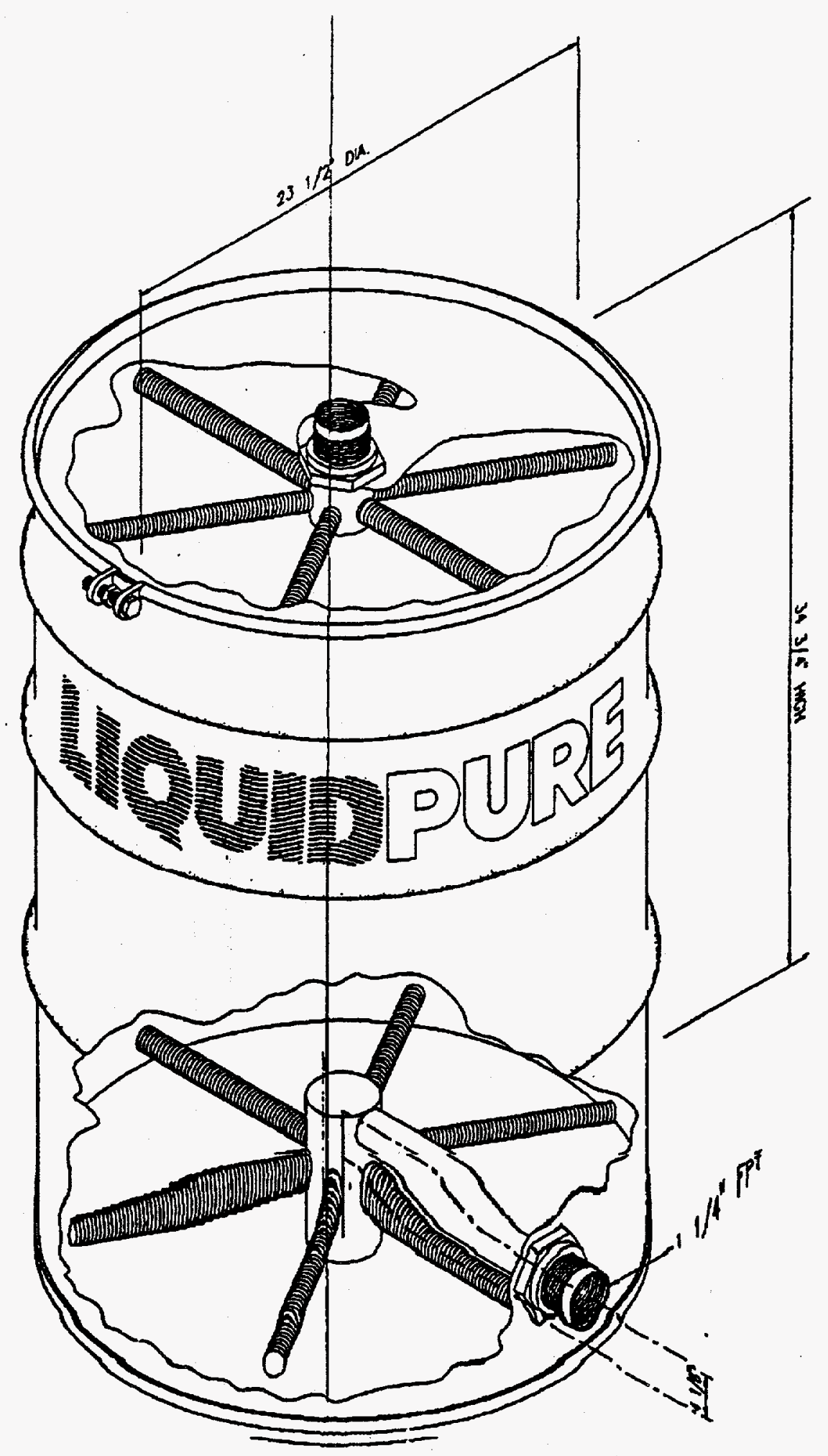

Fig. 3. Drums used for containing reactive materials. 
40-mesh stainless steel screen with glass wool around edge

60-mesh stainless steel screen with glass wool around edge

60-mesh stainless steel screen with glass wool around edge

40-mesh stainless steel screen with glass wool around edge<smiles>C[AlH]C</smiles>

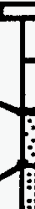

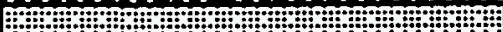
foj

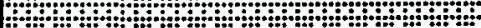
4 H H

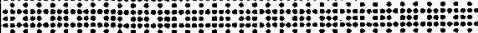
Hofom (1) an ; + ond 促 H: o N

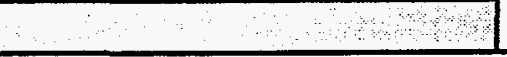

2.0-in. no fill

2.5-in. No. 4 well sand

2.5-in No. 5 well sand

22.0-in. iron filings 2.5-in. No. 5 well sand 2.5-in. No. 4 well sand

Fig. 4. Packing of Master Builders and Peerless iron filings in canisters.

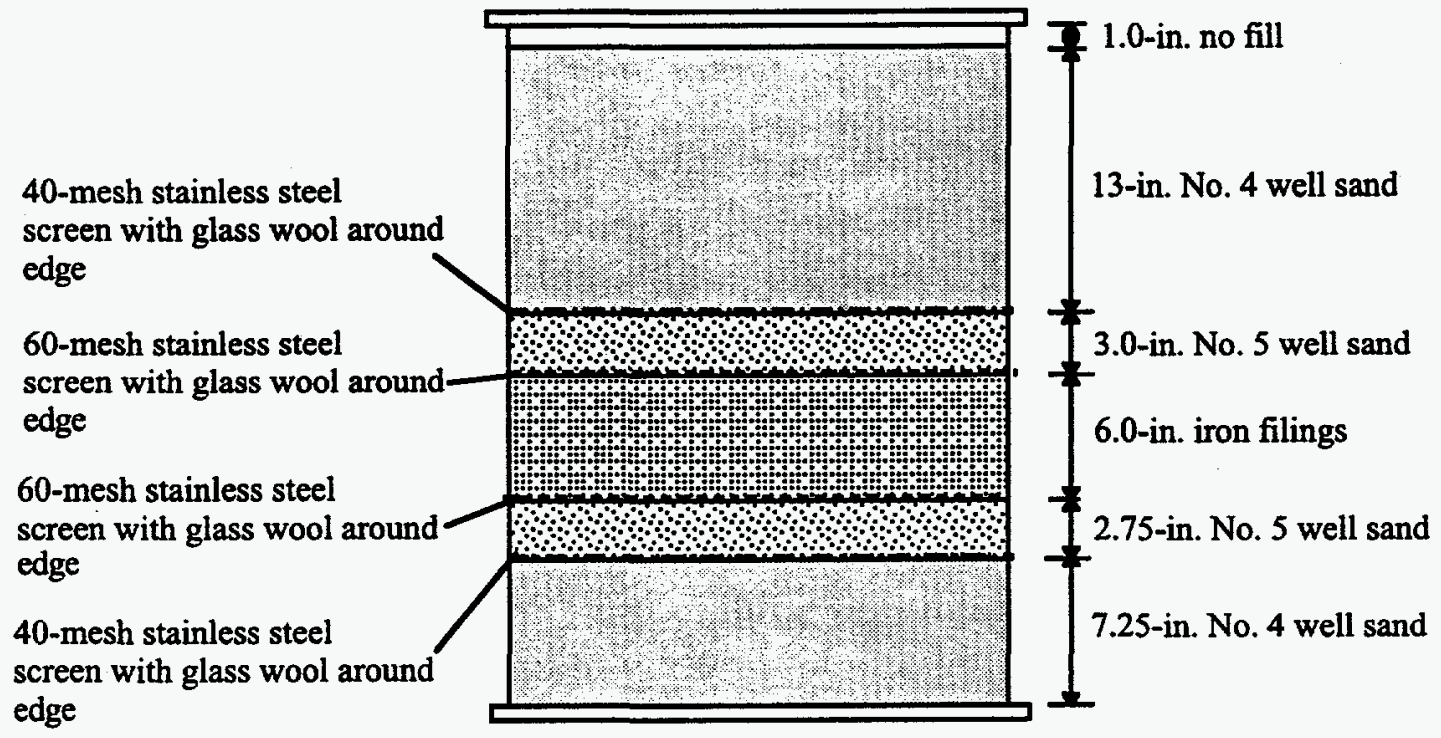

Fig. 5. Packing of palladized iron filings in canisters. 


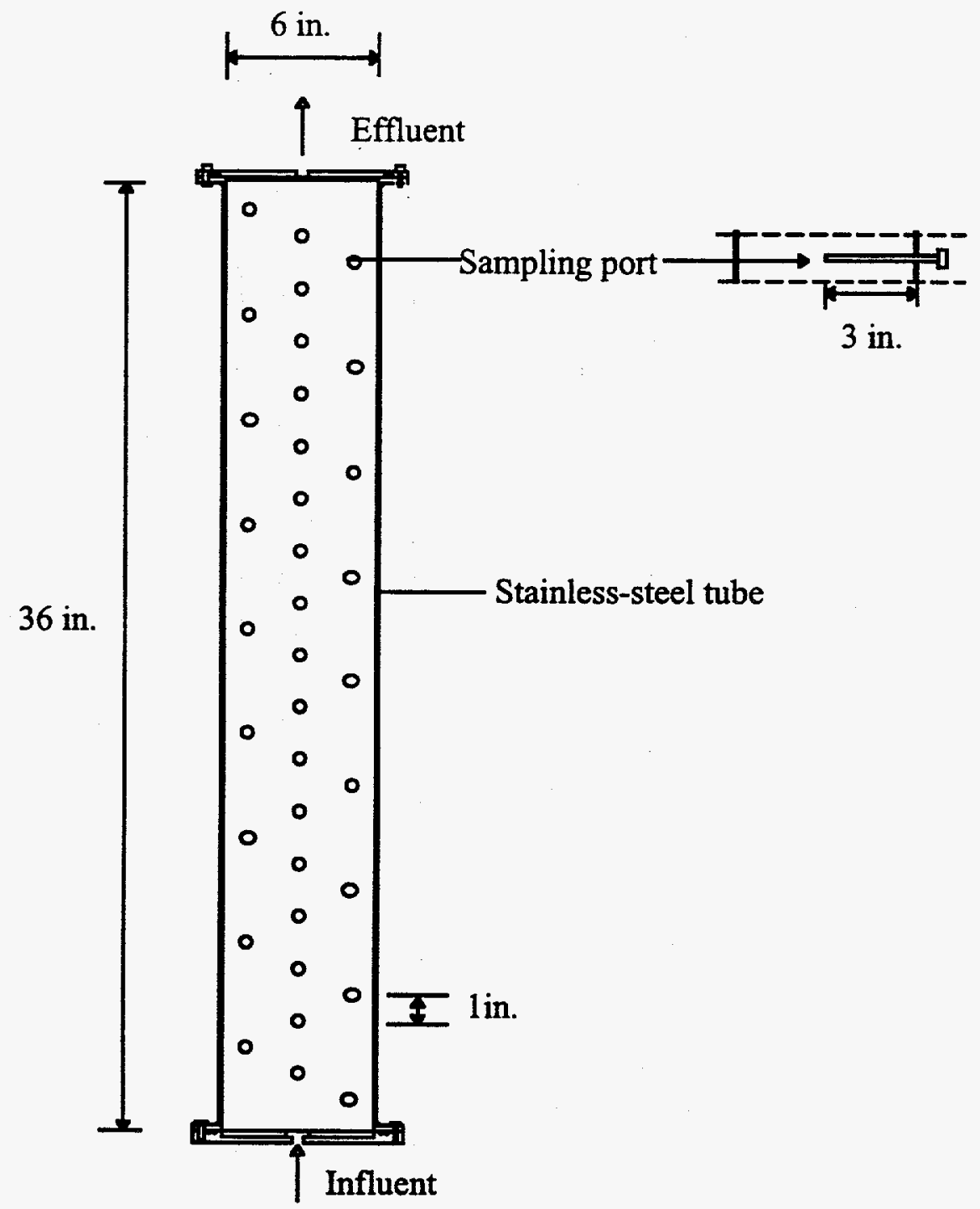

Fig. 6. Monitoring column design. 


\subsection{Start-up Procedures}

As part of the well development process, the horizontal well was jetted with 6000 gal of water. Fifteen to twenty thousand gallons of water were removed from the well by gravity feed during and after jetting. When the horizontal well was connected to the treatment system, groundwater turbidity was less than 10 NTU.

The following is a chronology of the steps taken to start the system and transfer it to PORTS personnel for routine use. The discussion below focuses on the tasks performed by ORNL-GJ personnel and provides highlights of the major observations. Improvements of the system were made following discussions among personnel from ORNL and PORTS.

November/December 1995. The water distribution manifolds for directing the groundwater to the treatment canisters were assembled (Fig. 2). Manifolds were leakchecked with potable water.

February 1996. The monitoring columns and drums were assembled. The monitoring columns were leak-checked with $10 \mathrm{psi}$ air before installation on the treatment train. The rest of the system was checked for leaks after it was hooked up to the horizontal well. By the end of the month, groundwater was run into the building although not through the treatment trains.

March 1-2, 1996. The drums and monitoring columns were wet-packed with treatment media using potable water from the plant. The filter column was also wet-packed with a 50:50 mixture of sand and iron filings.

March 3-25, 1996. Groundwater was directed to the treatment system. Leaks, mostly around the filter column, were repaired. During the start-up period, flow through the treatment trains was unstable. However, problems with the system were identified and immediately resolved (see Table 1). After implementation of the solutions described in Table 1, flows were relatively stable and operation of the facility was transferred to PORTS personnel on March 26. 
Table 1. Problems encountered and solutions implemented during the start-up of the X625 Groundwater Treatment Facility

\begin{tabular}{|l|l|}
\hline Start-Up Problem & Solution \\
\hline $\begin{array}{l}\text { Large pressure drops occurred across } \\
\text { initially installed flow meters in monitoring } \\
\text { column and effluent lines. }\end{array}$ & $\begin{array}{l}\text { Flow meters on effluent lines were replaced } \\
\text { with meters designed for low flow rates; } \\
\text { flow meters on monitoring columns were } \\
\text { replaced with low-pressure drop variable- } \\
\text { area rotameters. Needle valves on the } \\
\text { monitoring column influent lines were } \\
\text { removed; ball valves were installed on the } \\
\text { monitoring column effluent lines to control } \\
\text { flow. }\end{array}$ \\
\hline $\begin{array}{l}\text { Gas (most likely } \mathrm{H}_{2} \text { ) was building up in } \\
\text { drums, monitoring } \\
\text { distribution manifolds. }\end{array}$ & $\begin{array}{l}\text { Stand pipes with pressure release valves on } \\
\text { the ends were installed on drums (March } \\
26, \text { 1996) to enable manual venting of } \\
\text { accumulated gas. The manifolds were } \\
\text { elevated in relation to the tops of drums } \\
\text { and monitoring columns to facilitate gas } \\
\text { flow through the system. Drums are now } \\
\text { routinely vented; the building atmosphere } \\
\text { is regularly monitored for hydrogen gas. }\end{array}$ \\
\hline $\begin{array}{l}\text { Heavy precipitation was observed in tygon } \\
\text { tubing. Precipitates were believed to be } \\
\text { iron oxides formed by the reaction of } \\
\text { ferrous iron with the oxygen diffused } \\
\text { through the tygon tubing. }\end{array}$ & Tygon tubing was replaced with copper. \\
\hline $\begin{array}{l}\text { Outside vent of holding tank was blocked } \\
\text { flow stoppage in the system. }\end{array}$ & $\begin{array}{l}\text { The vent screen was removed because it } \\
\text { was trapping condensate, which was } \\
\text { subsequently freezing at low temperatures. }\end{array}$ \\
\hline
\end{tabular}




\subsection{Process Monitoring and Sample Analysis}

Pressure, flow rates, volatile organic compound (VOC) concentrations and basic water chemistry parameters $(\mathrm{pH}$, dissolved oxygen (DO), ferrous iron [ $\mathrm{Fe}(\mathrm{II})]$, alkalinity, and turbidity) were monitored periodically at the X-625 GTF. Sulfate and sulfide were also analyzed at selected sampling ports. Pressures along the treatment trains (see Fig. 1 for pressure gauge locations) and flow rates (through the monitoring columns and treatment trains) were recorded four to six times daily.

Duplicate samples for VOC analyses were collected at the influent sampling port (before the filter column), at the sampling ports between drums, and at the effluent lines. These samples were sent to ORNL-TN for analysis. Selected VOC samples were sent to the PORTS analytical laboratory to compare them with and verify the VOC analysis at ORNL. The water samples were collected and stored without headspace in 20-mL or 40$\mathrm{mL}$ glass vials with Teflon/silicone-lined caps. Samples were transported to analytical laboratories in coolers packed with blue ice. These were subsequently stored at $4^{\circ} \mathrm{C}$ until analysis.

VOC analysis at ORNL was conducted on a gas chromatograph equipped with purgeand-trap extractor and a flame ionization detector. This instrument was calibrated for TCE, cis-1,2-dichloroethene (DCE), 1,1-dichloroethene, vinyl chloride (VC), and ethane. VOC analysis at the PORTS analytical laboratory was conducted following EPA Method SW846-8260A.

The water chemistry parameters were immediately analyzed on-site after sample collection. DO and $\mathrm{Fe}$ (II) were measured by colorimetric techniques using test kits from Hach. Alkalinity was determined by titration. Turbidity was analyzed with light scattering techniques and $\mathrm{pH}$ was measured by electrodes. Care was taken to conduct the analyses as soon as the samples were collected to avoid measurement errors created by the exposure of the samples to the atmosphere.

\subsection{System Hydraulics}

Treatment Train with Master Builders Iron. Efforts were made to maintain a flow of at least $0.3 \mathrm{gpm}$ through each of the treatment trains. During the start-up phase, flow through the Master Builders train was erratic due to gas build-up in the canisters (Fig. 7). The gas contained hydrogen generated by the reductive dissociation of water with the zero-valence iron. This was confirmed by the analysis of a 2-L gas sample accumulated more than a day from one of the off-line canisters with Master Builders filings. This sample contained $22.3 \% \mathrm{H}_{2}, 4.2 \% \mathrm{O}_{2}, 0.05 \% \mathrm{CO}_{2}, 0.01 \%$ methane. Gas bubbles were observed in all three treatment trains; however, gas build-up was most severe in the Master Builder canisters most likely as a result of the relatively small size of the iron filings (40-mesh in comparison with a maximum of 8-mesh in the Peerless train). The 
palladized iron filings were also 40-mesh but with much less quantity -only 6 in. of this material while the rest of the canister was filled with coarse sand (see Fig. 5). Generated gas was flowing more easily through the Peerless and $\mathrm{Pd} / \mathrm{Fe}$ canisters.

The canisters were vented through valves located on the tops of the canisters. Thus, only accumulated gas within the top of the canisters was released, leaving behind gas trapped within the pore spaces of iron layers. During the first weeks of operation, the Master Builder treatment train required daily venting to maintain flow while the Peerless and $\mathrm{Pd} / \mathrm{Fe}$ trains were vented less frequently. After approximately 1 month of operation, gas generation appeared to have decreased in the Master Builders train and required less frequent venting. However, after approximately 2 months, flow through the Master Builder train started to decrease despite efforts to release gas from the canisters (see flow after about May 20, 1996 in Fig. 7). The first Master Builder canister appeared to be clogged and the Master Builder train's flowmeter was plugged with black scale; flows increased after the first canister was taken off-line and the flowmeter was replaced. Flow in the Master Builders train with the two remaining canisters was stable for approximately 1.5 months until it started to decrease again through the first part of July (see Fig. 7). Similar to the first canister, venting the second canister from the top did not help improve flow. On July 31 , flow increased from $<0.1 \mathrm{gpm}$ to $0.3 \mathrm{gpm}$ after the bypass valve for the second canister was cracked open. Because flows started to decrease again soon after, it was decided to shut down the Master Builders treatment train on August 13.

Peerless Iron. Flow through the Peerless treatment train has been relatively stable in comparison with that in the Master Builders train. Venting the canisters was usually sufficient to increase flows back to $>0.3 \mathrm{gpm}$. In August, after approximately 5 months of operation, there appeared to be a decreasing trend in flow through the Peerless treatment train (see Fig. 8). Venting of the canisters still improved flow although less effectively than it did during the first months of operation.

Palladized Iron. Flow through the $\mathrm{Pd} / \mathrm{Fe}$ treatment train was stable through the first month of operation, after which flows started to decline (see Fig. 9, after April 10, 1996) and venting was no longer effective in increasing flows through the train. Flows increased again after the train was valved off and immediately put back on-line on May 10 (see Fig. 9). The $\mathrm{Pd} / \mathrm{Fe}$ treatment train was taken off-line on May 17 after breakthrough of TCE was measured in the effluent (see Sect. 3.1). The breakthrough indicated that the performance of the $\mathrm{Pd} / \mathrm{Fe}$ filings had deteriorated. On July 18 , the $\mathrm{Pd} / \mathrm{Fe}$ treatment train was put back on-line. Flows were stable for approximately 1 month at which point flows began to decline steadily. 


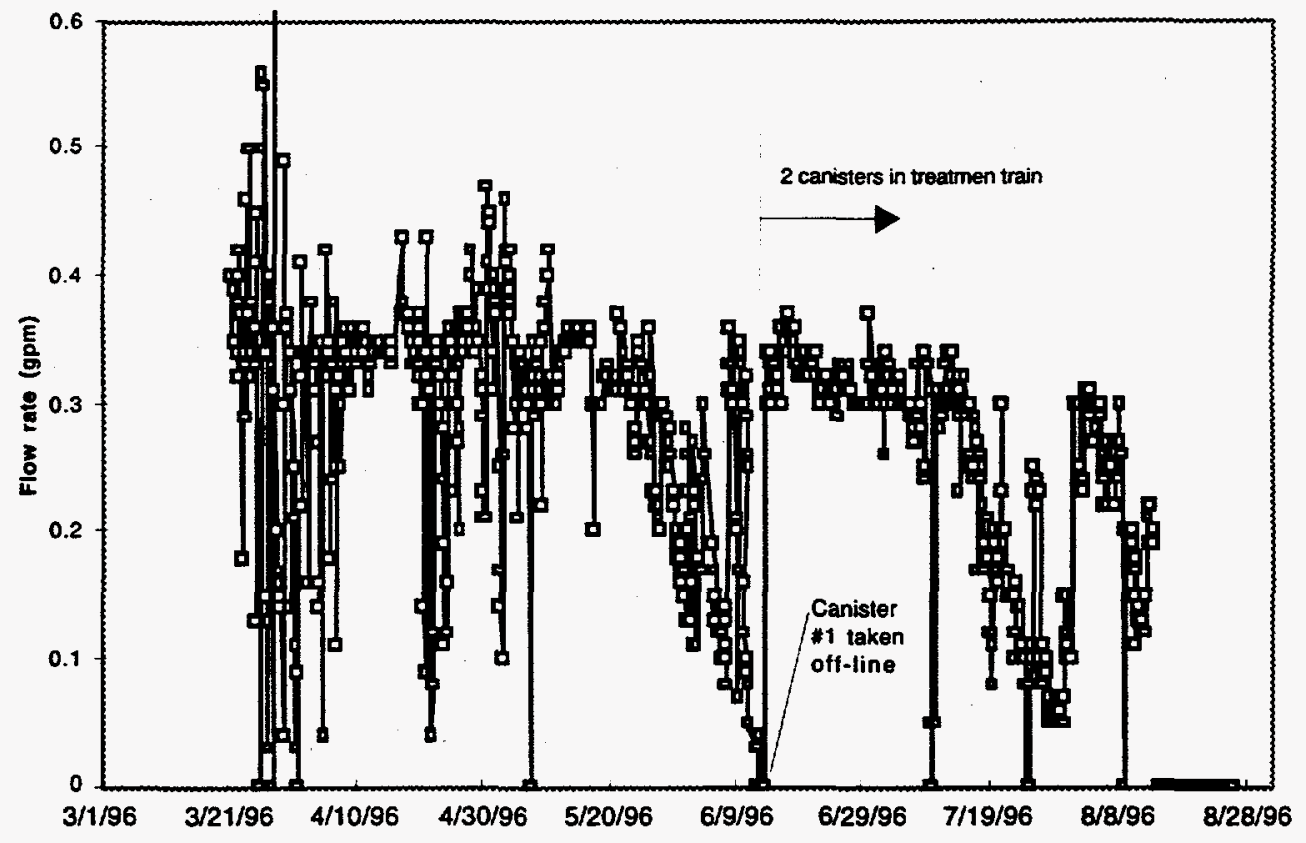

Fig. 7. Measured flow rates through the Master Builders treatment train.

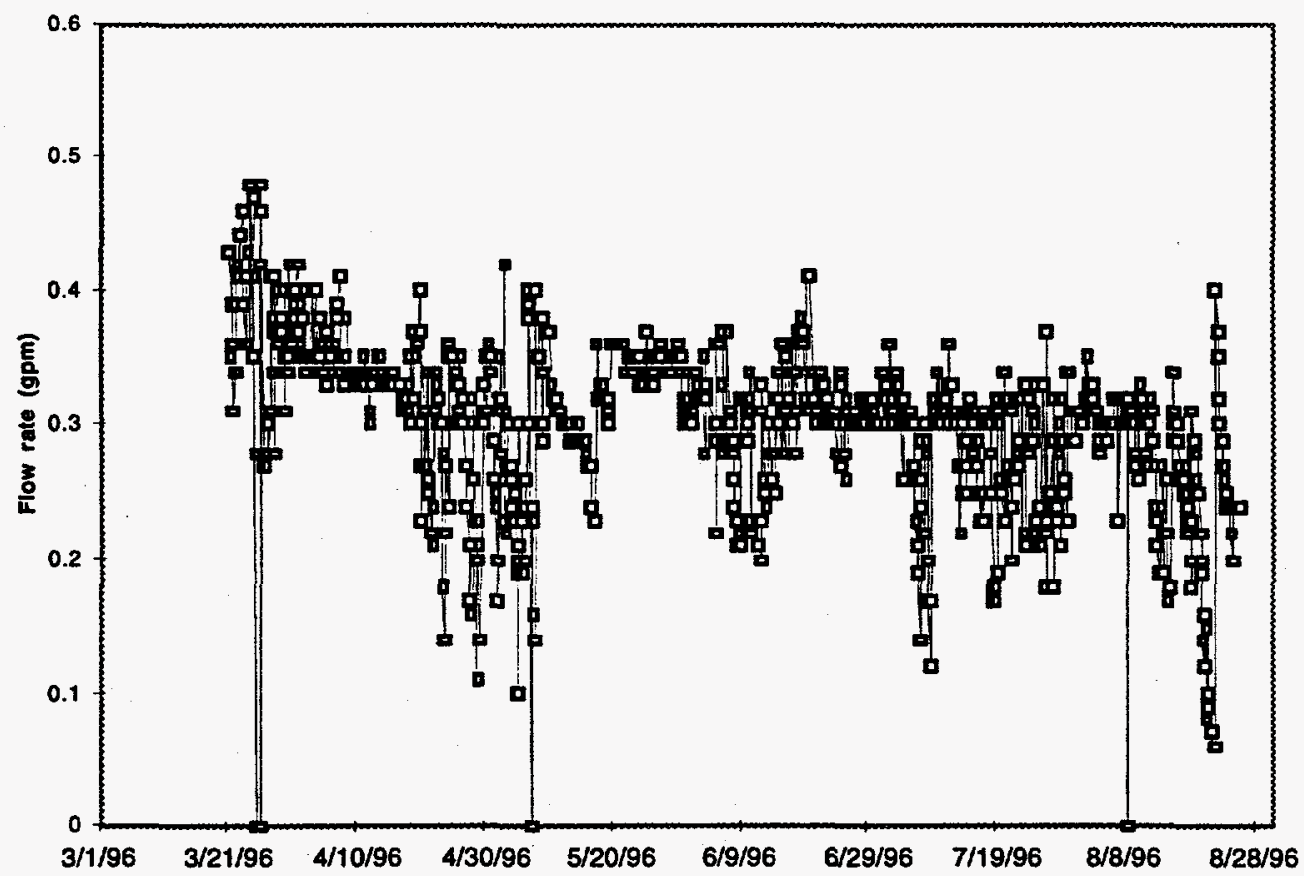

Fig. 8. Measured flow rate through the Peerless treatment train. 


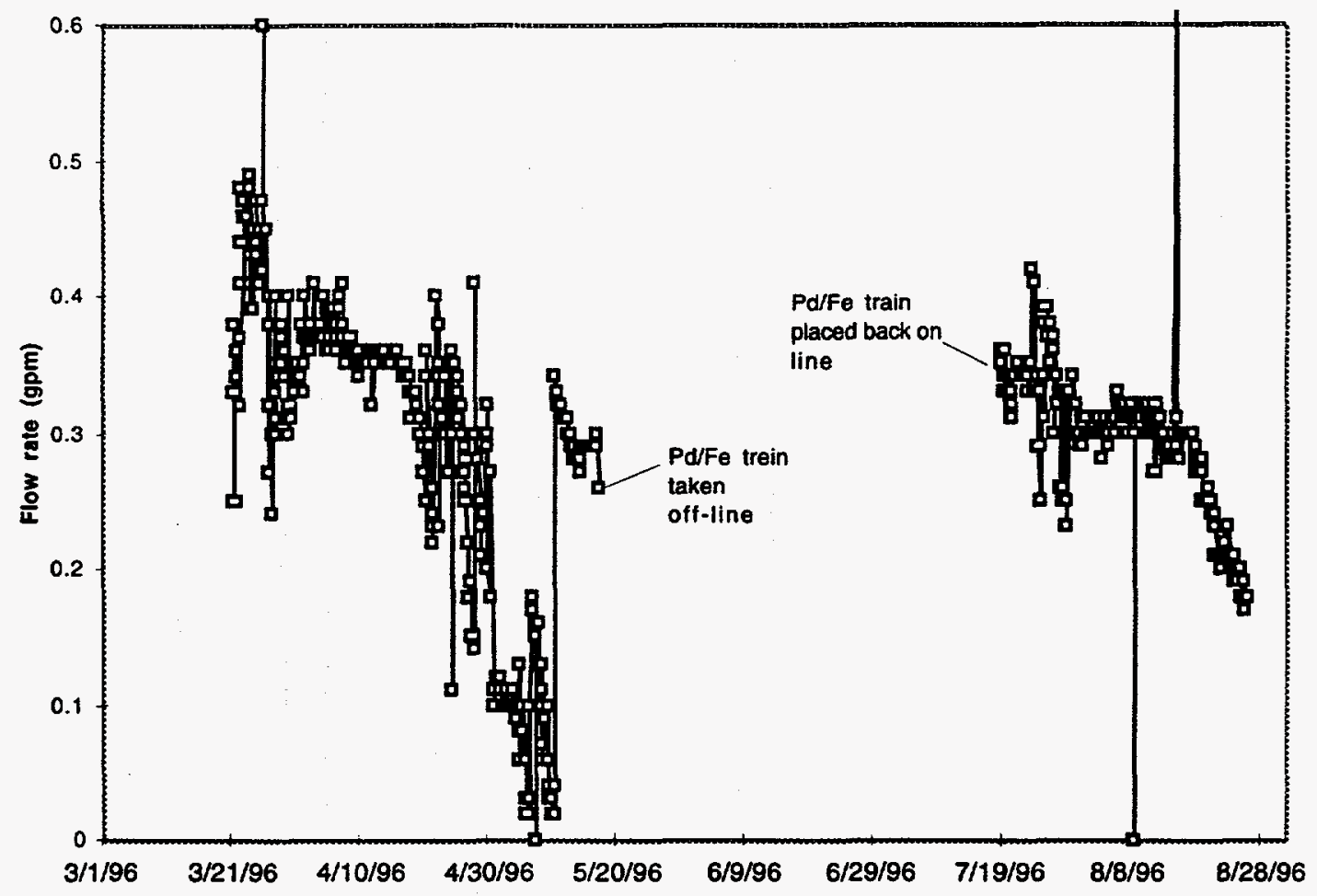

Fig. 9. Measured flow rates through palladized iron treatment train.

The ratio between flow rate and pressure drop $(\mathrm{Q} / \Delta \mathrm{P})$ across a canister can be used as an indicator of the hydraulic conductivity of the material within the canister (see Figs. 10, 11 and 12 for Master Builders, Peerless, and $\mathrm{Pd} / \mathrm{Fe}$ treatment trains, respectively). This ratio was erratic for all three treatment trains during the first month of operation. At that point, regular venting of the canisters had not been implemented as a standard maintenance protocol. In the Master Builders canister, $\mathrm{Q} / \Delta \mathrm{P}$ started to decline steadily during the first part of May (see Fig. 10). At the same time, flow rates were decreasing and venting could not bring flows back to $0.3 \mathrm{gpm}$ (see previous discussion). These observations are consistent with the assumption that canister no. 1 of the Master Builders train had clogged up.

The $\mathrm{Q} / \Delta \mathrm{P}$ ratio for the Peerless train has also been decreasing, albeit more gradually than the Master Builder treatment train (Fig. 11). In the $P d / F e$ train, the $Q / \Delta P$ ratio decreased markedly after one month of operation (see Fig. 12) but increased again after May 10 when the canister was taken off and put back on-line (corresponding to when flows increased from $<0.1 \mathrm{gpm}$ to $0.3 \mathrm{gpm}$, see Fig. 9). The $\mathrm{Q} / \Delta \mathrm{P}$ ratio was high when the $\mathrm{Pd} / \mathrm{Fe}$ train was put back on-line on July 18 after being off-line for approximately 2 months. After approximately 0.5 month, the $\mathrm{Q} / \Delta \mathrm{P}$ ratio started to decline steadily, corresponding to decreasing flow in the Pd/Fe train (see Fig. 9). 
Total flows in terms of pore volumes have been highest for the palladized iron treatment train (see Table 2). In terms of actual volumes, the Peerless train has treated the largest volume of groundwater. Total flow through the Master Builder train is lower because its flow has been more erratic due to gas build-up.

Table 2. Summary of significant events and total volumes of groundwater passing through treatment trains

\begin{tabular}{|c|c|c|c|c|c|c|c|c|}
\hline \multirow[b]{2}{*}{ Date } & \multirow[b]{2}{*}{$\begin{array}{l}\text { Run } \\
\text { time } \\
\text { (days) }\end{array}$} & \multirow[b]{2}{*}{ Remarks } & \multicolumn{3}{|c|}{$\begin{array}{l}\text { Cumulative volume of water } \\
\text { (gallons) }\end{array}$} & \multicolumn{3}{|c|}{ Cumulative pore volumes of water $b$} \\
\hline & & & $\begin{array}{l}\text { Palladized } \\
\text { iron }\end{array}$ & $\begin{array}{l}\text { Master } \\
\text { Builders }\end{array}$ & Peerless & $\begin{array}{l}\text { Palladized } \\
\text { iron }\end{array}$ & $\begin{array}{l}\text { Master } \\
\text { Builders }\end{array}$ & Peerless \\
\hline $03 / 05 / 96$ & & Start of test & & & & & & \\
\hline $03 / 06 / 96$ & 1 & Sampling & & & & & & \\
\hline $03 / 12 / 96$ & 7 & Sampling & & & & & & \\
\hline $03 / 28 / 96$ & 23 & Sampling & 12963 & 7916 & 11203 & 1826 & 102 & 144 \\
\hline $04 / 11 / 96$ & 37 & Sampling & 20277 & 13281 & 18352 & 2856 & 171 & 236 \\
\hline $04 / 23 / 96$ & 49 & Sampling & 26050 & 18774 & 23907 & 3669 & 242 & 308 \\
\hline $05 / 07 / 96$ & 63 & Sampling & 29747 & 25328 & 29389 & 4190 & 326 & 379 \\
\hline $05 / 17 / 96$ & 73 & $\begin{array}{l}\text { Palladized iron } \\
\text { train off-line }\end{array}$ & 32996 & 30318 & 33856 & 4647 & 391 & 436 \\
\hline $05 / 28 / 96$ & 84 & Sampling & $\mathrm{O} / \mathrm{S}^{c}$ & 35694 & 39296 & & 460 & 506 \\
\hline $06 / 06 / 96$ & 93 & Sampling & O/S & 37700 & 43600 & & 486 & 562 \\
\hline $06 / 07 / 96$ & 106 & $\begin{array}{l}\text { Master Builder } \\
\text { canister } 1 \text { off-line }\end{array}$ & $\mathrm{O} / \mathrm{s}$ & 37900 & 44000 & & 488 & 567 \\
\hline $06 / 19 / 96$ & 126 & Sampling & $\mathrm{O} / \mathrm{S}$ & 42586 & 49145 & & 579 & 633 \\
\hline $07 / 09196$ & 128 & Sampling & O/s & 51043 & 57749 & & 742 & 744 \\
\hline $07 / 18 / 96$ & 135 & $\begin{array}{l}\text { Sampling; } \\
\text { palladized iron } \\
\text { train back on-line }\end{array}$ & 32996 & 58764 & 61490 & 4647 & 891 & 792 \\
\hline $07 / 31 / 96$ & 148 & $\begin{array}{l}\text { Sampling, Filter } \\
\text { column off-line }\end{array}$ & 39166 & 61184 & 66390 & 5516 & 938 & 856 \\
\hline $08 / 7 / 96$ & 155 & Sampling & 42218 & 63854 & 69429 & 5946 & 989 & 895 \\
\hline $08 / 20 / 96$ & 168 & Sampling & & & & & & \\
\hline
\end{tabular}

a Volumes obtained from flow integrators installed on each treatment train.

${ }^{b}$ Calculated using pore volumes of 77.6 gal for Master Builders and Peerless treatment trains and 7.1 gal for palladized iron treatment train. Porosity of packed canisters assumed to be $60 \%$.

${ }^{c} \mathrm{O} / \mathrm{S}$ - out of service. 


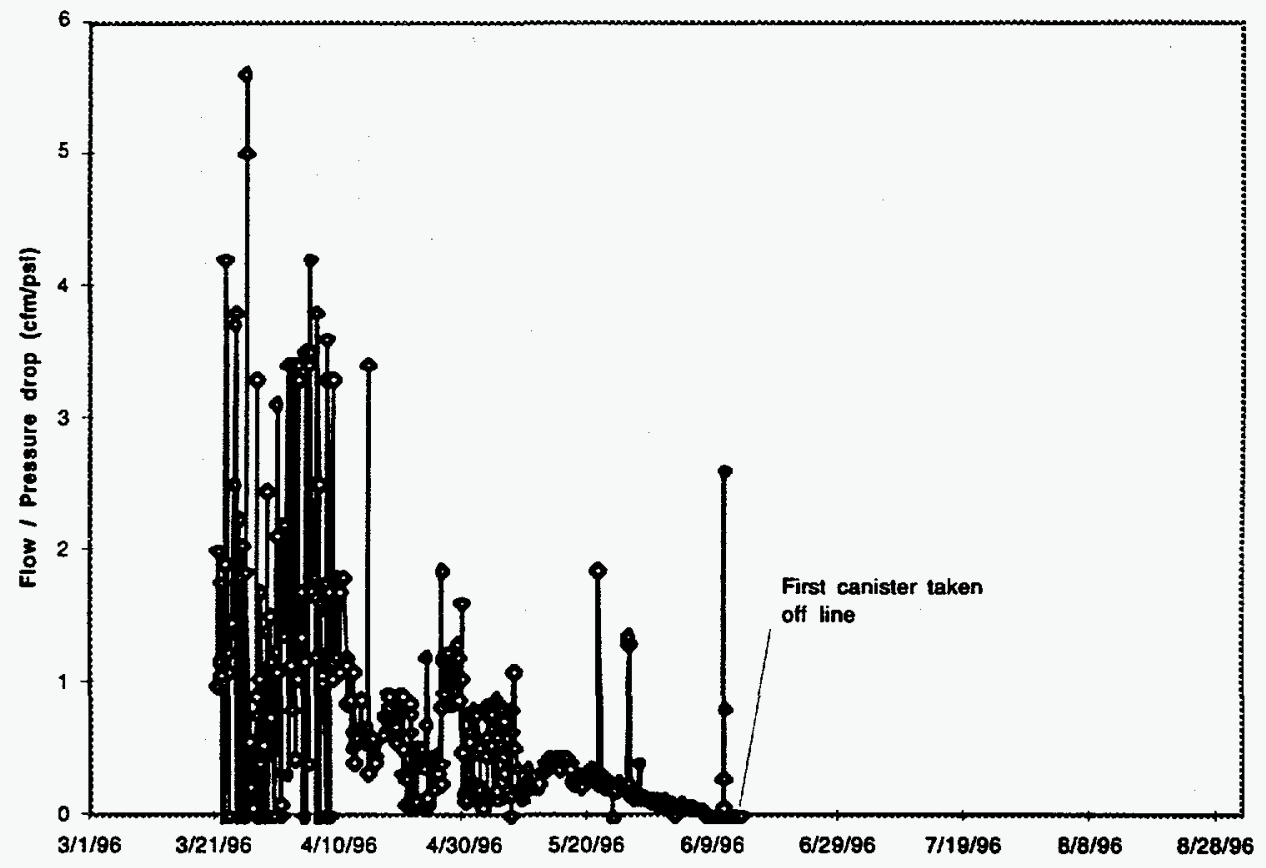

Fig. 10. Ratio between flow and pressure drop across the first canister in the Master Builders treatment train.



Fig. 11. Ratio between flow and pressure drop across the first canister in the Peerless treatment train. 


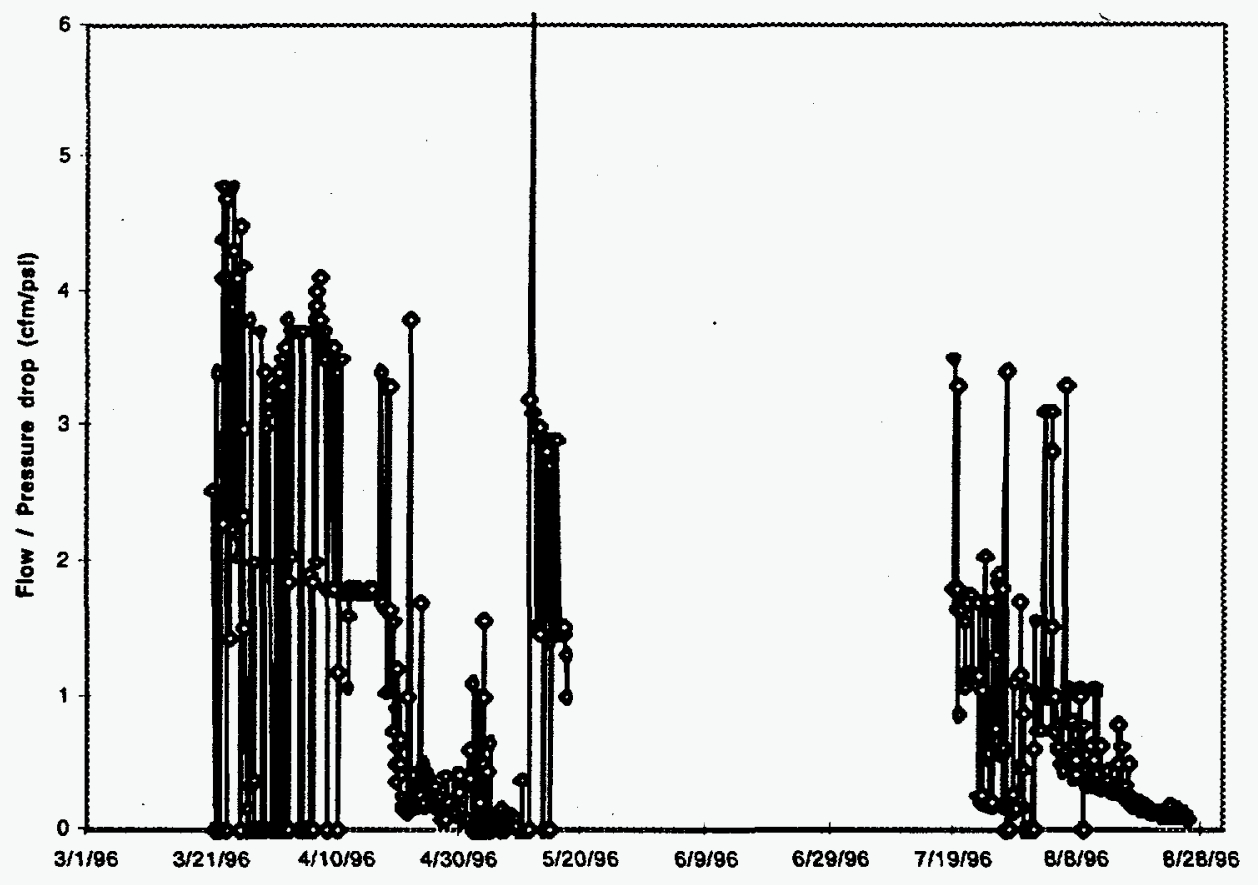

Fig. 12. Ratio between flow and pressure drop across the first canister in the palladized iron treatment train.

\subsection{Observations Regarding System Operation}

\subsubsection{Clogging of Filter Column}

Before it was taken off-line in July, the filter column was constantly clogged and required regular maintenance to sustain adequate flows through the treatment trains. The clogging was believed to be from biomass build-up as slimy materials were observed on the inlet screen and packing material of the filter column. Maintenance of the filter column consisted of backwashing or replacing the filter material whenever pressure drops across the filter column were high. Since the filter column was to remove DO, and the DO levels in the inlet groundwater were low, the filter column was deemed unnecessary and was permanently taken off-line on July 30 .

The biomass observed on the filter column probably consists of sulfate-reducing bacteria growing on the relatively high sulfate of the PORTS groundwater. Sulfate-reducing bacteria were detected in the water samples collected from the treatment trains as well as in the iron filings collected from the canisters. Bacteria build-up was also possible in the 
canisters; a greenish slime was observed on the top surface of some of the treatment canisters.

\subsubsection{Gas Build-Up and Canister Clogging}

As noted in Sect. 2.4, gas build-up in the canisters caused flow stoppage in the treatment trains, particularly with the Master Builder filings. The gas contained hydrogen generated by the reductive dissociation of water with the zero-valence iron. If the inlet hydraulic pressure were higher (e.g., if the groundwater were pumped into the system), the generated gas would be forced out of the treatment trains. Such gas build-up was observed in laboratory experiments when a positive-displacement piston pump, capable of handling backpressures on the order of $100 \mathrm{psi}$, was used to force water through packed iron columns.

During the first month of operation, opening the vent valves on top of the canisters was sufficient to maintain flow through the treatment trains. As time progressed, canister venting in the Master Builder train did not improve the flow rate. Because of large pressure drops and low flow through the Master Builder train, it was assumed that canister 1 was clogged and was then taken off-line.

To determine the cause of this apparent clogging, the material inside the Master Builder canister 1 and 2 was inspected for precipitation (including rust) or biomass build-up when the system was taken off-line. Discoloration by iron oxide was not observed on the filings. The filings were dark black in color and did not have the metallic sheen of unused material. It was observed that the iron filings had aggregated, forming a cohesive material that required a hammer and chisel to break up (see Fig. 13). A similar type of cementation was observed in canister no. 1 of the Peerless train and in the monitoring column of the palladized iron train. However, the aggregated filings were easier to crumble by hand in the Peerless canister. Cementation is likely a result of precipitation of iron sulfides, hydroxides and carbonates. Verification of the presence of these species was attempted by X-ray diffraction analysis of the used iron filings; this proved to be difficult since the mass percentage of iron minerals was orders of magnitude lower than zero-valence iron.

The apparent clogging of the Master Builders train is attributed to the cementation of the iron filings, which decreases the permeability of the canister material and makes it difficult for water to pass through without significant head losses. Furthermore, the cementation of the iron filings reduced the gas flow through the media, forming gas pockets within the bulk-material, thereby reducing pore spaces available for water flow. Under these conditions, the apparent hydraulic conductivity of the canister is further reduced, and venting the top of the canisters would not improve flow. A reduction in hydraulic conductivity as a result of entrapped gas can be reversible. This may be the case for the 
$\mathrm{Pd} / \mathrm{Fe}$ train in which flow increased after the canister was taken off-line and put back online on May 10 (see Fig. 9). Shutting off water flow through the canister may have allowed the entrapped gas to migrate towards the top of the canister, where it was later flushed out when flow was resumed.

The difficulties in maintaining long-term, stable flow through the X-625 system can possibly also occur with in-ground reactive barriers made from the same materials used in this study. Based on the operational observations at the X-625 facility, reactive barriers must be designed in such a way that generated gases can easily be released from the barrier material. This can be achieved by leaving the tops of the barriers exposed to the atmosphere (e.g., not paving over the barriers) and by choosing relatively coarse-grained barrier materials. Mixing iron filings with sand is a means for improving the permeability of the reactive barrier, as long as the iron:sand ratio is sufficient so as not to decrease contaminant degradation rates.

The apparent reduction in permeability and aggregation of the barrier materials tested in the X-120 facility also brings to question the current belief that reactive barriers made from iron filings, once installed, do not require any maintenance and can be left in place without deterioration in performance. Given the observations in this study, it is clear that this assumption of an "indefinite" design life for a reactive barrier, particularly at PORTS must be reassessed.

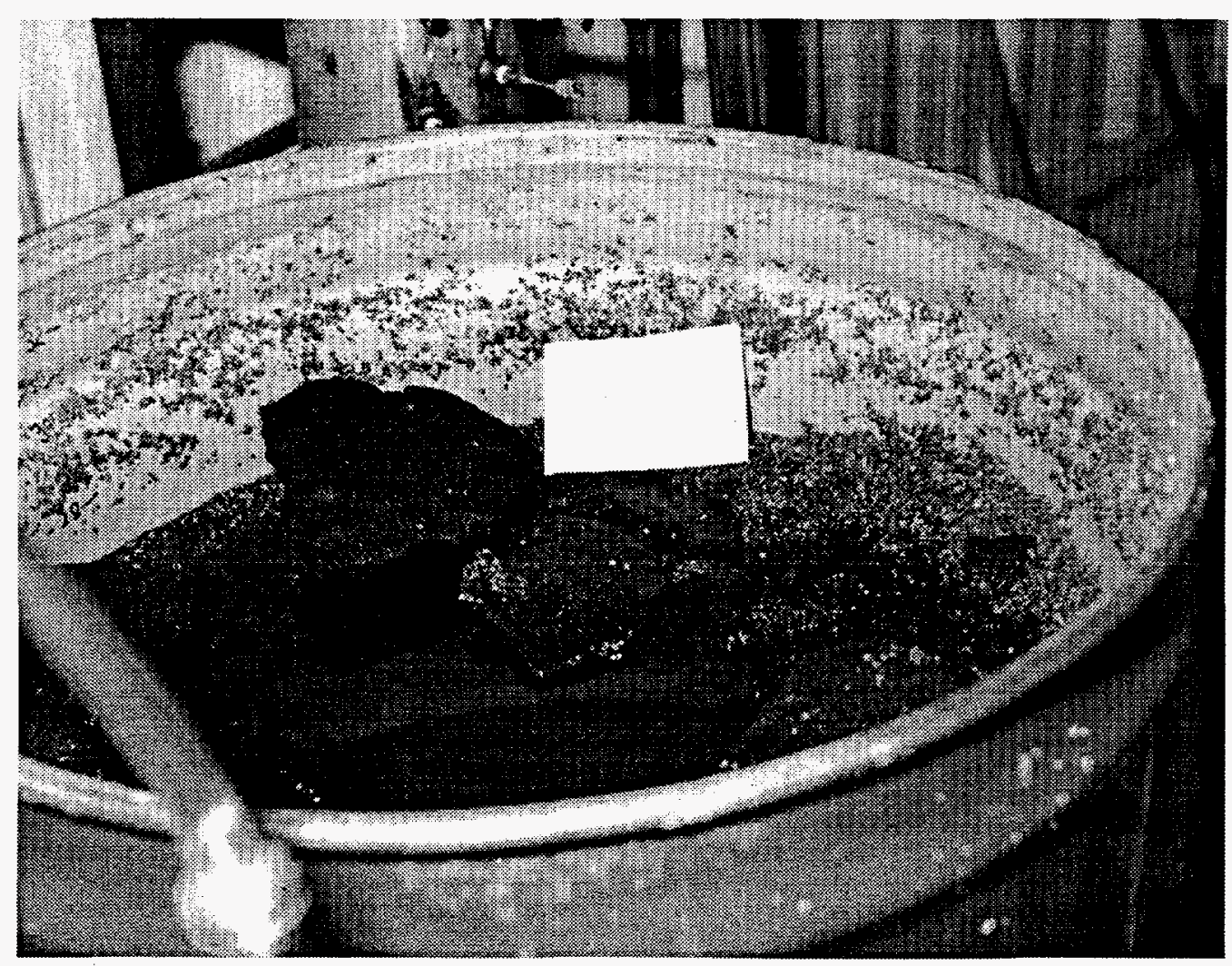

Fig. 13. Photograph of cemented filings from Master Builders canister. 


\subsubsection{Iron Oxide Precipitation}

Elevated ferrous iron concentrations have been measured in effluents from all three treatment trains (see Sect. 3). These high concentrations led to significant iron oxide precipitation due to oxygen diffusing through the tygon tubing. This precipitation was reduced when the tygon tubing was replaced with copper. For reactive barriers constructed in situ, iron oxide precipitation may not pose a problem if the water remains anoxic as it flows past the reactive barrier. However, if zero-valence iron is to be used for above-ground applications (e.g., to replace activated carbon canisters in pump-and-treat systems), uncontrolled iron precipitation may cause clogging of water lines. To prevent such problems, $\mathrm{Fe}^{2+}$ must be controlled in above-ground zero-valence iron treatment systems. 


\subsection{VOC DEGRADATION AND CHANGES IN WATER CHEMISTRY ALONG THE TREATMENT TRAINS}

\subsection{VOC Degradation}

Fourteen sampling events were performed between system start-up and August 20, 1996. Samples were sent to both ORNL and PORTS for volatile organic compound analysis. In general, both analytical labs produced nearly identical results for TCE and cis-1,2-DCE. 1,1-DCE and trans-1,2-DCE was not present in any of the samples. Low concentrations of VC were observed from the samples analyzed at ORNL, whereas this compound was not detected in the PORTS analyses. At ORNL, ethane was quantified in all the samples analyzed. During sampling days July 18, 1996 and August 7, 1996, a duplicate set of samples were analyzed on a separate instrument that was capable of separating and quantifying ethane, ethene, and methane.

Monitoring columns were originally installed on the system treatment trains to obtain detailed data from a larger number of sampling points (i.e., residence times). Flow rates in the monitoring columns and corresponding canister trains were intended to be adjusted so that residence times were approximately the same. This proved to be difficult in the X625 facility, where flow is maintained by gravity alone and the inlet pressure is low and varies somewhat with time. In addition, accurate flow measurement through the monitoring column was problematic. Electronic flow meters were initially installed, but these malfunctioned within a few weeks of system start-up because of clogging by fines. Rotameters were then placed in line with the monitoring columns, but these were found to be unreliable after several months of use. In the latter part of July, manual measurement of flow through the treatment columns was performed daily by discharging the monitoring column effluent lines at the atmosphere pressure. In the following presentation of analytical results, only monitoring column data from the early (on and before April 20, 1996) and later (on and after July 31,1996 ) sampling events are included. The measured flow rates during these dates were sufficiently accurate.

This section consists of three parts: TCE degradation rates and half-lives are presented in Sect. 3.1.1; the observed by-products of TCE degradation are discussed in Sect. 3.1.2; and results of laboratory tests on used filings were summarized in Sect. 3.1.3. TCE and byproduct concentrations in the influent and effluent are summarized in the appendix.

\subsubsection{Reaction Kinetics}

At system start-up, TCE was effectively removed in all three treatment trains. During the first week of operation, influent TCE concentrations on the order of $170 \mathrm{ppb}$ decreased to below the detection limit $(2 \mathrm{ppb})$ in all treatment trains. After 51 days of operation, effluent TCE concentrations in the Peerless and palladized iron treatment trains were 3 and $12 \mathrm{ppb}$, respectively. By August 20,1996, after approximately half a 
year (168 days) of operation, all types of filings show different degree of reduction in treatment efficiencies. Noted that over the treatment period described in this report (from March through mid-August 1996), the INFLUENT TCE concentration declined from 170 ppb to approximately $70 \mathrm{ppb}$.

The reaction half-lives over the period of operation were calculated on the basis of a firstorder reaction, which is described as follows:

$$
\mathrm{dC} / \mathrm{dt}=-\mathrm{kC} \text {, }
$$

where $\mathrm{C}$ is the concentration of TCE and $\mathrm{k}$ is the first-order reaction constant. The halflife is defined as the reaction time at which $50 \%$ removal is achieved (i.e., $C / C_{0}=50 \%$ ):

$$
t_{1 / 2}=\ln \left(C / C_{0}\right) / k=-\ln (0.5) / k
$$

Peerless Iron. TCE removal with Peerless iron filings was rapid both in the monitoring column and in the canisters within a week after the system began operation (Table 3 and Fig. 14). Up to $3 / 12 / 96$, approximately 45 pore volume of water was treated. Laboratory experiments indicated that the reaction in the flow through system reaches steady state after 30 pore volumes. In this period, the system had just about to reached a steady state condition, and the fast removal of TCE was artificial (half life was $19 \mathrm{~min}$ ). By March 28,1996 , approximately 150 pore volumes of groundwater had flowed through the treatment train, and steady-state was assumed to have been established. The half-life was $43.4 \mathrm{~min}$, based on TCE data from March 28, 1996 through June 6, 1996. During this time period, TCE removal vs residence time was consistent (Fig. 14); this consistence indicates that the performance of the iron filings was holding steady. The production of ethane, the complete dechlorination by-product from TCE, was also consistent within this time frame (Fig. 15). From June 19, 1996 through August 20, 1996, TCE degradation appeared to show two regions: a fast initial rate followed by a slower removal (Fig. 16). At the same time, ethane levels were lower and more scattered (Fig. 17).

A more apparent deterioration in treatment performance was noted in the Peerless monitoring column, where TCE half-life almost doubled from $36.6 \mathrm{~min}$ on $3 / 28$ to $69 \mathrm{~min}$ from July 31 through August 20 (Fig. 18). This change of degradation characteristics with time can result from (1) reduction in iron surface reactivity and (2) alteration of flow paths through the iron filings as a result of precipitation/clogging. It appears that the Peerless iron filings in the canisters and monitoring columns are undergoing different change with time. These differences may be due to the unequal number of pore volumes that have passed through the column and the canisters, resulting from the difficulty of maintaining the same residence times in both systems under the low inlet pressures. 
Table 3. Summary of trichloroethylene half-lives in the Peerless treatment train.

\begin{tabular}{lccc}
\hline \hline Container type & $\begin{array}{c}\text { Pore volumes } \\
\text { treated }\end{array}$ & $\begin{array}{c}\text { Dates } \\
\text { (Pore volumes treated) }\end{array}$ & $\begin{array}{l}\text { Estimated } \\
\text { trichloroethylene } \\
\text { half-life (min) }\end{array}$ \\
\hline \hline Canisters & $0-45$ & $03 / 06 / 96-03 / 12 / 96$ & 19 \\
& $144-562$ & $03 / 28 / 86-06 / 06 / 96$ & 43.4 \\
& $633-895$ & $06 / 19 / 96-08 / 20 / 96$ & $\sim 20$ \\
& & & $\begin{array}{l}\text { degradation not } \\
\text { first-order }\end{array}$ \\
\hline Monitoring column & $0-144$ & $03 / 28 / 96$ & 36.6 \\
& $856-895$ & $07 / 31 / 96-08 / 20 / 96$ & 69.0 \\
\hline
\end{tabular}

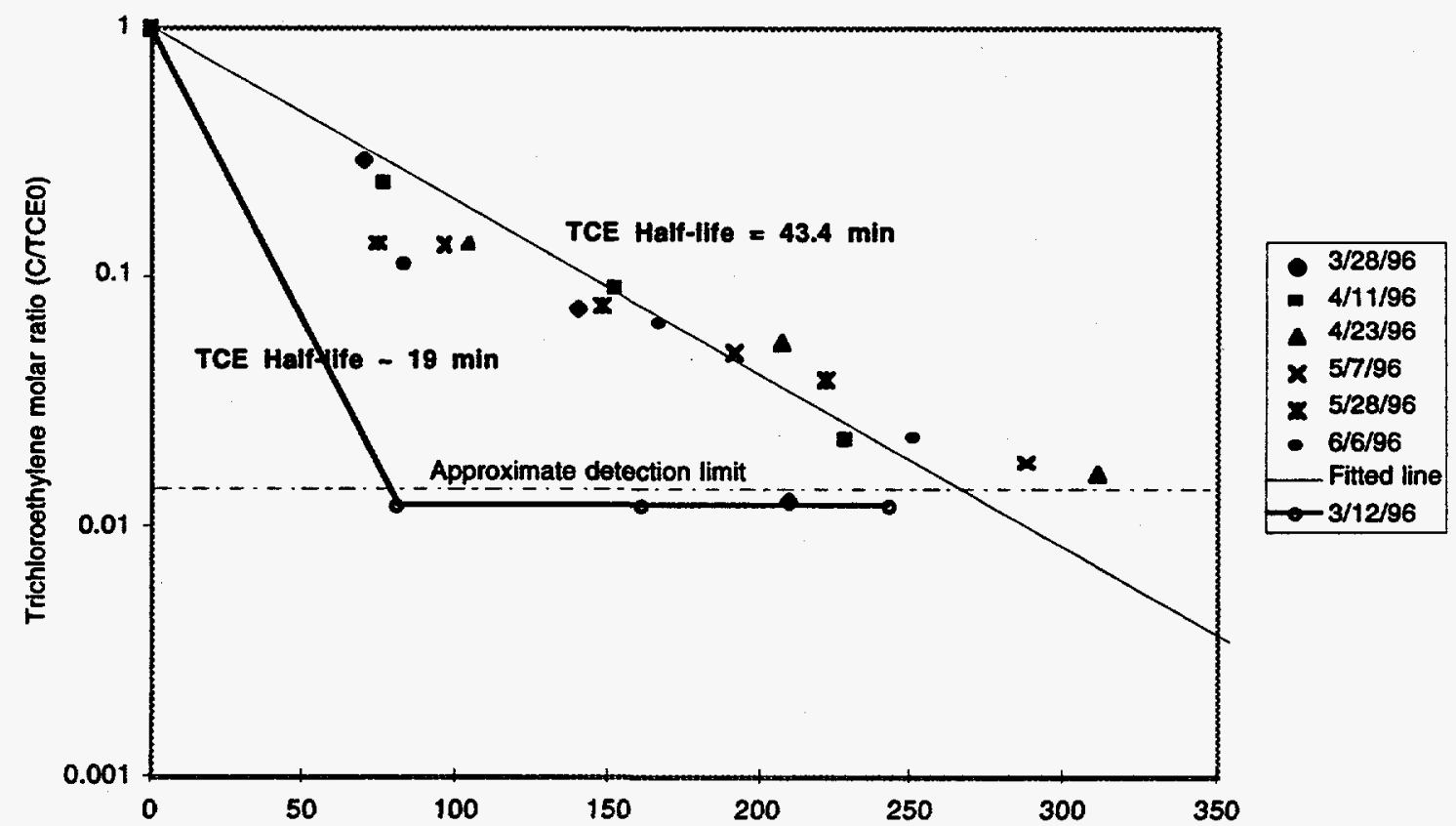

Fig. 14. Trichloroethylene degradation in Peerless canisters, measured March 12, 1996 through June 6, 1996. 


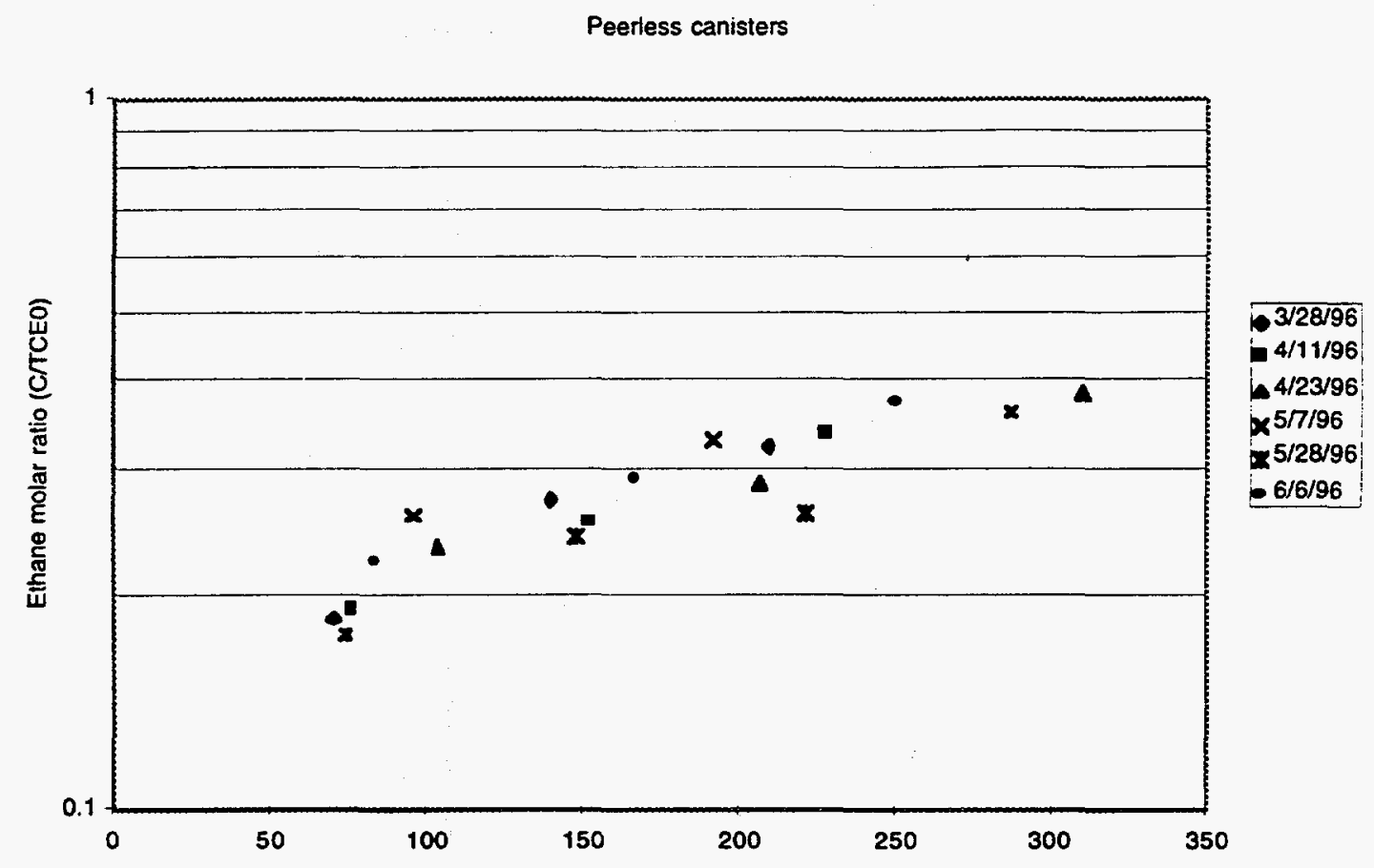

Fig. 15. Ethane production in Peerless canisters, measured March 28, 1996 through June $6,1996$.

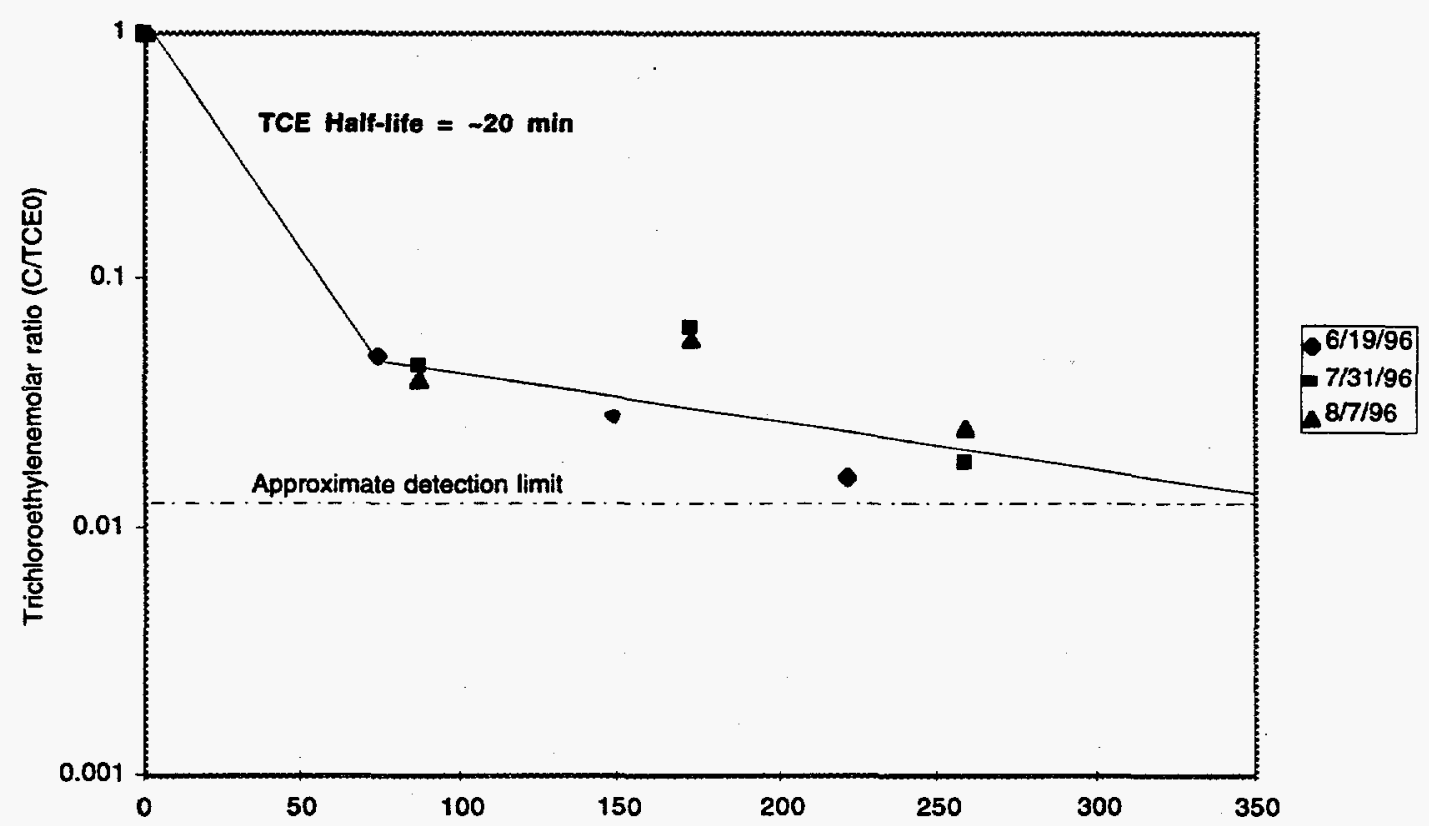

Fig. 16. Trichloroethylene degradation in Peerless canisters, measured June 19, 1996 through August 7, 1996. 
Peeriess Canisters

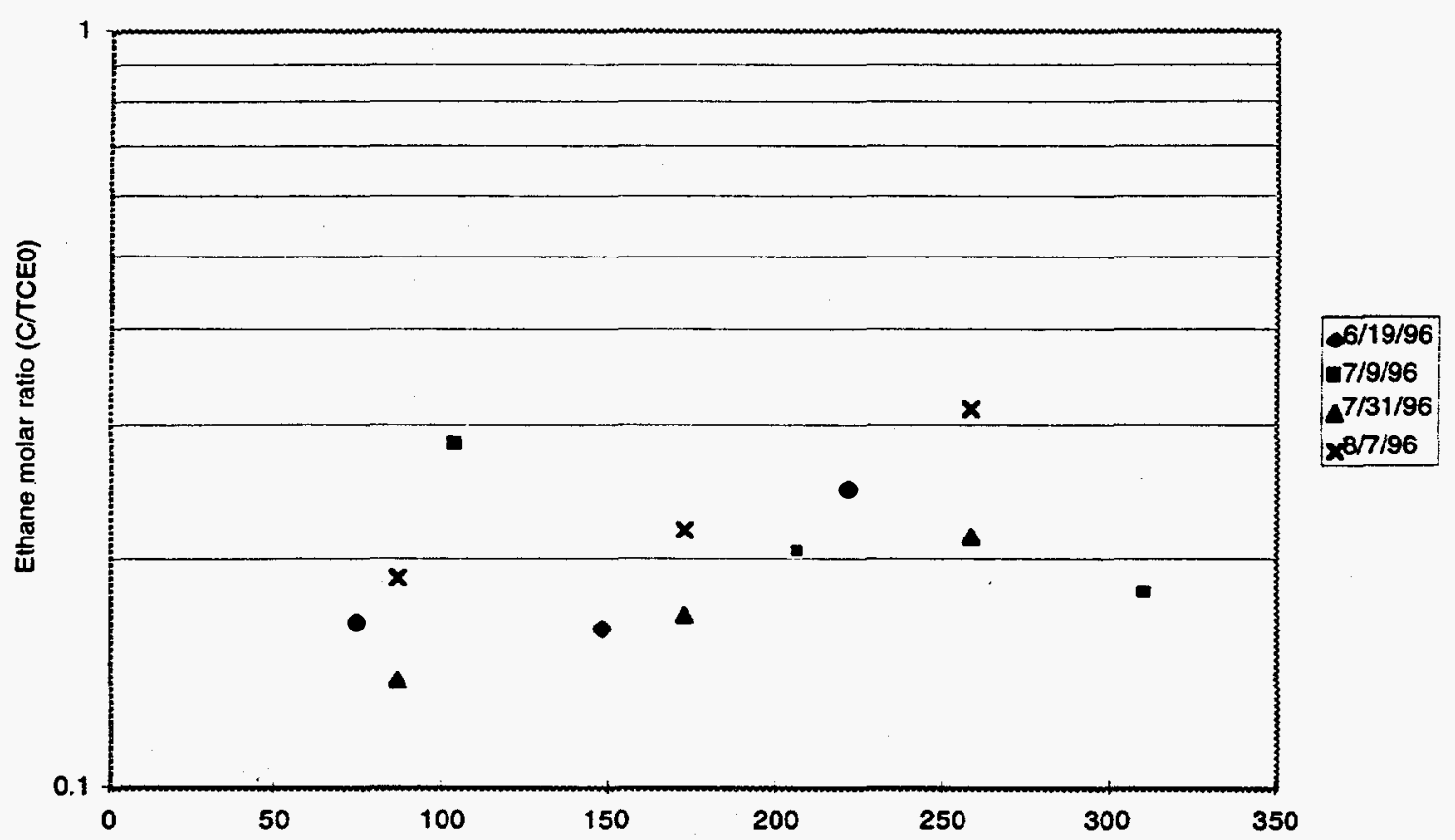

Fig. 17. Ethane production in Peerless treatment trains, measured from June 19, 1996 through August 7, 1996.

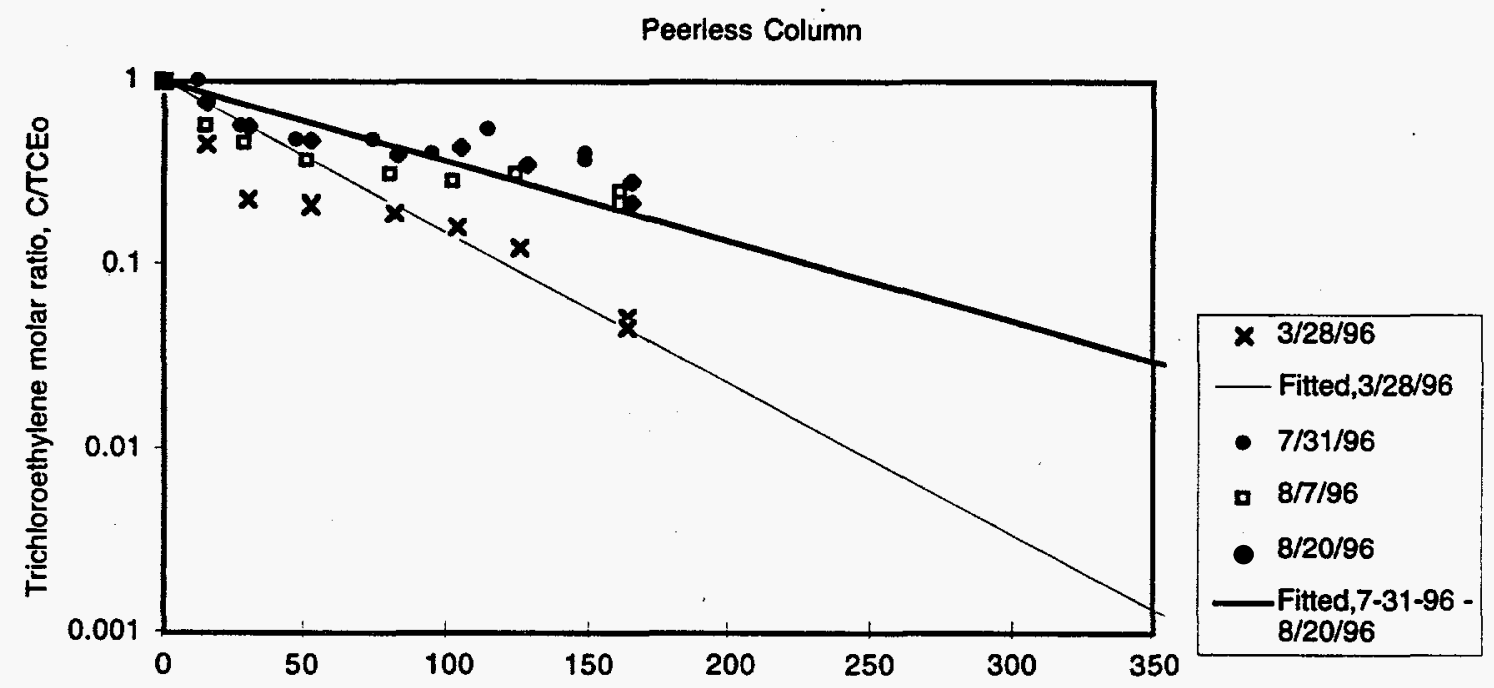

Fig. 18. Trichloroethylene degradation in Peerless monitoring column, measured on March 28, 1996 and from July 31, 1996 through August 20, 1996. 
Master Builders Iron. TCE degradation rates were more consistent between the canisters and the monitoring column of the Master Builders treatment train (see Fig. 19, 20, 21, and Table 4). Shortly after system start-up, TCE was rapidly removed with half-lives on the order of $10 \mathrm{~min}$. However, as for the Peerless media, this initial rapid removal is artificial because the system had not reached steady state. TCE half-life remained at $-40 \mathrm{~min}$ in both the canisters and the monitoring column after the system reached steady state condition (Fig. 19). The TCE degradation rate remained approximately the same even when the first canister was taken off-line (Fig. 20 and Table 4). Ethane production appeared to have increased from less than $30 \%$ to $40 \%$ upon removal of the first canister, (Fig. 22 and 23). These results indicate that over the 5 months of operation, the reactivity of iron filings from Master Builder has not deteriorated. With this type of filing, sorption of the VOCs seemed to be much faster than the reductive dechlorination. The major problem of clogging is primarily due to the small size of the filings.

Table 4. Summary of trichloroethylene half-lives in the Master Builders treatment train

\begin{tabular}{lccc}
\hline \hline Container Type & $\begin{array}{c}\text { Pore volumes } \\
\text { treated }\end{array}$ & Dates & $\begin{array}{c}\text { Estimated } \\
\text { trichloroethylene } \\
\text { half-life (min) }\end{array}$ \\
\hline \hline Canisters & & & \\
3 canisters & $0-45$ & $03 / 12 / 96$ & $\sim 10$ \\
3 canisters & $326-379$ & $04 / 11 / 96-05 / 29 / 96$ & 43.5 \\
& & & \\
2 canisters & $579-823$ & $06 / 19 / 96-08 / 7 / 96$ & 42.7 \\
\hline Monitoring column & $0-25$ & $03 / 12 / 96$ & 13.8 \\
& $856-895$ & $07 / 31 / 96-08 / 07 / 96$ & 41.4 \\
\hline
\end{tabular}




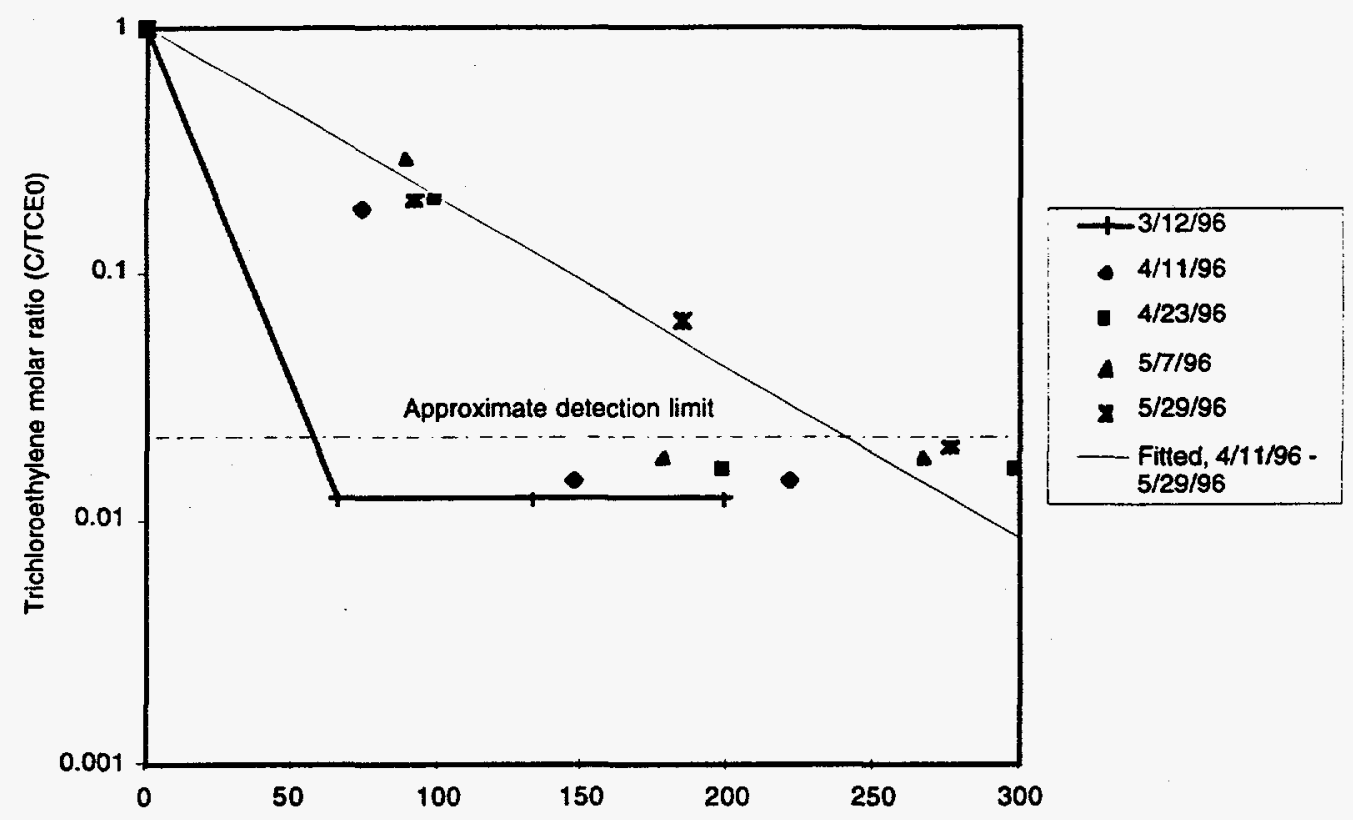

Fig. 19. Trichloroethylene degradation in the Master Builders treatment trains (with three canisters), measured on March 12, 1996 through May 28, 1996.

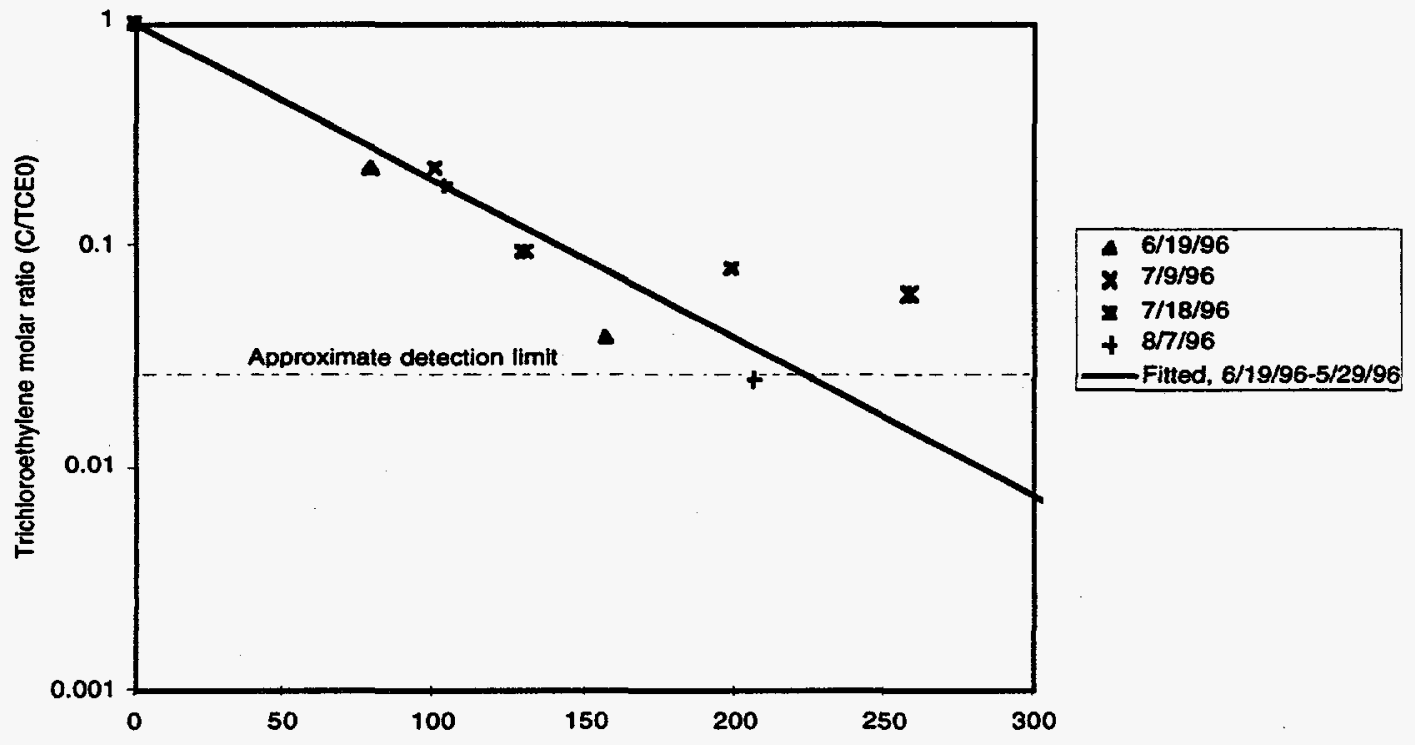

Fig. 20. Trichloroethylene degradation in the Master Builders treatment trains (with two canisters), measured from June 19, 1996 through August 7, 1996. 


\section{Master Builders Column}

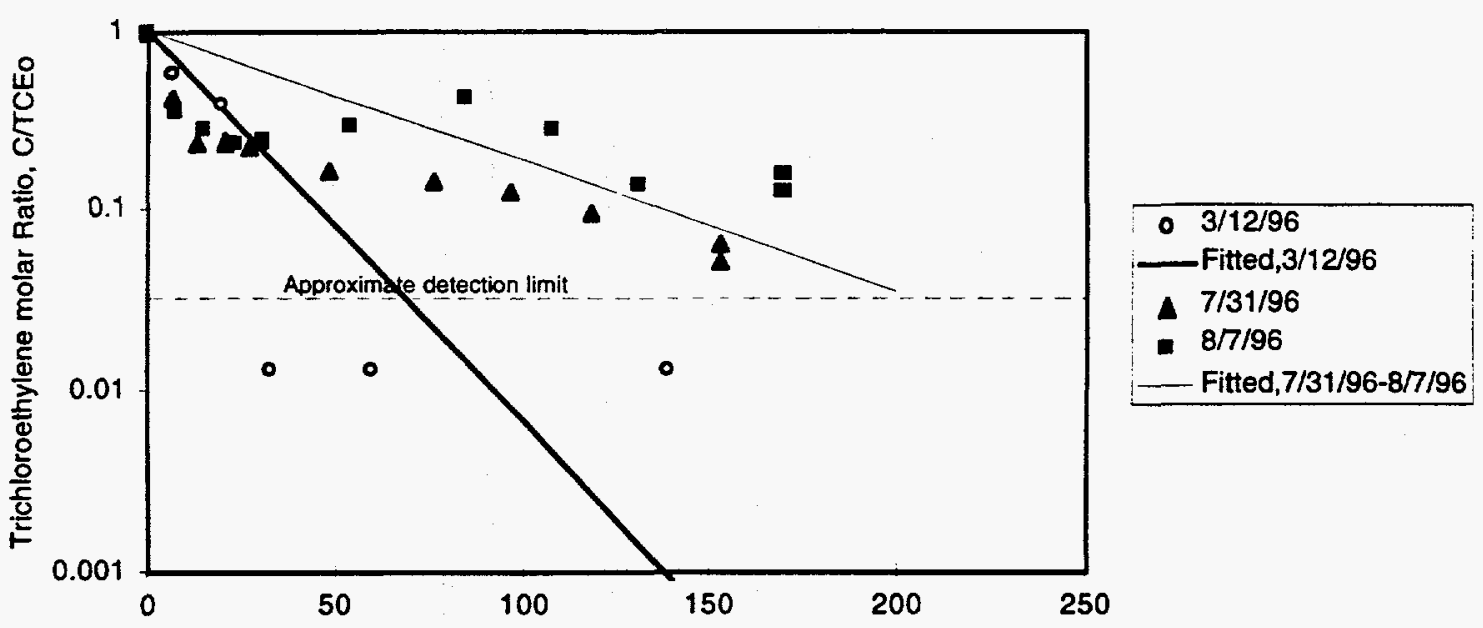

Fig. 21. Trichloroethylene degradation in Master Builders monitoring column, measured on March 12, 1996 and from July 31, 1996 through August 7, 1996.

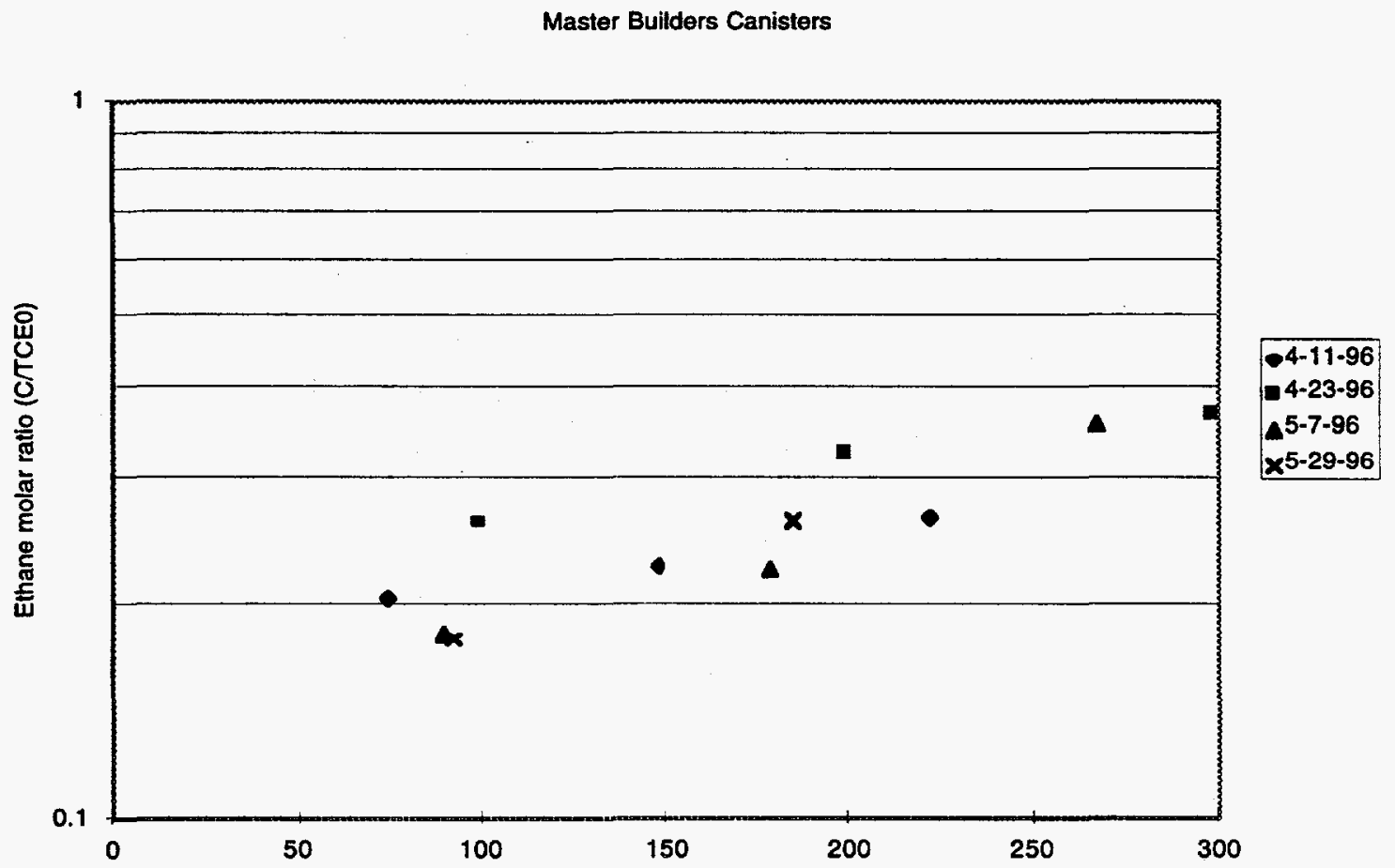

Fig. 22. Ethane production in Master Builders treatment train (three canisters), measured from April 11, 1996 through May 29, 1996. 
Master Builders Canisters

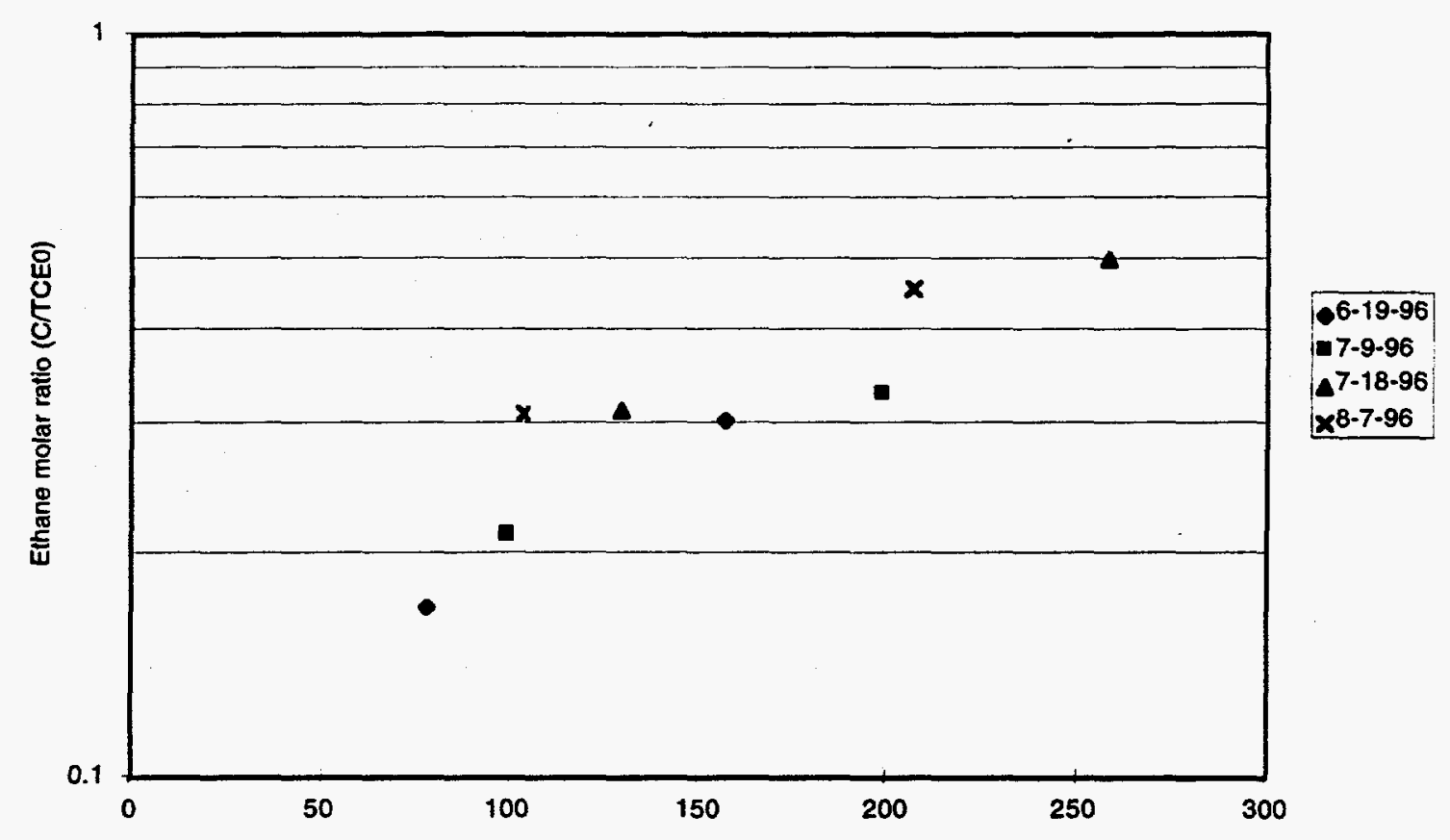

Fig. 23. Ethane production in Master Builders treatment train (two canisters), measured from June 19, 1996 through August 7, 1996. 
Palladized Iron. The palladized iron treatment train initially removed TCE to non-detect levels during and shortly after system start-up, accompanied by the near complete recovery of TCE as ethane (see Fig. 24). Because of the fast flow rate relative to the volume of iron in the canister, a steady state condition was established after one day of set-up. Twenty-three days later, after having treated 12,960 gallons or 1,826 pore volumes of groundwater, TCE broke through the palladized iron canister and was measured at molar ratios from 0.25 to 0.5 relative to the influent concentration. The reduction in reactivity of the iron filings was also reflected in the lower levels of ethane measured in the canister effluent (see Fig. 24). The monitoring column also exhibited similar diminishing TCE degradation rates and ethane production (see Fig. 25). TCE halflives estimated from the monitoring column measurements are shown in Table 5; degradation rates could not be calculated from the canister measurements because there were only two data points (influent and effluent levels through a single canister).

Table 5. Summary of trichloroethylene half-lives in the palladized iron treatment train.

\begin{tabular}{cccc}
\hline \hline Container Type & Pore volumes treated & Dates & $\begin{array}{c}\text { Estimated } \\
\text { trichloroethylene } \\
\text { half-life (min) }\end{array}$ \\
\hline \hline 66 & $03 / 06 / 96$ & 0.6
\end{tabular}

Monitoring column

The observations noted for all treatment trains regarding changes in TCE degradation show the importance of long-term testing using field-contaminated water to evaluate the performance of reactive barrier materials. The duration of previous laboratory experiments were normally short, and only up to 1000 pore volumes were used. However, these laboratory studies have already indicated iron filing performance can deteriorate and reaction rate constants were reduced under prolonged reaction times. For example, laboratory studies showed that after 100 pore volumes flowed through Master Builder media, the half-life was $1.9 \mathrm{~min}$. The half-life increased to $23 \mathrm{~min}$ after treatment of 300 pore volumes. For palladized iron filings, the change in half-lives for TCE degradation was expected on the basis of laboratory studies in which similar changes were observed after several hundred pore volumes of water were treated. Laboratory studies showed that after treatment of several hundreds of pore volumes of water, a fractional increase in half-life was observed (from 0.34 to $0.5 \mathrm{~min}$ ). Until the field test, the more extensive aging of palladized iron after treatment of a thousand pore volumes of TCEcontaminated groundwater was unknown; the half-life increased by an order of magnitude, from $0.6 \mathrm{~min}$ to $19 \mathrm{~min}$ (see Table 5). The rapid deterioration of palladized iron may be due to sulfide poisoning of the palladium catalyst. At PORTS, microbial-mediated sulfate reduction to sulfide may have increased the chance of forming PdS in the field. These 
microbes were probably not present in the previous laboratory experiments. Mechanisms responsible for the deterioration of palladized iron must be addressed in future studies.

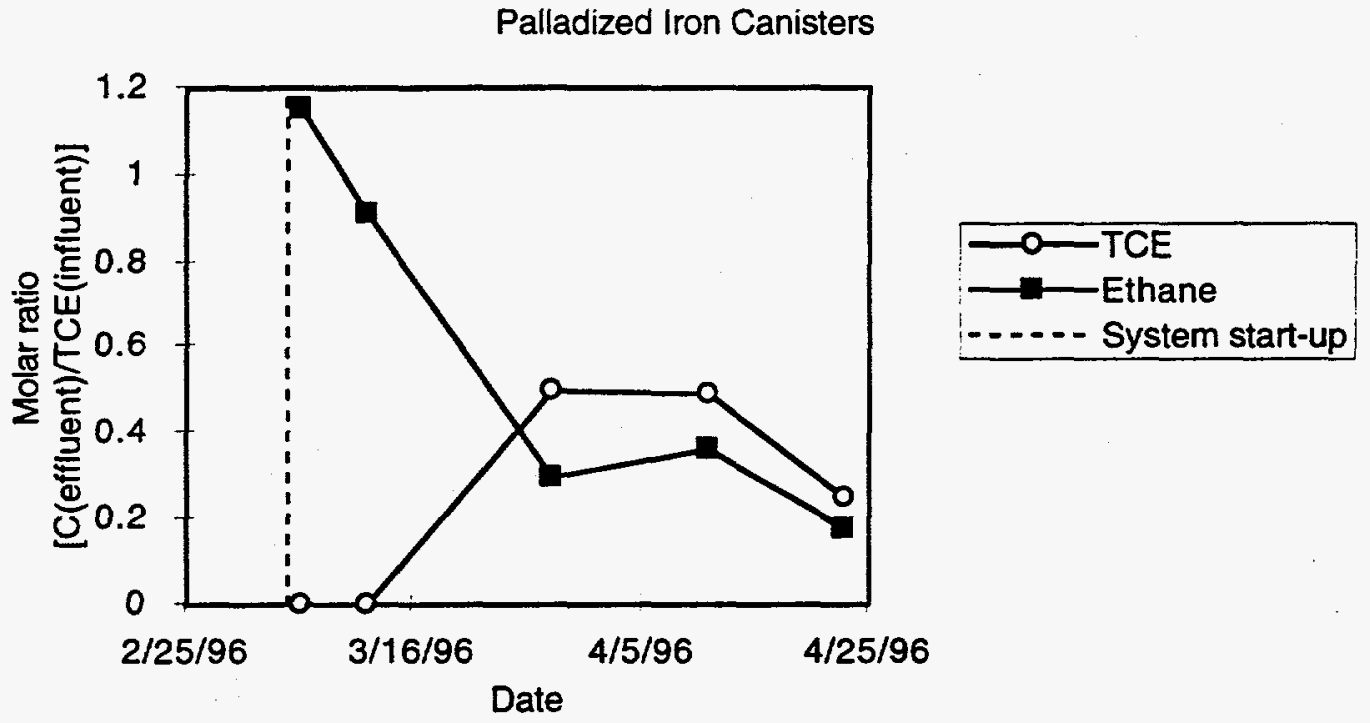

Fig. 24. Molar ratio of trichloroethylene effluent and ethane effluent to trichloroethylene influent concentrations in the palladized iron treatment train. Residence times: $\sim 20$ min for all sampling dates. 


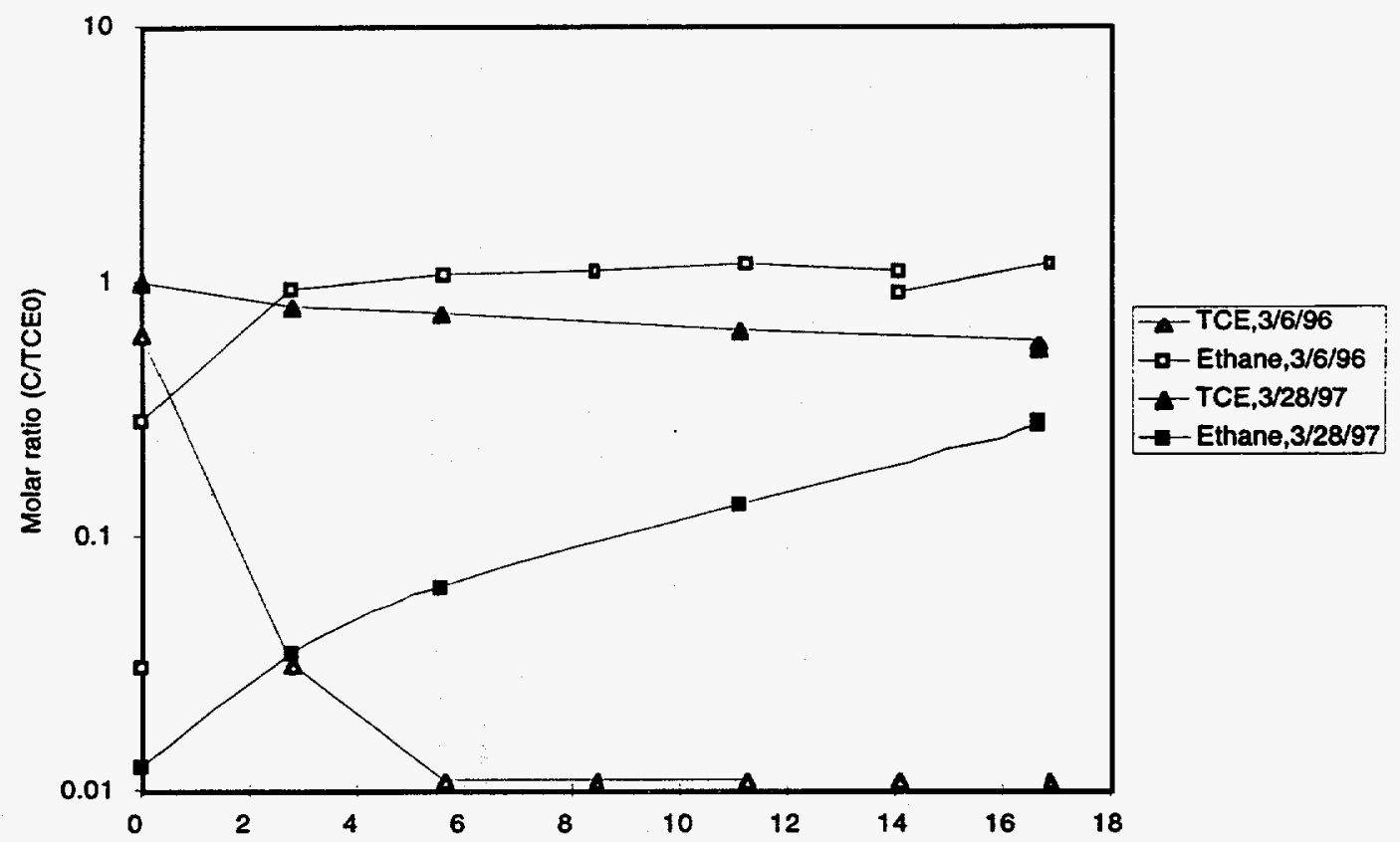

Fig. 25. Trichloroethylene degradation and ethane production from the palladized iron packed monitoring column, measured on March 6, 1996 and March 28, 1996.

\subsubsection{By-product Distribution}

In all treatment trains, TCE concentrations decreased along the flowpath through the treatment media. Cis-1,2-DCE, VC, ethane, and ethylene were produced as volatile organic byproducts. Figures 26 through 28 shows the distribution of TCE and byproducts vs residence time for different media tested during two sampling events (ethylene was only quantified in the samples collected on August 7, 1996). The top plots in each of the figures show the byproduct distribution during the initial stage of treatment (March 6, 1996), whereas the bottom plots depict the same information after 155 days for the Master Builders and Peerless media (August 7, 1996) and after 23 days for the palladized iron media (March 28, 1996). The linear plot of logarithmic TCE concentration versus retention time indicates that the reaction is approximately first order for the Peerless and Master Builders media during the earlier sampling event (Fig. 26a and 27a). The linear relationship is somewhat poor for the Peerless and Master Builder media during the later sampling events (Figs. 26b and 27b). On the contrary, degradation in the palladized iron media starts out non-linear on a semi-logarithmic plot of TCE vs residence time (Fig. 28a) then becomes more linear as time progressed (Fig. 28b). 
The length of system operation affects the performance of iron filings in several ways: (1) TCE degradation slows down, (2) less ethane was produced, and (3) both cis-DCE and VC become more persistent. By August 7, 1996, the breakthrough of all VOCs was observed from the Master Builders and Peerless treatment trains. At this point, 989 and 895 pore volumes of groundwater had been treated by the Master Builders and Peerless trains, respectively. Figure 28 shows that the breakthrough of VOCs in the palladized iron media occurred by March 28, after more than 1,826 pore volumes treated by the material. Note that the residence time was much shorter for this media compared with the Master Builders and Peerless iron media.

Mass balance. The mass balance was near $100 \%$ in the Peerless monitoring column on August 7, 1996 [Fig. 26(b)]. Shortly after system start-up, the mass balance in the Master Builders monitoring column was poor [Fig. 27(a)]. At this stage, TCE removal was a combination of dechlorination and sorption. On August 7, 1996 (Fig. 27(b)), the mass balance was improved, perhaps since the sorption had reached a steady state condition. For the palladized iron filings, complete recovery of TCE as ethane was observed on 3/6/96 (see Fig. 28(a). On 3/28/96, the reaction had slowed down and breakthrough of TCE was observed. 


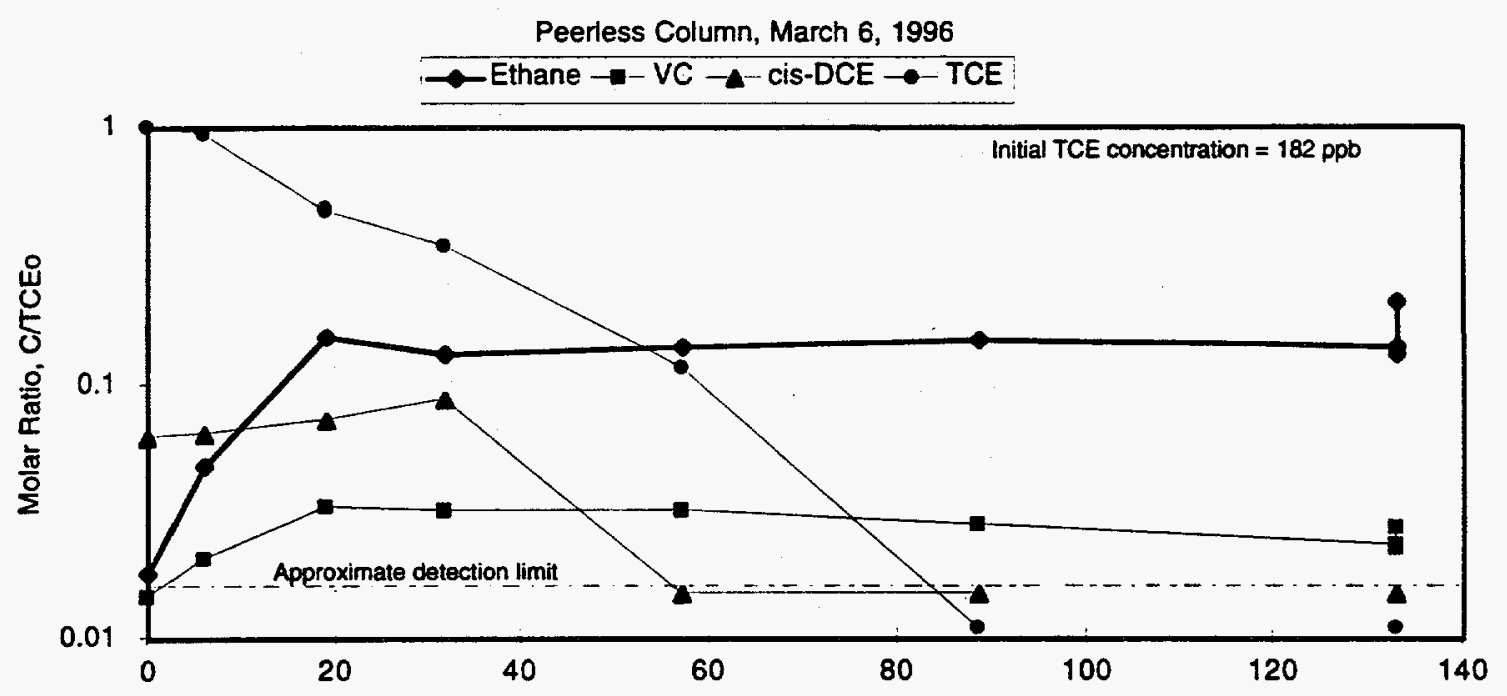

(a)

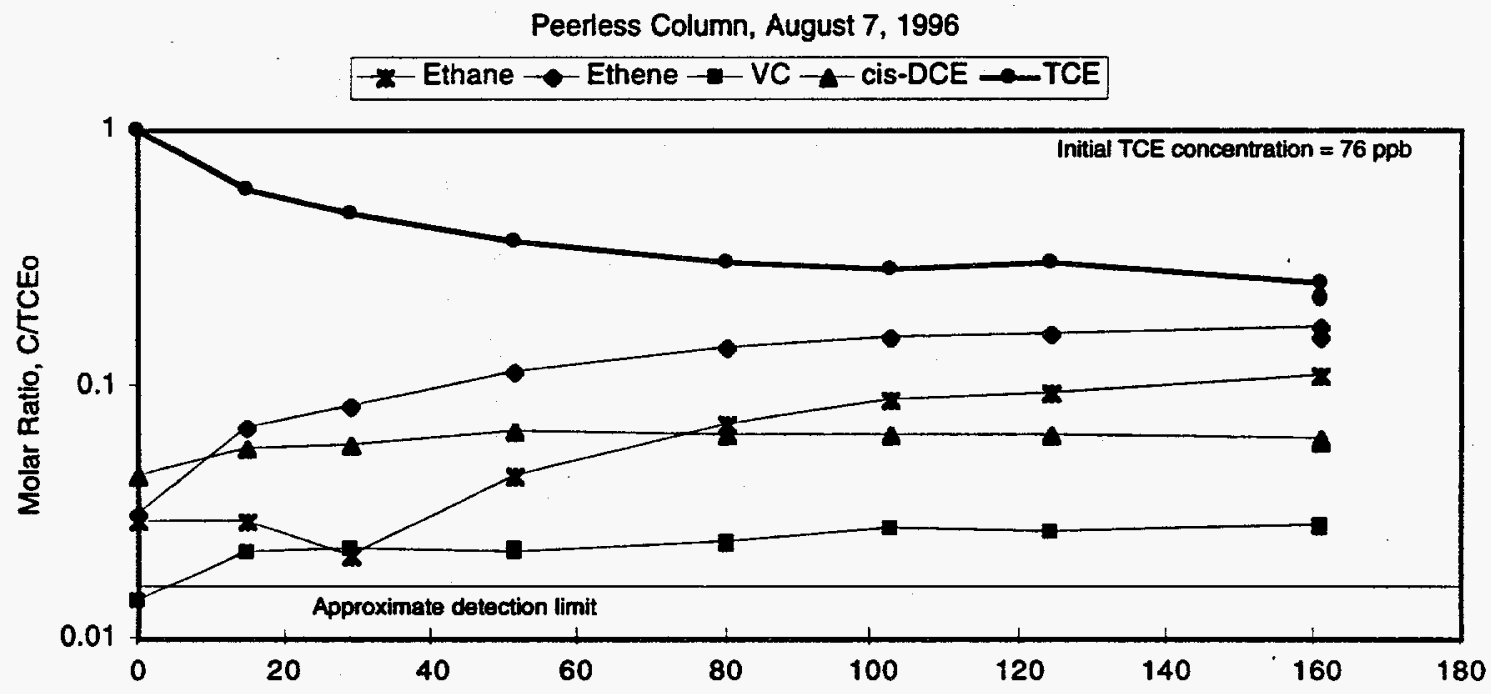

(b)

Fig. 26. Trichloroethylene and degradation by-products observed on (a) March 6, 1996, and (b) August 7, 1996 in the Peerless media packed column. 


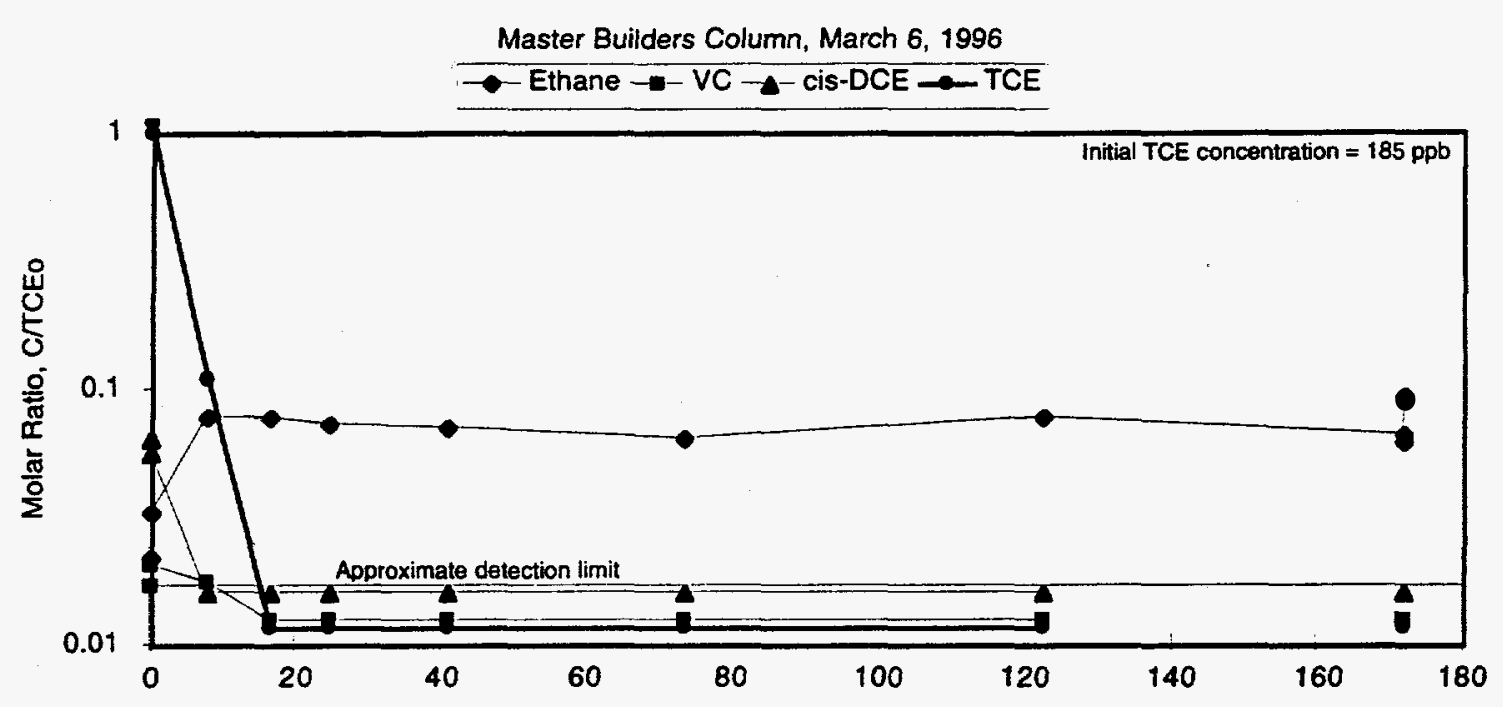

(a)

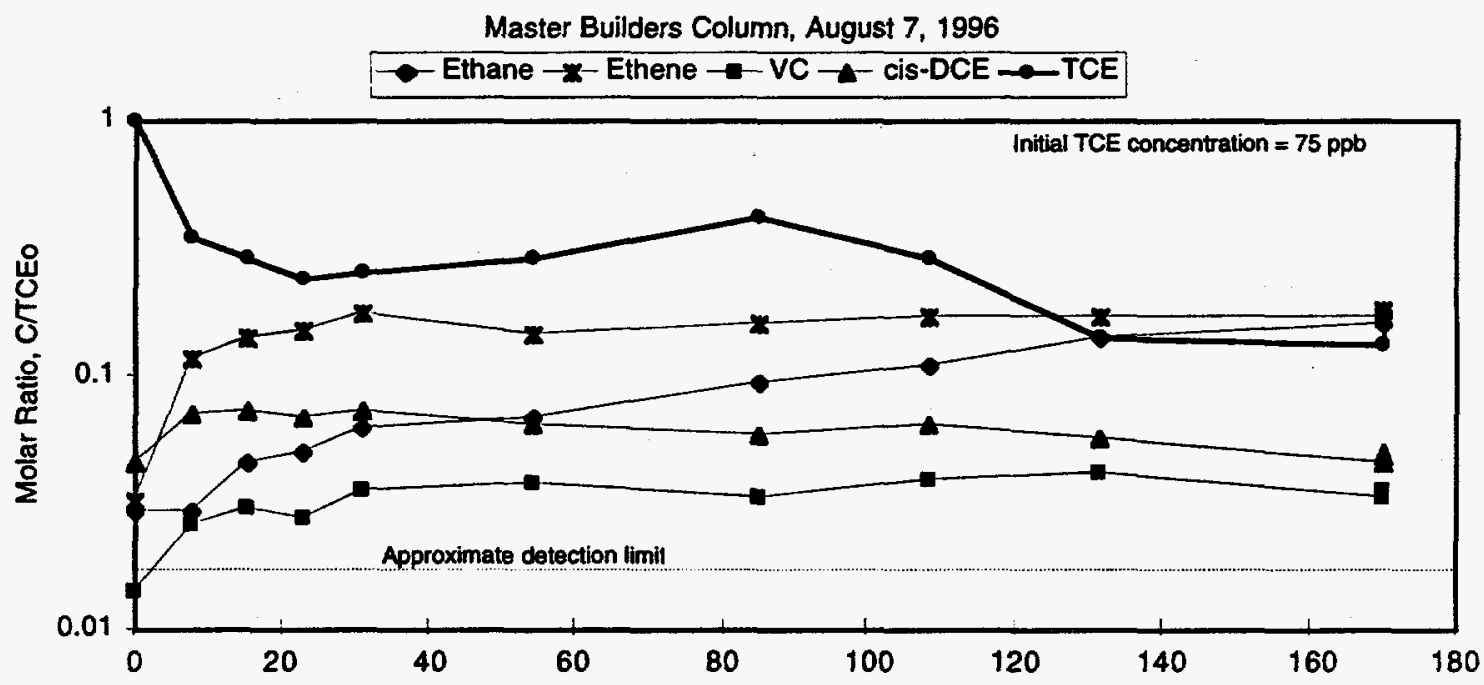

(b)

Fig. 27. Trichloroethylene and degradation by-products observed on (a) March 6, 1996, and (b) August 7, 1996 in the packed column of Master Builder's filings. 


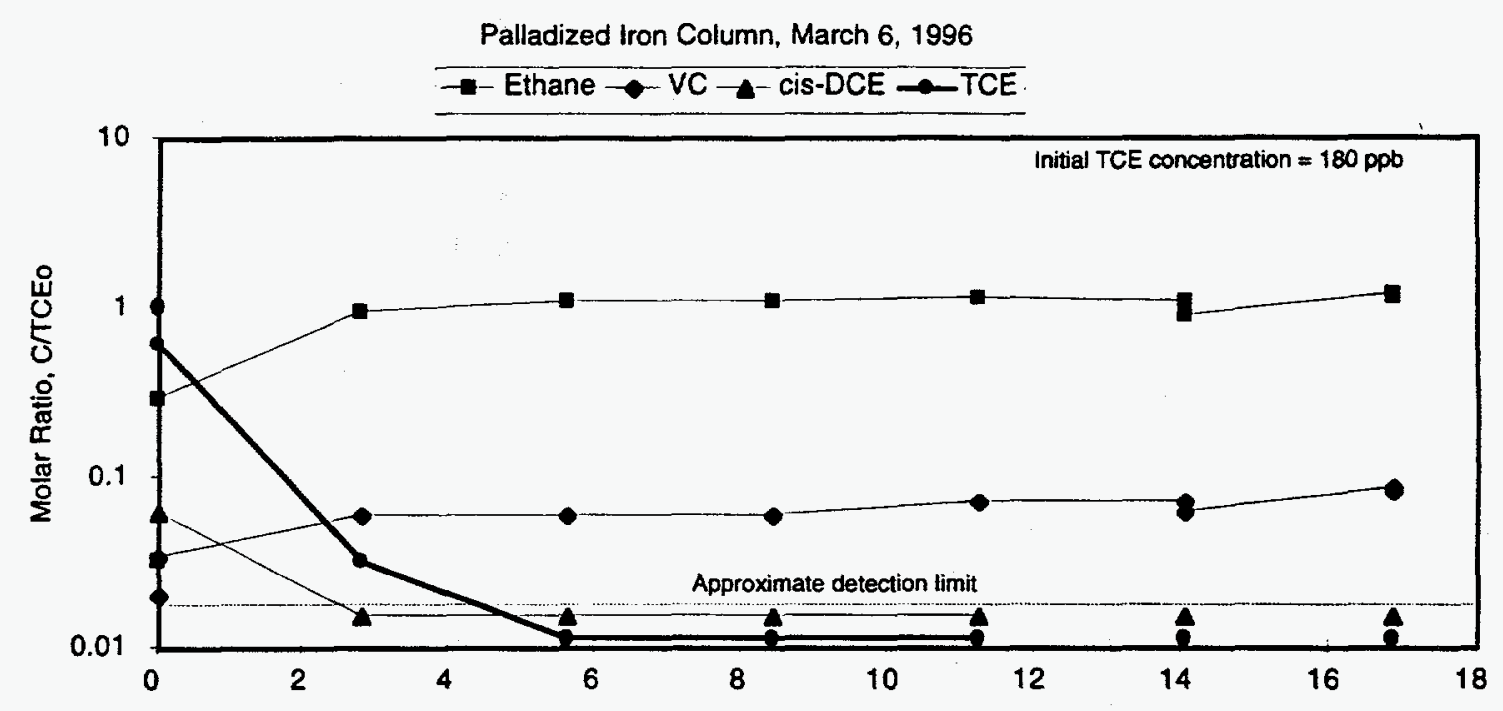

(a)

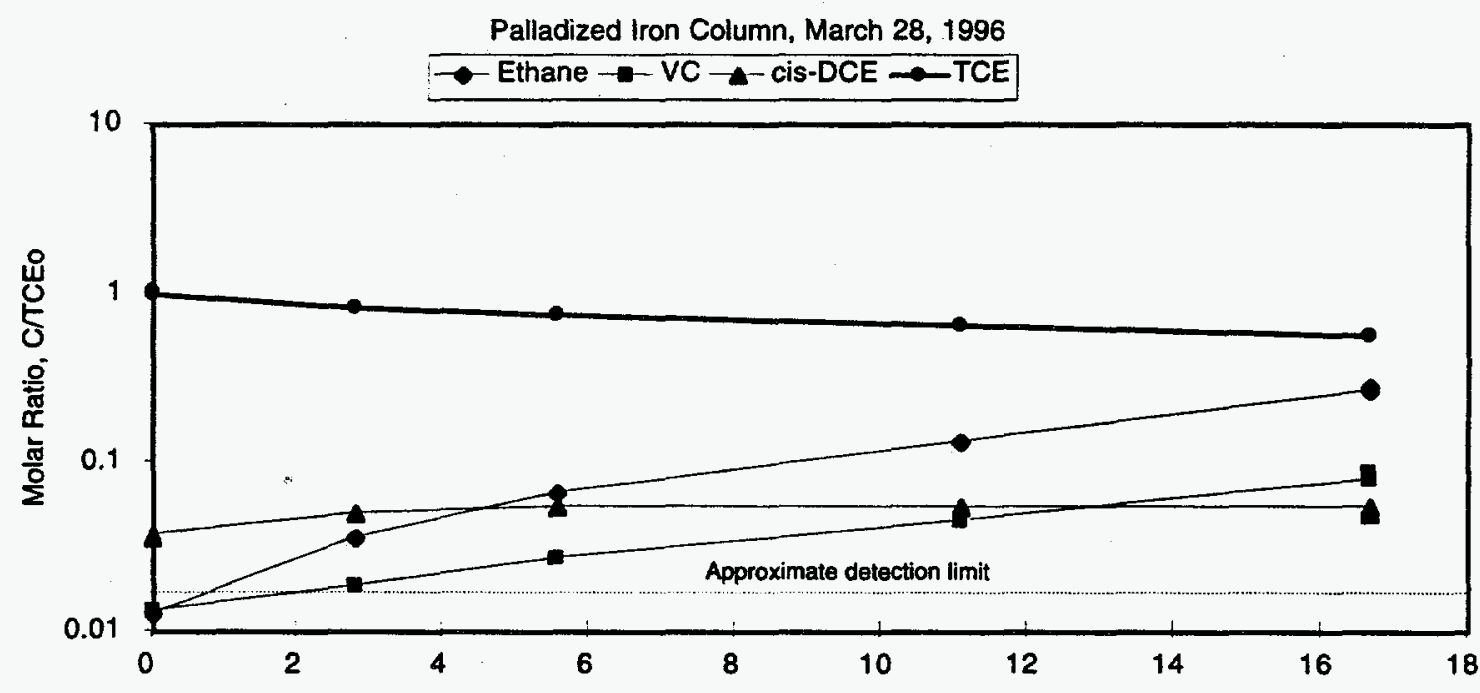

(b)

Fig. 28. Trichloroethylene and degradation by-products observed on (a) March 6, 1996, and (b) March 28, 1996 in the column of palladized iron. 


\subsubsection{Laboratory Evaluation of Used Iron Filings}

Batch studies were conducted with iron filing samples that had been used in the field for the treatment of TCE contaminated groundwater. The objective for doing these tests was to verify the field degradation rates with laboratory experiments, and to compare the rates of the used filings with the values of unused material (Table 6).

Table 6. Trichloroethylene half-lives in flow-through iron filing columns

\begin{tabular}{lccc}
\hline \hline Iron type & $\begin{array}{c}\text { Laboratory- } \\
\text { measured half-life } \\
\text { for unused filings } \\
(\mathrm{min})\end{array}$ & $\begin{array}{c}\text { Half-life measured at } \\
\text { X-625 } \\
(\mathrm{min})^{c}\end{array}$ & $\begin{array}{c}\text { Laboratory } \\
\text { measured half-life } \\
\text { for used filings } \\
(\mathrm{min})\end{array}$ \\
\hline \hline Peerless & 45 & $43^{a}$ & $51^{b}$ \\
Master Builders & 23 & $42-43$ & $29^{b}$ \\
Palladized iron & $0.6^{b}$ & 19 & $3.4^{b}$ \\
\hline
\end{tabular}

${ }^{a}$ This was estimated from data collected between March 28, 1996 and June 6, 1996 (Fig. 14). Degradation from June 19, 1996 through August 20, 1996 was not first order and is NOT used here (Fig. 16).

${ }^{b}$ Estimated from batch studies by dividing batch degradation rate by 25 (i.e., the ratio between solid:solution ratios in column and batch experiments).

${ }^{c}$ Half-lives were estimated with data from $3 / 28 / 96$ to $8 / 8 / 96$, unless noted.

The degradation rate for the used Peerless iron filings was slower than the observed rate with unused filings (Table 6). Both half-lives are comparable to the field-measured TCE half-life from March 28, 1996 through June 6, 1996 (i.e., the reactivity of the iron filings did not change significantly). The change in degradation behavior from $6 / 19 / 96$ through $8 / 20 / 96$ observed in the field is likely due to changes in the hydraulic characteristics of the media in the canisters, with a possible enhancement of microbially mediated contaminant degradation.

The field-measured degradation rate of the Master Builder filings is almost twice as slow as measured with the used and unused material in the laboratory. There was a slight increase in half-life in the used filings; however this cannot account for the significantly higher half-life in the canisters. Since the grain size of the Master Builder filings was relatively small, clogging generated hydraulic heterogeneity. The slower degradation of the Master Builder media is likely due to preferential flow paths that reduce the effective groundwater residence time in the field.

The half-life of TCE with the used palladized iron filings increased by almost six times in relation to the unused material, indicating a significant decrease in reactivity of palladized iron with extended use. As mentioned earlier, this reactivity reduction may be due to poisoning of the palladium catalyst by sulfides, produced by the microbial reduction of 
sulfates present at high levels in the site groundwater. The field half-life is also significantly longer than the half-life of the used palladized iron filings. As for the Master Builder media, the latter may be due to preferential flow paths formed when the fine iron particles become cemented with prolonged treatment of the groundwater.

Efforts have been made to find a regeneration procedure for the palladized iron filings. Hydrochloric and citric acid (both at $1 M$ concentrations) were used to rinse samples taken from the monitoring column of the palladized iron. Subsequent measurements of TCE degradation with the washed filings showed that the material had not been brought back to its virgin state (i.e., TCE half-lives were still greater than $3 \mathrm{~min}$ ). Future work should include a continued search for a regeneration procedure, guided by and investigation of the mechanisms responsible for the reduced reactivity of palladized iron filings. Complexing agents are preferred because acid will accelerate the corrosion of the base metal, iron.

\subsection{Water Chemistry}

Periodic sampling was conducted to measure the following physical/chemical parameters for both monitoring columns and treatment canisters: $\mathrm{pH}, \mathrm{DO}, \mathrm{Fe}(\mathrm{II})$, alkalinity and turbidity. Sulfate and sulfide concentrations were determined in selected sampling ports. In general, the trend in the chemical parameters agree with laboratory observations. The turbidity has been low ( 1 NTU) after the shake-down period.

\subsubsection{Influent Water Chemistry}

The basic chemical parameters of the influent water did not change significantly since the system start-up in March 1996 (see Table 7). Variations in dissolved oxygen measurements were most likely due to contamination of atmospheric oxygen at low DO levels. Alkalinity was relatively constant through June 1996 at $80-85 \mathrm{mg} / \mathrm{L}$ (as $\mathrm{CaCO}_{3}$ ); but later decreased to $50 \mathrm{mg} / \mathrm{L}$. The extremely high groundwater turbidity measured on July 11, 1996 may have been an erroneous measurement. The most recent measurement August 22, 1996 is more consistent with previous data.

\subsection{2 pH Change in the Treatment Trains}

The $\mathrm{pH}$ was observed to increase as the groundwater flowed into the treatment media (Table 8). The $\mathrm{pH}$ change was consistent with laboratory work conducted with the site water (i.e., the effluent $\mathrm{pH}$ has been buffered at about 7.5). Only during the start-up period was a higher $\mathrm{pH}$ value of 8.3 observed in the Master Builders media. 
Table 7. Influent water chemical parameters

\begin{tabular}{cccccc}
\hline \hline $\begin{array}{c}\text { Date of } \\
\text { Sampling }\end{array}$ & $\mathrm{pH}$ & $\begin{array}{c}\text { Dissolved } \\
\text { oxygen } \\
(\mathrm{ppb})\end{array}$ & $\begin{array}{c}\text { Alkalinity } \\
(\mathrm{mg} / \mathrm{L} \text { as } \\
\mathrm{CaCO})\end{array}$ & $\begin{array}{c}\text { Ferrous iron } \\
(\mathrm{mg} / \mathrm{L})\end{array}$ & $\begin{array}{c}\text { Turbidity } \\
(\mathrm{NTU})\end{array}$ \\
\hline \hline $03 / 06 / 96$ & 5.9 & 82 & 83 & & 1 \\
$03 / 28 / 96$ & 6.1 & 10 & 85 & 5.75 & 1 \\
$04 / 12 / 96$ & 6.2 & 87 & 83 & 5 & 1.2 \\
$04 / 25 / 96$ & 6.2 & 16 & 83 & 5.25 & 1.1 \\
$05 / 09 / 96$ & 5.9 & 27 & 66 & 4.5 & 1.2 \\
$05 / 30 / 96$ & 6.2 & 88 & 80 & 4.5 & 0.1 \\
$06 / 02 / 96$ & 6.2 & 102 & 83 & 4.75 & 0.7 \\
$07 / 11 / 96$ & 5.6 & 24 & 56 & 3.25 & 7.13 \\
$08 / 22 / 96$ & 5.5 & 20 & 50 & 2.5 & 1.1 \\
\hline
\end{tabular}

Table 8. Effluent $\mathrm{pH}$ measured in treatment trains.

\begin{tabular}{cccc}
\hline \hline Date of Sampling & Peerless & Master Builders & Palladized iron \\
\hline \hline $03 / 28 / 96$ & 7.3 & 8.3 & 7 \\
$04 / 12 / 96$ & 7.1 & 7.2 & 6.5 \\
$04 / 25 / 96$ & 7.1 & 7.3 & 6.8 \\
$05 / 09 / 96$ & 6.9 & 7.6 & 7.1 \\
$05 / 30 / 96$ & 7.2 & 7.3 & off-line \\
$06 / 10 / 96$ & 7.3 & 7.2 & off-line \\
$07 / 11 / 96$ & 6.7 & 6.8 & off-line \\
$08 / 22 / 96$ & 6.9 & off-line & 6.5 \\
\hline
\end{tabular}

Because the same groundwater is flowing through the three treatment media, the buffering capacity of the groundwater should be the same. Thus, the difference in the effluent $\mathrm{pH}$ is most likely influenced by the media. The higher effluent $\mathrm{pH}$ registered for Master Builder media indicates that electrolysis of water by iron filings was more extensive, thus producing larger quantities of hydroxide ions (and hydrogen gas) in comparison with the other media. The smaller particle size and the large volume of the Master Builder iron offered the most overall surface sites, thus responsible for the observation. For the palladized iron, the effluent $\mathrm{pH}$ ranged from 6.5 to 7.1 , slightly lower than that of the other treatment media. The small $\mathrm{pH}$ increase (from the influent at 6.1) suggests (1) less reactive surfaces for producing hydroxide ions and (2) buffering from groundwater byproducts (e.g., sulfide and titratable organic compounds) in the palladized iron media. 


\subsubsection{Dissolved Oxygen}

Dissolved oxygen has been one of the difficult parameters to determine in the field. Particularly for low DO containing water, any atmospheric contamination results in erroneously high readings. Several tests were conducted at the site to determine realistic DO levels at each of the sampling ports. With high flows of water, DO levels were measured from 13 to $25 \mathrm{ppb}$ at the sampling ports between canisters. However, the flow is normally low through the monitoring columns, and error in measurements could occur. Nevertheless, most DO data are less than $100 \mathrm{ppb}$. Occasional readings above $100 \mathrm{ppb}$ are attributed to contamination from atmospheric oxygen. The low DO measurements are consistent with the highly reducing condition created by the zero-valence iron in the treatment process.

\subsubsection{Ferrous Iron, Alkalinity, and Sulfate}

Ferrous iron is produced from the reductive dechlorination and the anaerobic reaction between zero-valence iron and water. In both the monitoring columns and the canisters, $\mathrm{Fe}$ (II) increased then subsequently decreased with increasing residence time (see Figs. 29 through 32). Decreases in Fe(II) are associated with the precipitation of ferrous minerals and adsorption.

The maximum aqueous concentration of $\mathrm{Fe}$ (II) at similar $\mathrm{pH}$ is indicative of the reactivity of a particular type of iron. For example, palladized iron is the most reactive among the three types of iron tested, and it produced the highest Fe(II) concentrations measured (see Fig. 31). The rate and amount of ferrous mineral precipitation in the media can be inferred from the difference of the maximum and the effluent $\mathrm{Fe}$ (II) concentration. For example, the difference between influent and effluent $F e(I I)$ concentrations were highest for palladized iron (see Fig. 33), indicating the least amount of ferrous mineral precipitation due to the short residence time in the palladized iron media. A net increase in ferrous concentration was noted throughout the duration of system operation for the Peerless treatment media (Fig. 33). In contrast, the Fe(II) effluent concentration was lower than the influent concentration in the Master Builder media, indicating that precipitation was most significant in this treatment train. This was consistent with the relatively rapid clogging observed for the Master Builders filings (see Sect. 2.5.2).

The high levels of Fe(II) produced by the iron media implies that zero-valence Fe can be consumed at a relatively high rate even under anoxic conditions such as those that exist at the X-625 GTF. Physical evidence of iron consumption can be seen in Figs. 34 and 35, where unused and used Peerless and Master Builders iron filings are compared. The unused iron filings tend to have shiny surfaces with sharp edges (Figs. 34a and 35a). On the contrary, the surfaces of the used iron filings are pitted and have lost their metallic sheen (see Figs. 34b and 35b). The used Master Builder filings also appear to be smaller in size when compared to the unused material (compare Figs. 35a and b). 
Alkalinity followed the same trend as Fe(II), initially increasing then subsequently decreasing with residence time (see Figs. 29 to 32). The cause of the alkalinity increase in the iron media is unknown. We postulate that sulfides and titratable organic compounds that produced by sulfate-reducing bacteria may have contributed to the alkalinity in water. This hypothesis is consistent with the significant decrease in sulfate concentration in all treatment media (see Table 9). The simultaneous decrease of Fe(II) and alkalinity within the media indicates the precipitation of ferrous carbonate (siderite) throughout the media. The precipitation of ferrous hydroxide should not be significant, as ferrous carbonate controls the solubility of $\mathrm{Fe}$ (II) (i.e., siderite is more stable) at near neutral pH (observed $\mathrm{pH}$ was around 7.5 for all the treatment media) (Table 8).

Table 9. Influent and effluent sulfate concentrations

\begin{tabular}{|c|c|c|c|c|}
\hline \multirow{2}{*}{$\begin{array}{l}\text { Date of } \\
\text { Sampling }\end{array}$} & \multirow{2}{*}{$\begin{array}{c}\text { Influent } \\
\text { concentration } \\
(\mathrm{mg} / \mathrm{L})\end{array}$} & \multicolumn{3}{|c|}{ Effluent concentration $(\mathrm{mg} / \mathrm{L})$} \\
\hline & & Peerless & Master Builders & Palladized iron \\
\hline 05/03/96 & 400 & 150 & 125 & 375 \\
\hline 05/09/96 & 400 & 150 & $125 / 75^{a}$ & $275 / 250^{a, b}$ \\
\hline $05 / 30 / 96$ & 375 & 175 & 125 & off-line \\
\hline $\begin{array}{l}{ }^{\circ} \mathrm{F} \\
\text { in sulfate } \\
\text { treatment }\end{array}$ & $\begin{array}{l}\text { measurements. } \\
\text { aitoring Colum } \\
\text { ements were tak } \\
\text { tion for } \mathrm{Pd} / \mathrm{Fe} \\
\text { the monitoring }\end{array}$ & $\begin{array}{l}\text { treatmen } \\
\text { may be d } \\
\text { an. }\end{array}$ & $\begin{array}{l}\text { isters unless not } \\
\text { the different resic }\end{array}$ & $\begin{array}{l}\text { The difference } \\
\text { nce times of the }\end{array}$ \\
\hline
\end{tabular}


Peerless Column

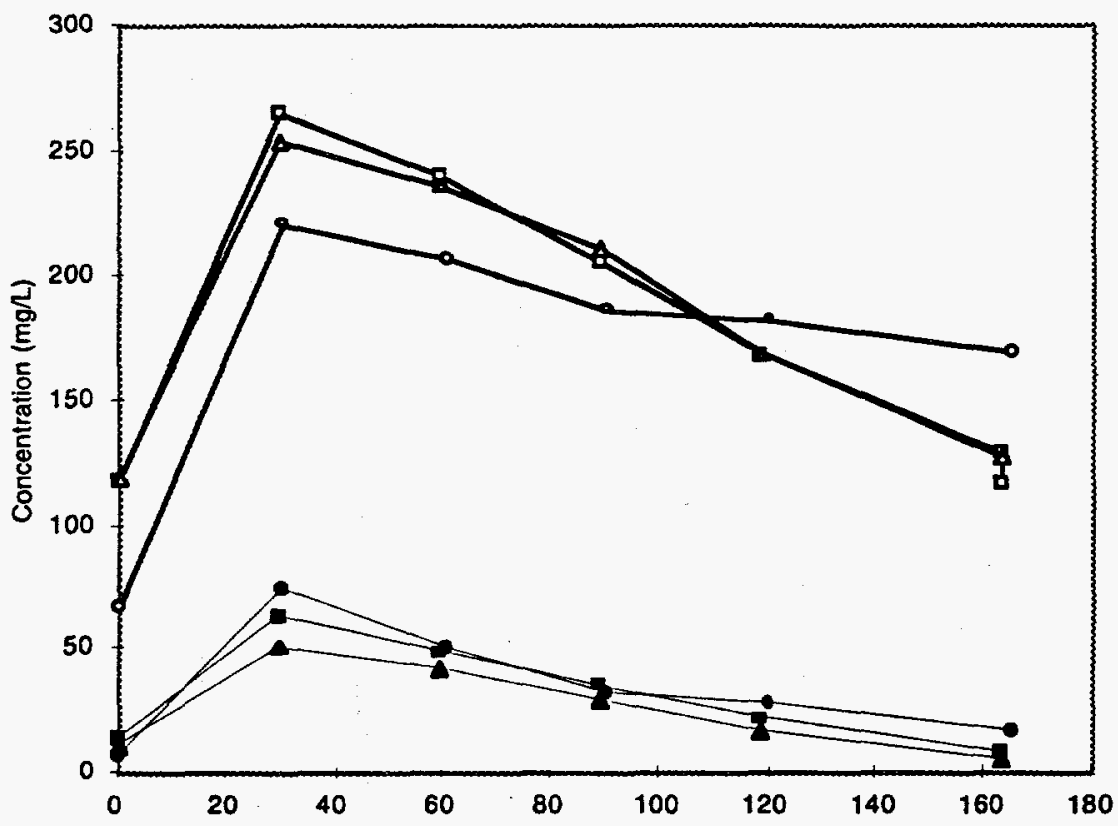

-Alkalinity, 3/28/96

- $-\mathrm{Fe}$ (II), 3/28/96

-Alkalinity, $4 / 12 / 96$

- $\mathrm{Fe}(\mathrm{II}), 4 / 12 / 96$

Alkalinity,8/22/96

$\rightarrow \mathrm{Fe}(\mathrm{II}), 8 / 22 / 96$

Fig. 29. Ferrous iron and alkalinity $\left(\mathrm{as}^{\mathrm{CaCO}}\right)$ in Peerless monitoring column as a function of residence time.

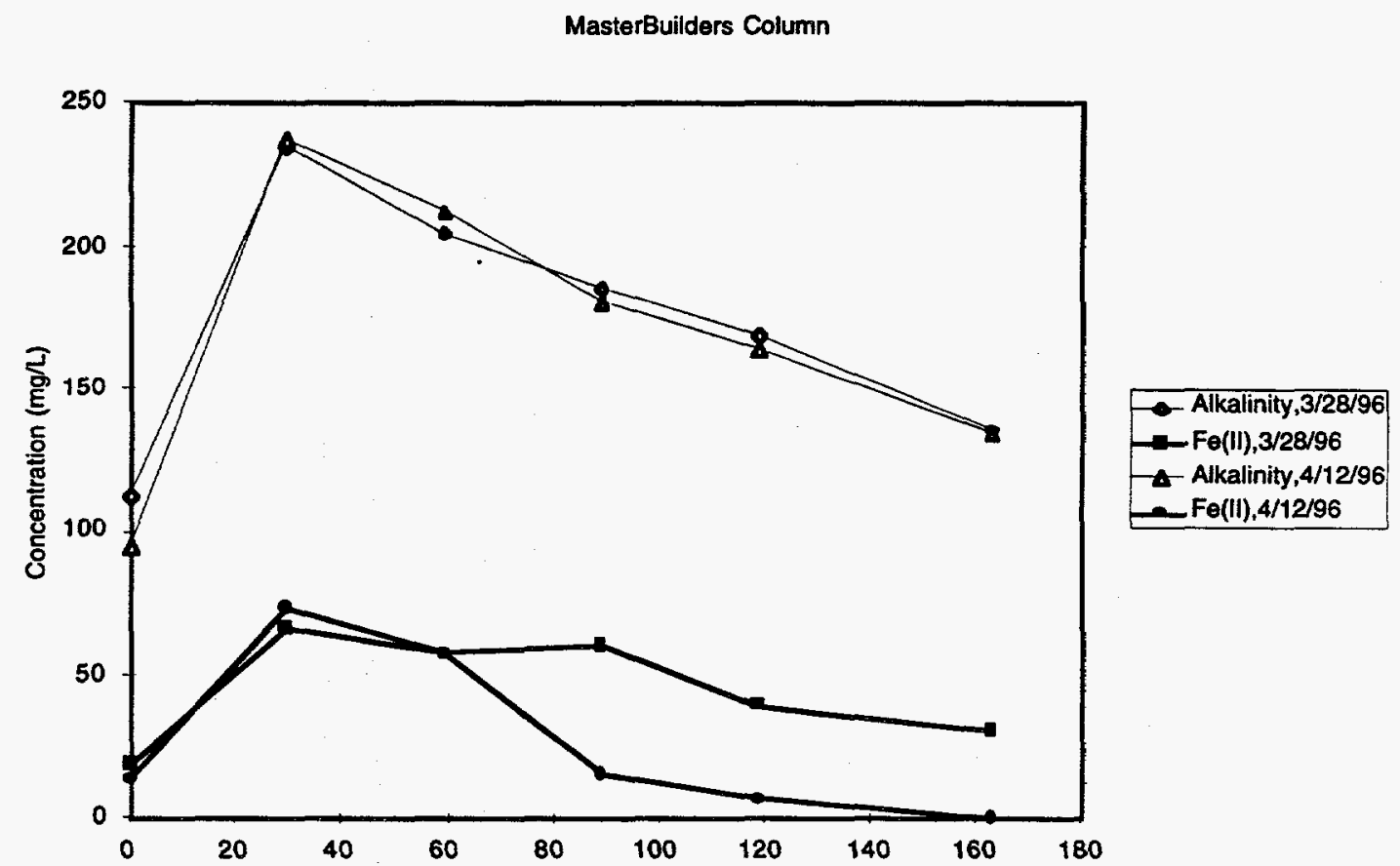

Fig. 30. Ferrous iron and alkalinity $\left(\mathrm{as} \mathrm{CaCO}_{3}\right)$ in Master Builders monitoring column. 
Palladized Iron Column

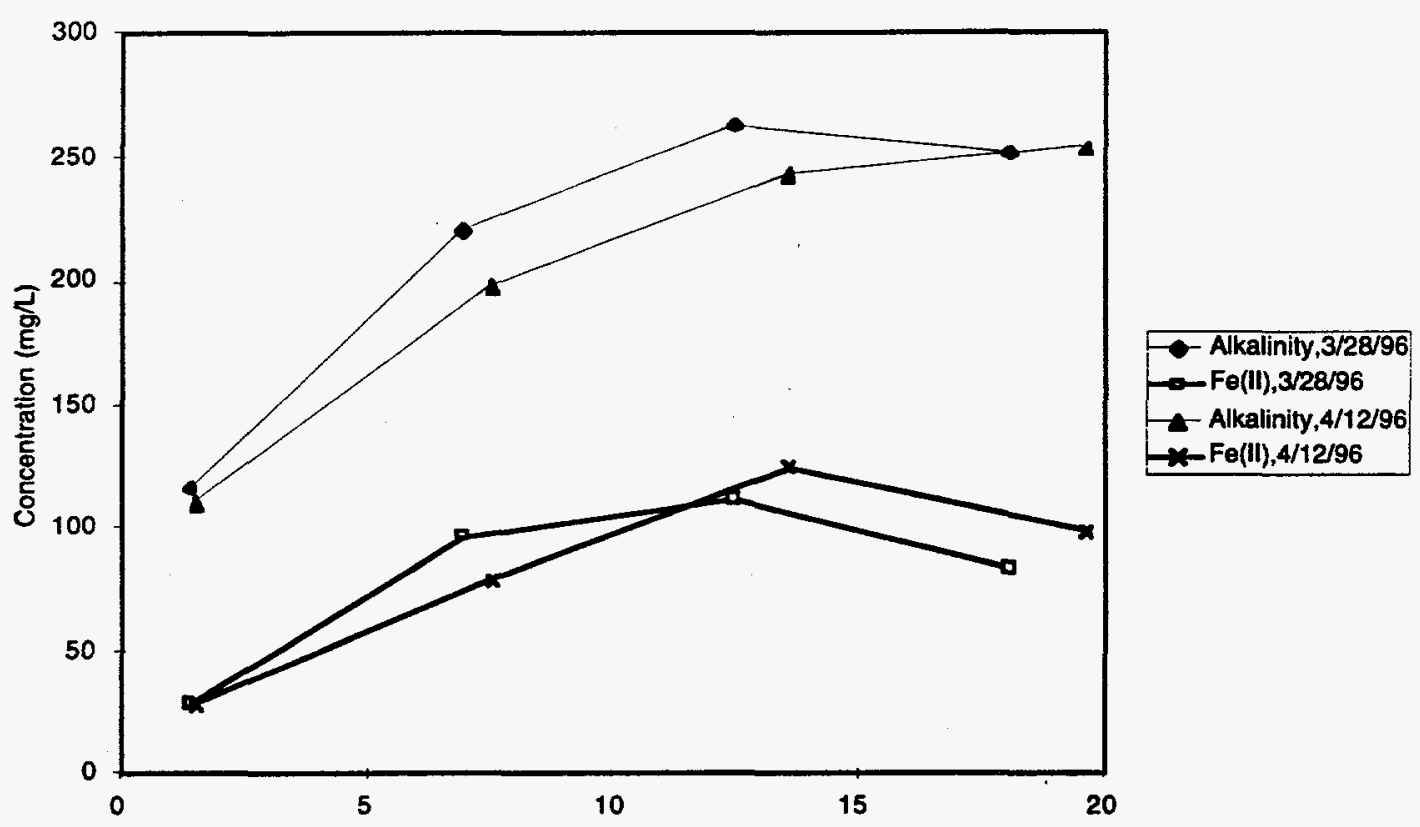

Fig. 31. Ferrous iron and alkalinity (as $\mathrm{CaCO}_{3}$ ) in palladized iron monitoring column.
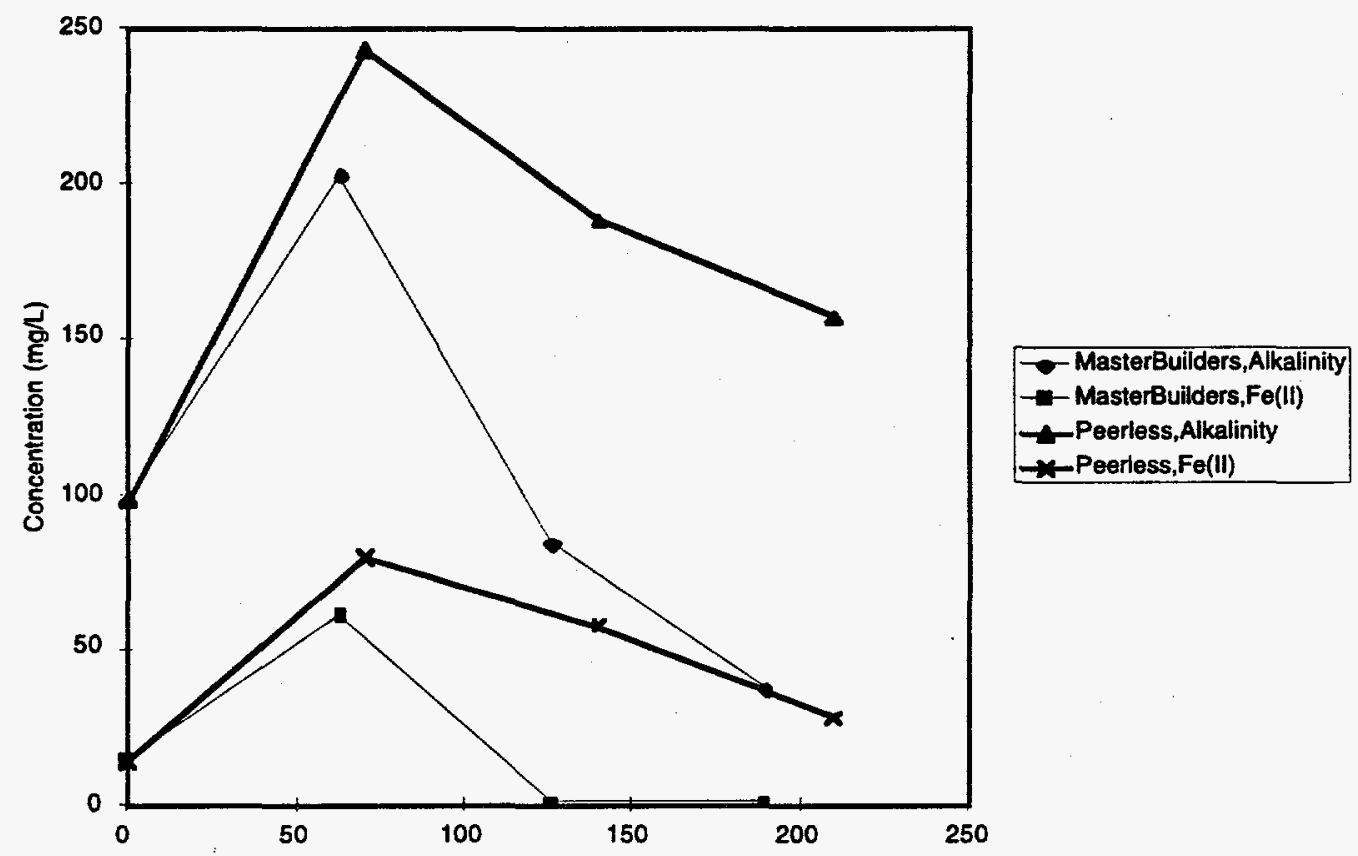

Fig. 32. Ferrous iron and alkalinity in Master Builders and Peerless treatment trains. Samples collected from ports between canisters on 3/28/96. 


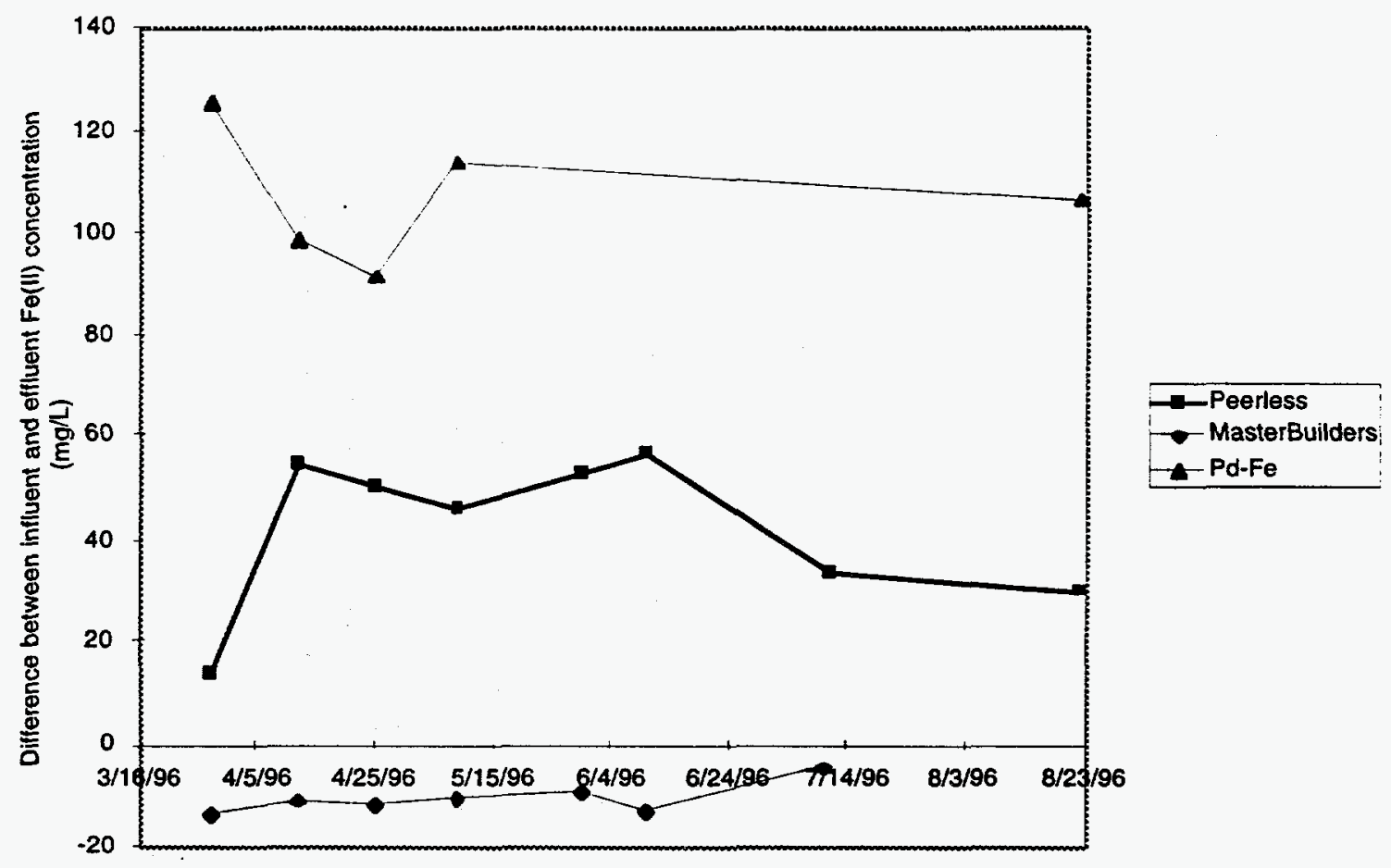

Fig. 33. Change in ferrous iron [Fe(II)] concentration in Peerless, Master Builders and palladized iron treatment trains. 


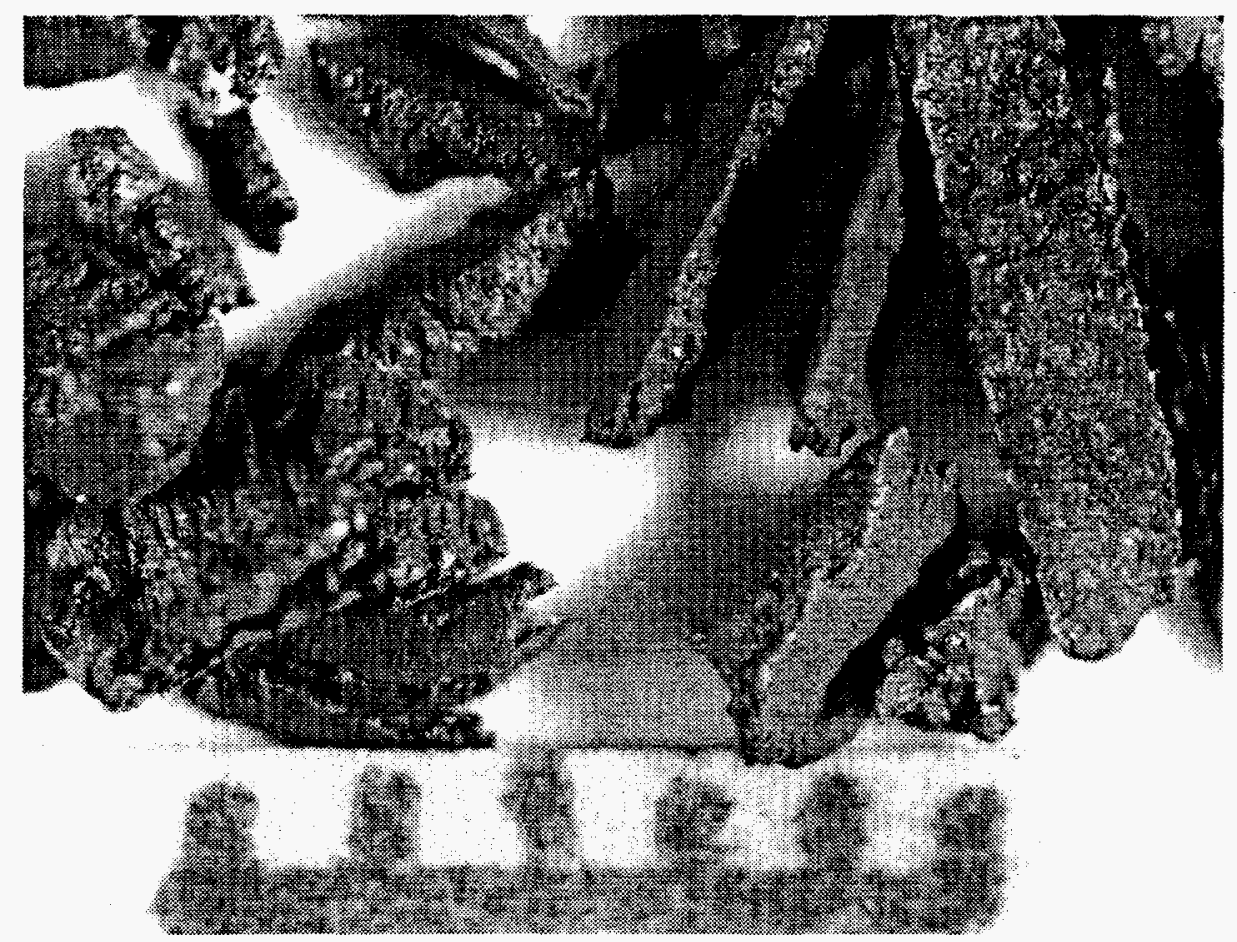

(a)

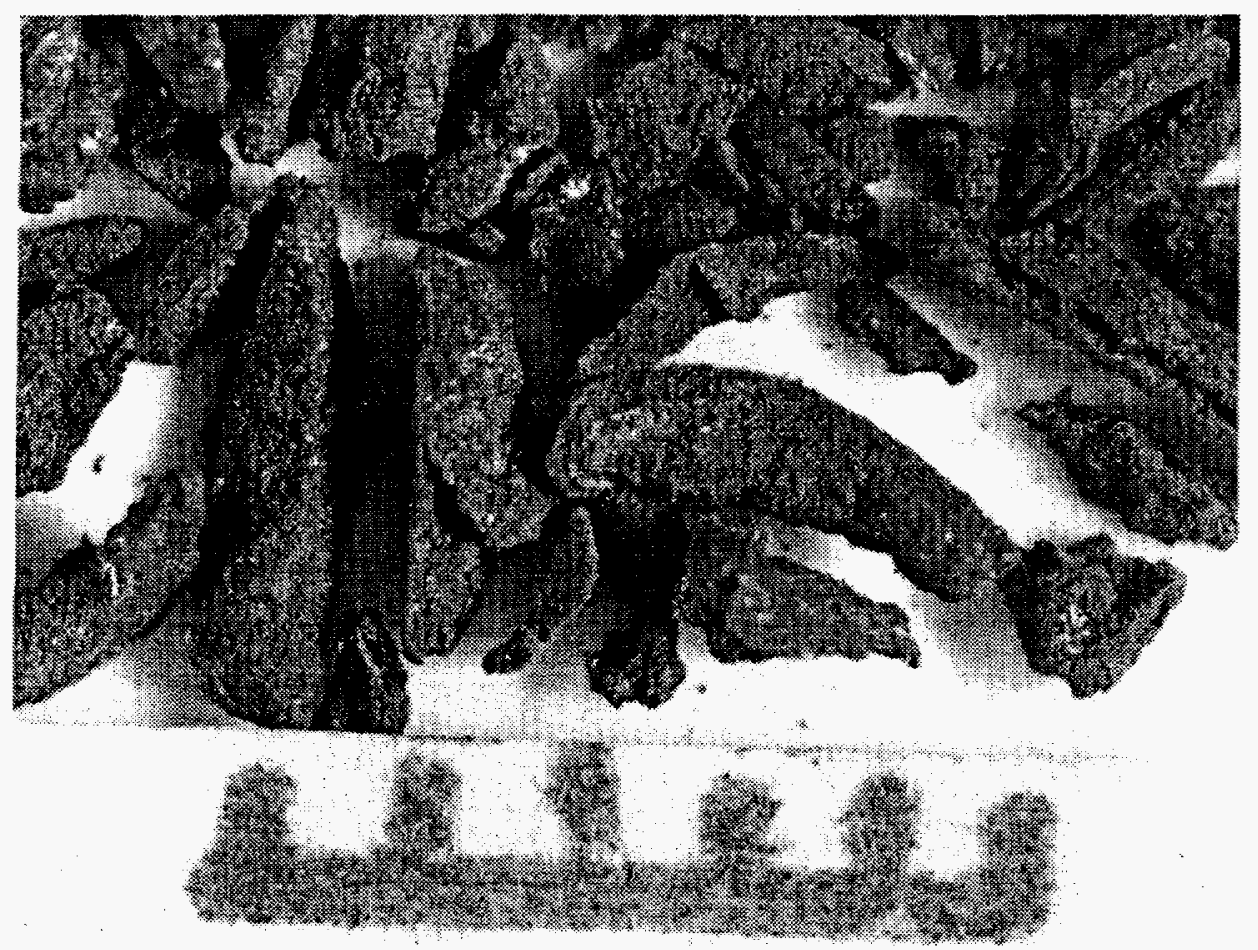

(b)

Fig. 34. Peerless iron filings before (a) and after approximately 5 months of use (b) at the X-625 facility. Each division on scale corresponds to $1 \mathrm{~mm}$. 


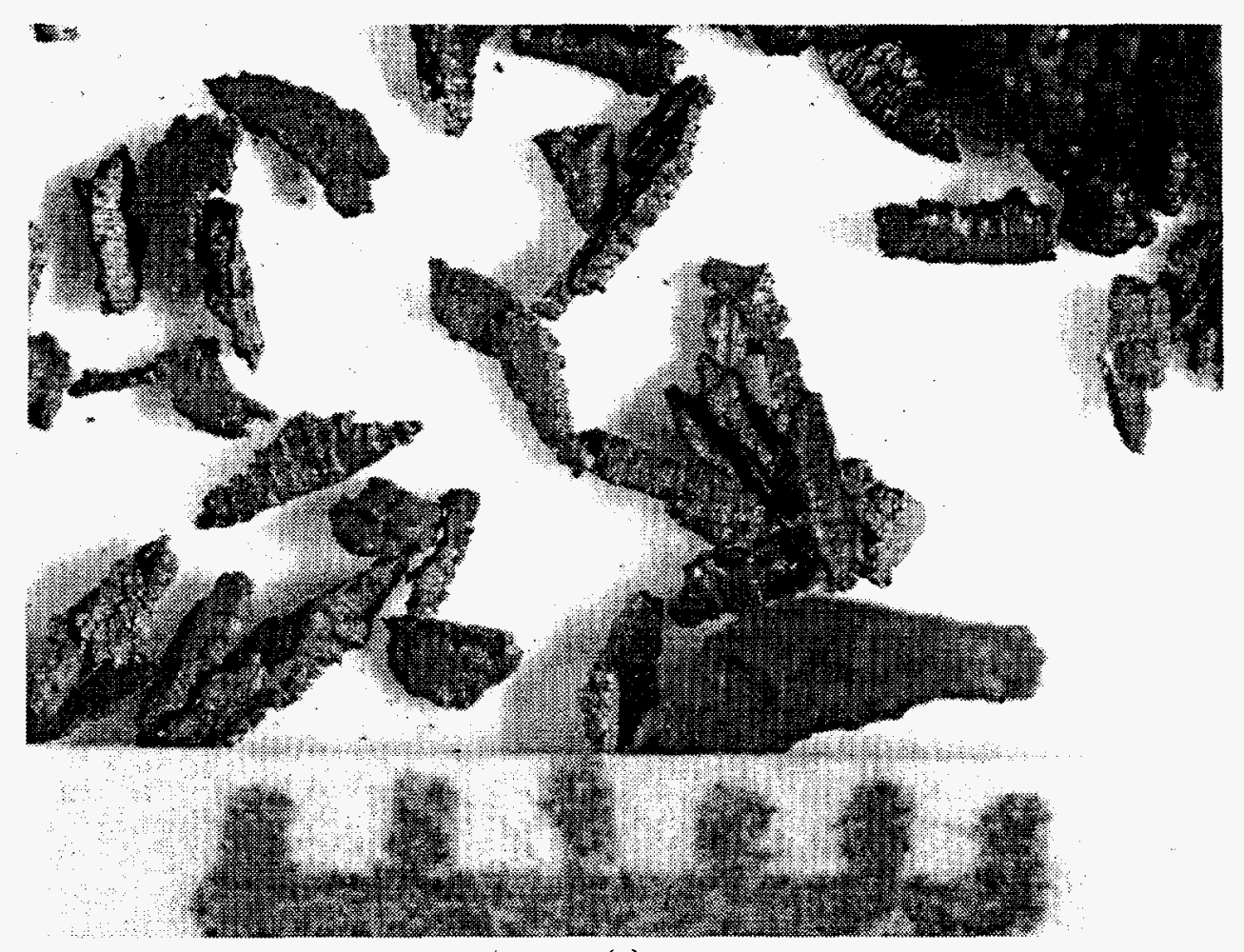

(a)

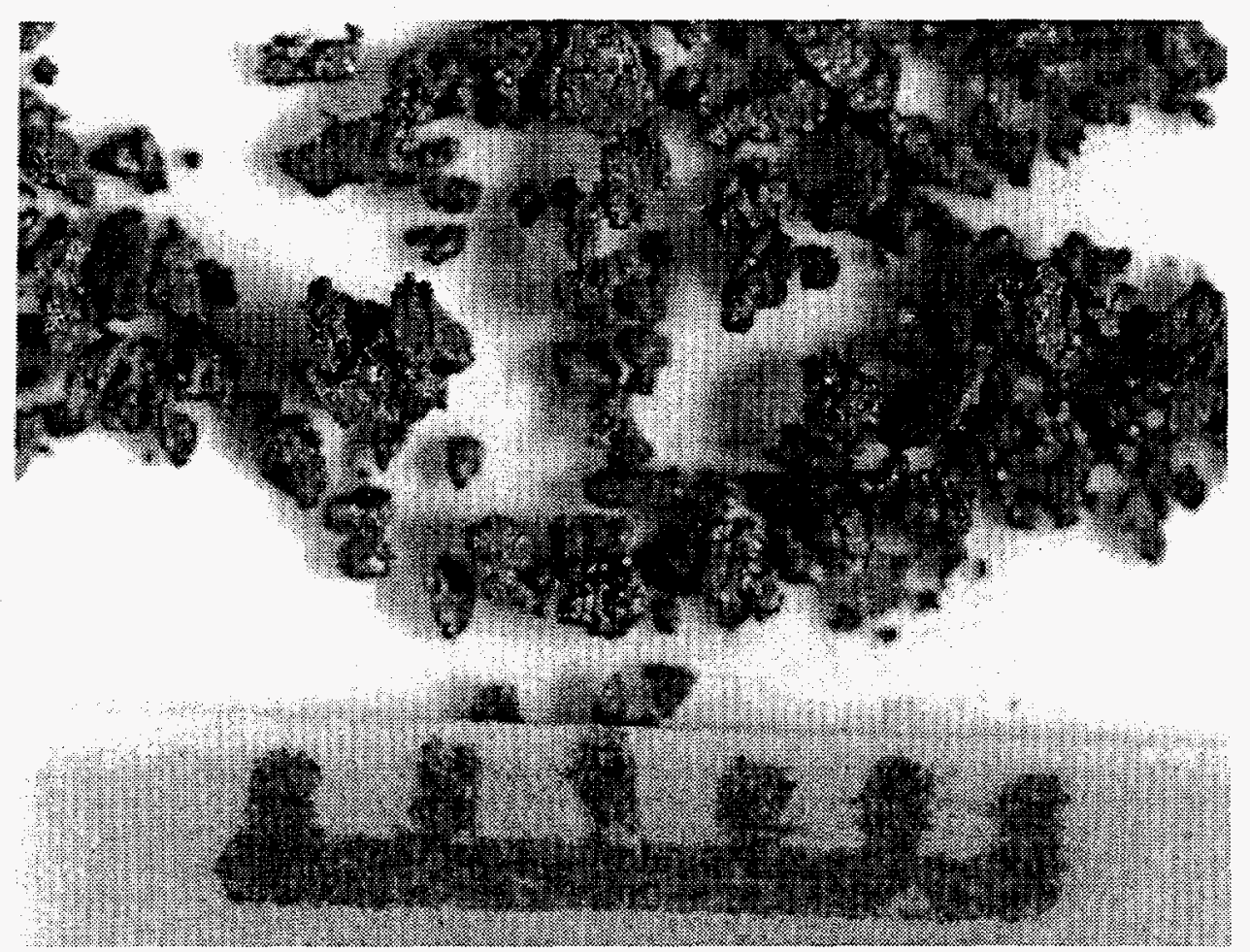

(b)

Fig. 35. Master Builders iron filings before (a) and after approximately 5 months of use (b) at the X-625 facility. Each division on scale corresponds to $1 \mathrm{~mm}$. 


\section{CONCLUSIONS}

Since the initial start-up in early March, 1996, the X-625 Groundwater Treatment Facility has been in operation for five months. Groundwater containing primarily TCE at levels of less than $200 \mathrm{ppb}$ has been flowing through the treatment media by gravity alone. Hence, passive groundwater remediation, as it occurs in reactive subsurface barriers, is simulated at the X-625 facility.

The reactive barrier materials currently being tested at the X-625 GTF are fine grade Master Builders iron filings (40-mesh), stock Peerless iron filings (-8+50-mesh), and palladized Fisher iron filings (40-mesh) provided by Johnson Matthey. For parallel comparison based on the initial degradation rates, equal volumes of iron filings (129 gal) were packed in the Master Builders and Peerless treatment canisters, while a much smaller volume of palladized iron filings was used $(12 \mathrm{gal})$. This volume of palladized iron - filings was estimated to be sufficient to reduce groundwater TCE concentrations to below $10 \mathrm{ppb}$ based on degradation rates obtained from previous laboratory experiments.

During start-up, problems with maintaining gravity flow through the system were resolved through modifications in system configuration and operational procedures. For example, hydrogen gas produced from the reductive dissociation of water by iron filings, accumulated in the drums and manifolds causing pressure build-up and flow stoppage through the system. To alleviate this problem, pressure release valves were installed on the drums to allow manual venting of accumulated gas. Routine operation of the system now includes drum venting whenever flow is slow or system pressures are high, as well as regular monitoring of the building atmosphere for hydrogen. Later on, however, adequate flow (>0.3 gpm) could not be maintained in the Master Builders train even with daily venting of the canisters. This was believed to be a result of clogging of the iron filings either from precipitation or bacteria build-up. Clogging was observed to be less severe in the Peerless treatment train, mainly due to the larger mesh size of these filings.

Initially, TCE removal was fastest (i.e., shortest half-life) in the palladized iron treatment media (half-life of $0.8 \mathrm{~min}$ after 1 day of operation in comparison with $\sim 10$ and $19 \mathrm{~min}$, respectively, for Master Builders and Peerless treatment media). The higher reactivity of the palladized filings was also reflected in higher effluent concentrations of ferrous iron. However, the TCE degradation rate in the palladized iron decreased with time, and the half-life of $18.8 \mathrm{~min}$ after 23 days of operation (treatment of 3345 pore volumes of water). Increases in half-lives for Master Builders and Peerless media in relation to initial values were also observed. The rapid removal in these treatment trains during the first week of system operation was articficial, as the reaction in these systems had not reached steady a state condition. The more rapid deterioration of palladized iron filings is attributed to the substantially higher number of pore volumes that have passed through this treatment train (about 3345 pore volumes compared with 331 pore volumes in the 
Peerless and Master Builder media). Poisoning of palladium by sulfides is another reason causing the reduction of treatment performance in the palladized iron treatment train. Regeneration methods were explored and should continue to be investigated in future studies.

The treatment by-products included cis-DCE, VC, and completely dechlorinated hydrocarbons (ethane and ethene). After several weeks of operation, cis-DCE and VC persisted throughout the treatment trains although the levels of these compounds were predominantly below $10 \%$ of the initial TCE concentrations.

Groundwater at X-625 appears to be well buffered because effluent $\mathrm{pH}$ values did not change significantly from the influent $\mathrm{pH}$. Under these near-neutral $\mathrm{pH}$ conditions, microbial activities were accelerated because abundant hydrogen gas produced from iron was available as an energy source for the microbes. Sulfate-reducing bacteria, built up on the reactive media, is postulated to have affected media reactivity and hydraulic conductivity. In addition, precipitation of ferrous minerals also lead to eventual clogging of the iron filings, resulting to heterogeneity in hydraulic conductivity (preferential flow) and groundwater bypassing the reactive barrier in in situ applications. Increases in pressure drop across the drums have been observed with time. Initially, the reduced hydraulic conductivity of the iron filings was attributed to biofouling. However, more recent observations of the iron filings in the canisters indicate cementation may be the main reason behind clogging. Relatively rapid rates of zero-valence iron consumption even under anoxic conditions was reflected by the high levels of aqueous $\mathrm{Fe}$ (II) measured in all the treatment trains, as well as by the physical appearance of the iron filings after only 5 months of usage. Therefore, aside from surface reactivity changes of iron filings, the life and long-term effectiveness of a reactive barrier will depend on the rate of iron consumption as well as media clogging.

Overall, based on sustained TCE degradation performance and suitable hydraulic characteristics (least clogging), stock Peerless iron filings appear to be the best reactive material tested to date at the X-625 GTF. However, due to recent changes in TCE degradation, it is recommended monitoring of the Peerless treatment train be continued. The Master Builder filings showed sustained reactivity but due to the small size, the filings were prone to clogging and iron particle cementation. The palladized iron filings had the most rapid degradation rates; however, their performance deteriorated after several thousand pore volumes of water were treated. The poor performance at extended water treatment is attributed to poisoning by sulfides that were produced by microbial reduction of sulfates present in the groundwater. The adverse effects of sulfides on palladium may be a problem specific to the high-sulfate levels in the groundwater underlying the X-625 facility.

The X-625 GTF is providing important field-scale and long-term data for the evaluation and design of reactive barriers at PORTS. The X-625 GTF is a unique facility not only 
because it is where site remediation is being performed, but it is also where research scientists and process engineers can test other promising reactive barrier materials. In addition, the data collected from X-625 GTF can be used to evaluate the technical and economic feasibility of replacing the activated carbon units in the pump-and-treat facilities at PORTS. Although preliminary conclusions have been made regarding the materials evaluated at the facility, continuous testing will be valuable to the research community as well as site owners who are interested in the development and implementation of passive reactive barrier technology for dechlorination with zerovalence iron. In the environmental remediation community, there is a misconception that reactive barriers are a permanent fix to environmental problems; once a reactive barrier is in place, no further work needs to be done and the contamination at the site is taken care of. This report shows that these reactive barrier do not have indefinite design lives and will require maintenance. The latter may include regeneration of the iron filings or periodic replacement of the reactive material. Routine monitoring of contaminant levels and geochemical parameters will allow determination of rates of clogging and change in media reactivity, thus predicting the life of a reactive barrier. 


\section{REFERENCES}

Gillham, R. W. and S. F. O'Hannesin. 1992. Metal-catalyzed abiotic degradation of halogenated organic compounds. IAH Conference on Modern Trends in Hydrogeology, Hamilton Ontario, Canada.

Gillham, R. W.; S. F. O'Hannesin. 1994. Enhanced degradation of halogenated aliphatics by zero-valent iron. Ground Water 32: 958-967.

Horney, D. P., P. D. McKenzie, J. J. Salvo, and T. M. Sivavec. 1995. Zero-valent iron treatability study for groundwater contaminated with chlorinated organic solvents at the Paducah, KY GDP Site. Report submitted to Lockheed Martin Energy Systems. GE Corporate Research and Development, Schenectady, NY.

Korte, N. E., R. Muftikian, C. Grittini, Q. Fernando, J.L. Clausen, and L. Liang. 1995. ORNL/MMES Research into remedial applications of zero-valence metals. Part 2: Bimetallic Enhancements. 209th National Meeting, American Chemical Society, Anaheim, CA, 1995; Vol. 35, No. 1, p. 752.

Liang, L., J. D. Goodlaxson, N. E. Korte, J. L. Clausen, and D. T. Davenport. 1995a. ORNL/MMES Research into remedial applications of zero-valence metals. Part 1: Laboratory analysis of reductive dechlorination of trichloroethylene. 209th National Meeting, American Chemical Society, Anaheim, CA, 1995; Vol. 35, No. 1, p. 728-731.

Liang, L. and J.D. Goodlaxson.1995b. "Kinetics and byproducts of reductive dechlorination of ground water TCE with zero-valence iron", Emerging technologies in hazardous waste management VII, extended abstract, pp46-49, American chemical Society, Atlanta, GA. 1995

Liang, L., N. E. Korte, J. D. Goodlaxson, J. Clausen, Q. Fernando, and R. Muftikian. 1997. Byproduct formation during the reduction of TCE by zero-valence iron and palladized iron. Ground Water Monitoring and Remediation, Winter: 122.

Matheson, L. J. and P. G. Tratnyek. 1994. Reductive dehalogenation of chlorinated methanes by iron metal. Environ. Sci. Technol. 28: 2045-2053.

Muftikian, R., Q. Fernando, and N. Korte. 1995. A method for the rapid dechlorination of low molecular weight chlorinated hydrocarbons in water. Water Research, 29: 2434-2439. 
O'Hannesin, S. F. and R. W. Gillham. 1992. A permeable reaction wall for in situ degradation of halogenated organic compounds. 45th Canadian Geotechnical Society Conference Toronto, Ontario, Canada.

O'Hannesin, S. F. 1993. A Field Demonstration of a Permeable Reaction Wall for the In Situ Abiotic Degradation of Halogenated Aliphatic Organic Compounds. M.S. Thesis, University of Waterloo, Ontario.

Puls, R. W., R. M. Powell, and C. J. Paul, 1995. In situ remediation of ground water contaminated with chromate and chlorinated solvents using zero-valent iron: a field study. 209th National Meeting, American Chemical Society, Anaheim, CA, Vol. 35, No. 1, p. 788.

Sivavec, T. M., D. P. Horney, 1995. Reductive dechlorination of chlorinated ethenes by iron metal. 209th National Meeting, American Chemical Society, Anaheim, CA, Vol. 35, No. 1, p. 695.

Vogan, J. L., J. K. Seaberg, B. Gnabasik, and S. F. O'Hannesin, 1994. Evaluation of in-situ groundwater remediation by metal enhanced reductive dehalogenation-laboratory column studies and groundwater flow modeling. presented at the 87th Annual meeting, Air \& Waste Management, Cincinnati, $\mathrm{OH}$. 


\section{APPENDIX \\ Volatile Organic Compounds in Influent and Effluent Streams}


Table A.1 Concentrations of trichloroethylene and dechlorination by-products in influent and effluent streams of the Peerless treatment train.

\begin{tabular}{|c|c|c|c|c|c|c|c|c|}
\hline \multirow[t]{2}{*}{$\begin{array}{l}\text { Sampling } \\
\text { Date }\end{array}$} & \multicolumn{4}{|c|}{$\begin{array}{l}\text { Influent concentration } \\
\qquad(p p b)^{a}\end{array}$} & \multicolumn{4}{|c|}{$\begin{array}{c}\text { Effluent concentration } \\
(p p b)^{a}\end{array}$} \\
\hline & $\begin{array}{l}\text { Ethene/ } \\
\text { Ethane }\end{array}$ & $\begin{array}{l}\text { Vinyl } \\
\text { Chloride }\end{array}$ & $\begin{array}{l}\text { cis-1,2- } \\
\text { Dichloro- } \\
\text { ethene }\end{array}$ & $\begin{array}{l}\text { Trichloro- } \\
\text { ethylene }\end{array}$ & $\begin{array}{l}\text { Ethene/ } \\
\text { Ethane }\end{array}$ & $\begin{array}{l}\text { Vinyl } \\
\text { Chloride }\end{array}$ & $\begin{array}{c}\text { cis-1,2-" } \\
\text { Dichloro- } \\
\text { ethene }\end{array}$ & $\begin{array}{l}\text { Trichloro- } \\
\text { ethylene }\end{array}$ \\
\hline $3 / 6 / 96$ & 1.1 & 1.3 & $\mathrm{nd}$ & 170.1 & 4.5 & 2.5 & nd & nd \\
\hline $3 / 12 / 96$ & 0.5 & 0.9 & nd & 165.2 & 14.3 & 3.0 & nd & nd \\
\hline $3 / 28 / 96$ & nd & 0.9 & $\mathrm{nd}$ & 156.7 & 11.6 & 3.3 & nd & nd \\
\hline $4 / 11 / 96$ & nd & 0.8 & 4.1 & 139.6 & 10.8 & 2.3 & 7.1 & 3.1 \\
\hline $4 / 23 / 96$ & nd & 1.0 & 4.5 & 121.6 & 10.7 & 2.0 & 6.1 & n \\
\hline $5 / 7 / 96$ & 0.7 & 1.0 & 3.5 & 108.8 & 9.0 & 1.8 & 5.1 & nd \\
\hline $5 / 28 / 96$ & 0.1 & 0.9 & 2.7 & 98.2 & 5.9 & 1.4 & 5.9 & 3.8 \\
\hline $6 / 6 / 96$ & 1.8 & 1.6 & 3.1 & 87.7 & 7.5 & 1.8 & 5.1 & nd \\
\hline $6 / 19 / 96$ & 1.1 & 2.6 & 2.7 & 123.2 & 7.0 & 2.4 & 5.0 & nd \\
\hline $7 / 9 / 96$ & $\mathrm{nd}$ & nd & 3.0 & 104.5 & 4.3 & 1.1 & 5.6 & nd \\
\hline $7 / 31 / 96$ & nd & nd & 2.5 & 108.4 & 5.3 & 2.0 & nd & nd \\
\hline $8 / 7 / 96$ & $n d$ & $\mathrm{nd}$ & 2.6 & 78.7 & 5.7 & 2.4 & 3.5 & nd \\
\hline $8 / 20 / 96$ & nd: & nd & 2.2 & 68.3 & 6.6 & ndi & nd & nd \\
\hline
\end{tabular}

${ }^{\mathrm{a}} \mathrm{nd}=$ not detected

Table A.2 Concentrations of trichloroethylene and dechlorination by-products in influent and effluent streams of the Master Builders treatment train.

\begin{tabular}{|c|c|c|c|c|c|c|c|c|}
\hline \multirow[t]{2}{*}{$\begin{array}{l}\text { Sampling } \\
\text { Date }\end{array}$} & \multicolumn{4}{|c|}{$\begin{array}{l}\text { Influent concentration } \\
(\mathrm{ppb})^{\mathrm{a}}\end{array}$} & \multicolumn{4}{|c|}{$\begin{array}{l}\text { Effluent concentration } \\
(p p b)^{a}\end{array}$} \\
\hline & $\begin{array}{l}\text { Ethene/ } \\
\text { Ethane }\end{array}$ & $\begin{array}{l}\text { Vinyl } \\
\text { Chloride }\end{array}$ & $\begin{array}{c}\text { cis-1,2-" } \\
\text { Dichloro- } \\
\text { ethene }\end{array}$ & $\begin{array}{l}\text { Trichloro- } \\
\text { ethylene }\end{array}$ & $\begin{array}{l}\text { Ethene/ } \\
\text { Ethane }\end{array}$ & $\begin{array}{l}\text { Vinyl } \\
\text { Chloride }\end{array}$ & $\begin{array}{l}\text { cis-1,2-" } \\
\text { Dichloro- } \\
\text { ethene }\end{array}$ & $\begin{array}{l}\text { Trichloro- } \\
\text { ethylene }\end{array}$ \\
\hline $3 / 6 / 96$ & 1.1 & 1.2 & nd & 168.7 & nd & nd & nd & nd \\
\hline $3 / 12 / 96$ & 0.5 & 0.9 & 9.8 & 165.2 & nd & nd & nd & nd \\
\hline $3 / 28 / 96$ & 0.5 & 1.0 & 10.1 & 170.6 & nd & nd & nd & nd \\
\hline $4 / 11 / 96$ & nd & 0.8 & 4.0 & 138.6 & 8.3 & nd & nd & nd \\
\hline $4 / 23 / 96$ & nd & 1.0 & 4.6 & 123.8 & 10.4 & nd & nd & nd \\
\hline $5 / 7 / 96$ & 0.8 & 1.0 & 3.5 & 110.9 & 9.0 & nd & nd & nd \\
\hline $5 / 28 / 96$ & nd & 0.9 & 2.8 & $99.9^{\circ}$ & nd & nd & nd & nd \\
\hline $6 / 6 / 96$ & 1.8 & 1.6 & 3.2 & 89.1 & 13.8 & 2.3 & nd & nd \\
\hline $6 / 19 / 96$ & 1.1 & 8.6 & 2.7 & $122.0^{\circ}$ & 8.5 & 1.6 & 3.6 & 4.7 \\
\hline $7 / 9 / 96$ & nd & nd & 3.0 & 105.2 & 7.9 & 1.3 & 4.4 & 8.4 \\
\hline $7 / 31 / 96$ & 0.4 & 4.1 & 3.4 & 99.5 & 11.3 & 4.6 & 3.8 & 6.0 \\
\hline $8 / 7 / 96$ & nd & nd & 2.6 & 79.8 & 8.3 & 1.2 & 3.1 & nd \\
\hline
\end{tabular}


Table A.3 Concentrations of trichloroethylene and dechlorination by-products in influent and effluent streams of the palladized iron treatment train.

\begin{tabular}{|c|c|c|c|c|c|c|c|c|}
\hline \multirow[t]{2}{*}{ Sampling } & \multicolumn{4}{|c|}{$\begin{array}{c}\text { Influent concentration } \\
(\mathrm{ppb})^{\mathrm{a}}\end{array}$} & \multicolumn{4}{|c|}{$\begin{array}{c}\text { Effluent concentration } \\
(\mathrm{ppb})^{\mathrm{a}}\end{array}$} \\
\hline & $\begin{array}{l}\text { Ethene/ } \\
\text { Ethane }\end{array}$ & $\begin{array}{l}\text { Vinyl } \\
\text { Chloride }\end{array}$ & $\begin{array}{l}\text { cis-1,2- } \\
\text { Dichloro- } \\
\text { ethene }\end{array}$ & $\begin{array}{l}\text { Trichloro- } \\
\text { ethylene }\end{array}$ & $\begin{array}{l}\text { Ethene/ } \\
\text { Ethane }\end{array}$ & $\begin{array}{l}\text { Vinyl } \\
\text { Chloride }\end{array}$ & $\begin{array}{c}\text { cis-1,2- } \\
\text { Dichloro- } \\
\text { ethene }\end{array}$ & $\begin{array}{l}\text { Trichloro- } \\
\text { ethylene }\end{array}$ \\
\hline $3 / 6 / 96$ & 1.1 & 1.3 & nd & 170.1 & 49.9 & nd & $\mathrm{nd}$ & nd \\
\hline $3 / 12 / 96$ & 0.5 & 0.9 & nd & 165.2 & 32.4 & 7.3 & nd & nd \\
\hline $3 / 28 / 96$ & nd & 0.9 & 4.2 & 156.7 & 9.9 & 5.9 & 5.4 & 77.9 \\
\hline $4 / 11 / 96$ & nd & 0.8 & 4.0 & 136.6 & 4.4 & 2.9 & 6.4 & 66.4 \\
\hline $4 / 23 / 96$ & nd & 1.0 & 4.4 & 120.9 & 4.8 & 2.9 & 6.8 & 30.6 \\
\hline $5 / 7 / 96$ & 0.8 & 1.0 & 3.6 & 110.9 & 5.5 & 2.5 & 7.2 & 8.7 \\
\hline \multicolumn{9}{|c|}{ Treatment train was taken off-line on May 17,1996 and put back on-line on July $18,1996}$. \\
\hline $7 / 31 / 96$ & nd & nd & 2.5 & 108.4 & 2.7 & 2.0 & 4.6 & 35.8 \\
\hline $8 / 7 / 96$ & nd & nd & 2.6 & 75.0 & 2.3 & 2.7 & 3.9 & 63.7 \\
\hline $8 / 20 / 96$ & nd & nd & 2.4 & 79.1 & 1.9 & 2.5 & 4.0 & 18.7 \\
\hline
\end{tabular}




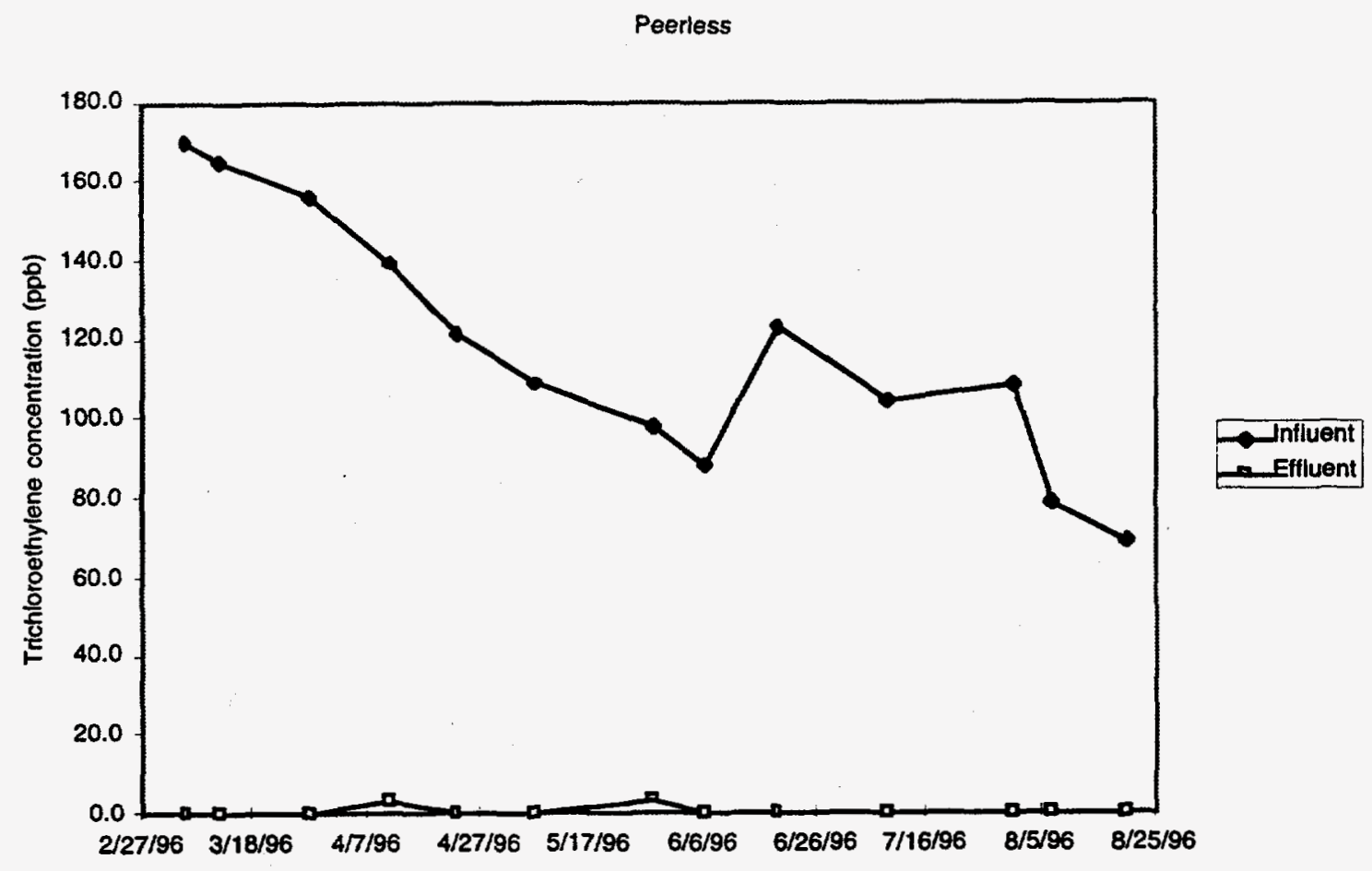

Fig. A.1. Trichloroethylene concentrations in influent and effluent streams of the Peerless treatment train. 
Peeriess: Dechlorination By-products in Influent Stream

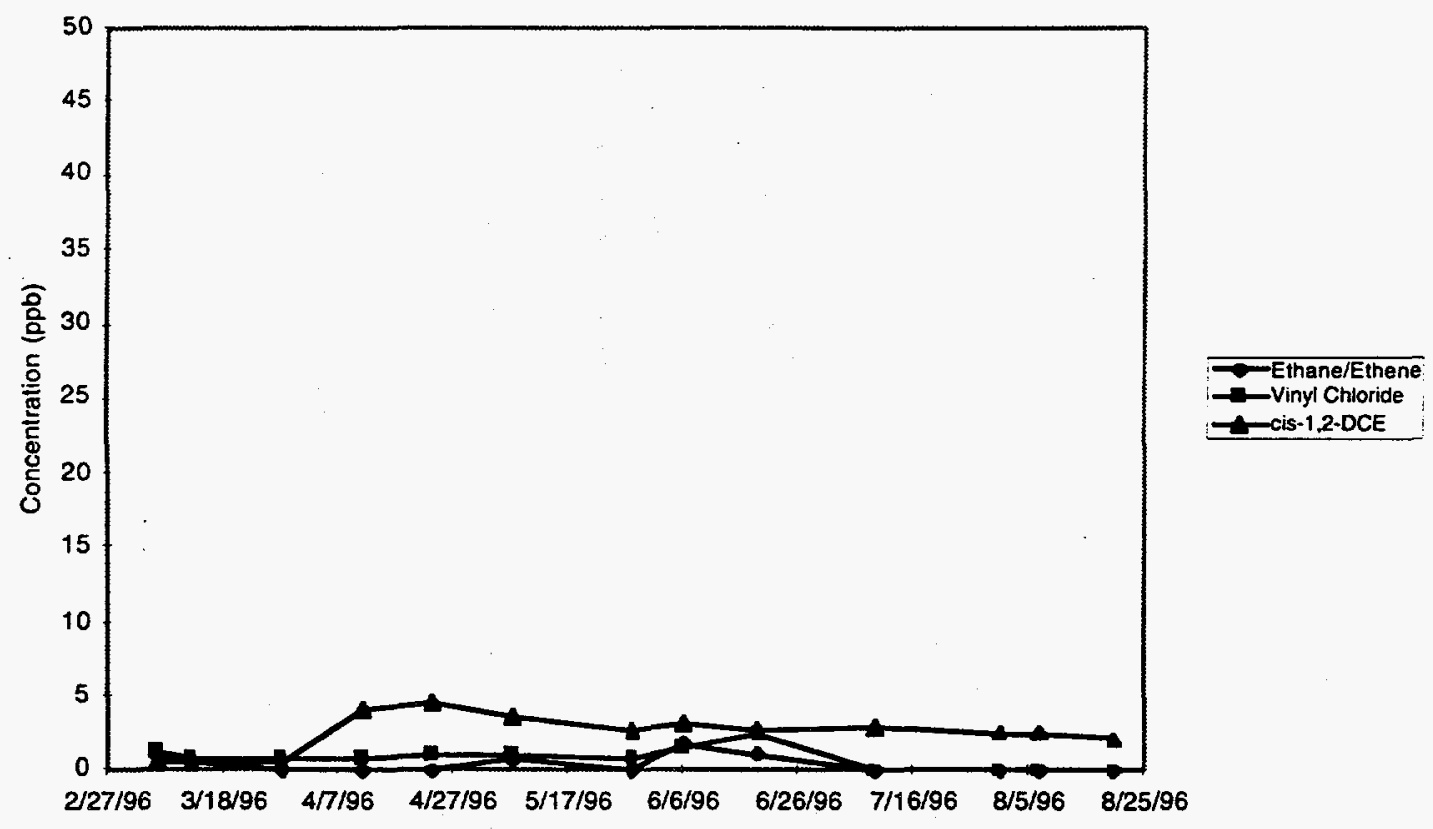

(a)

Peerless: Dechlorination By-products in Effluent Stream

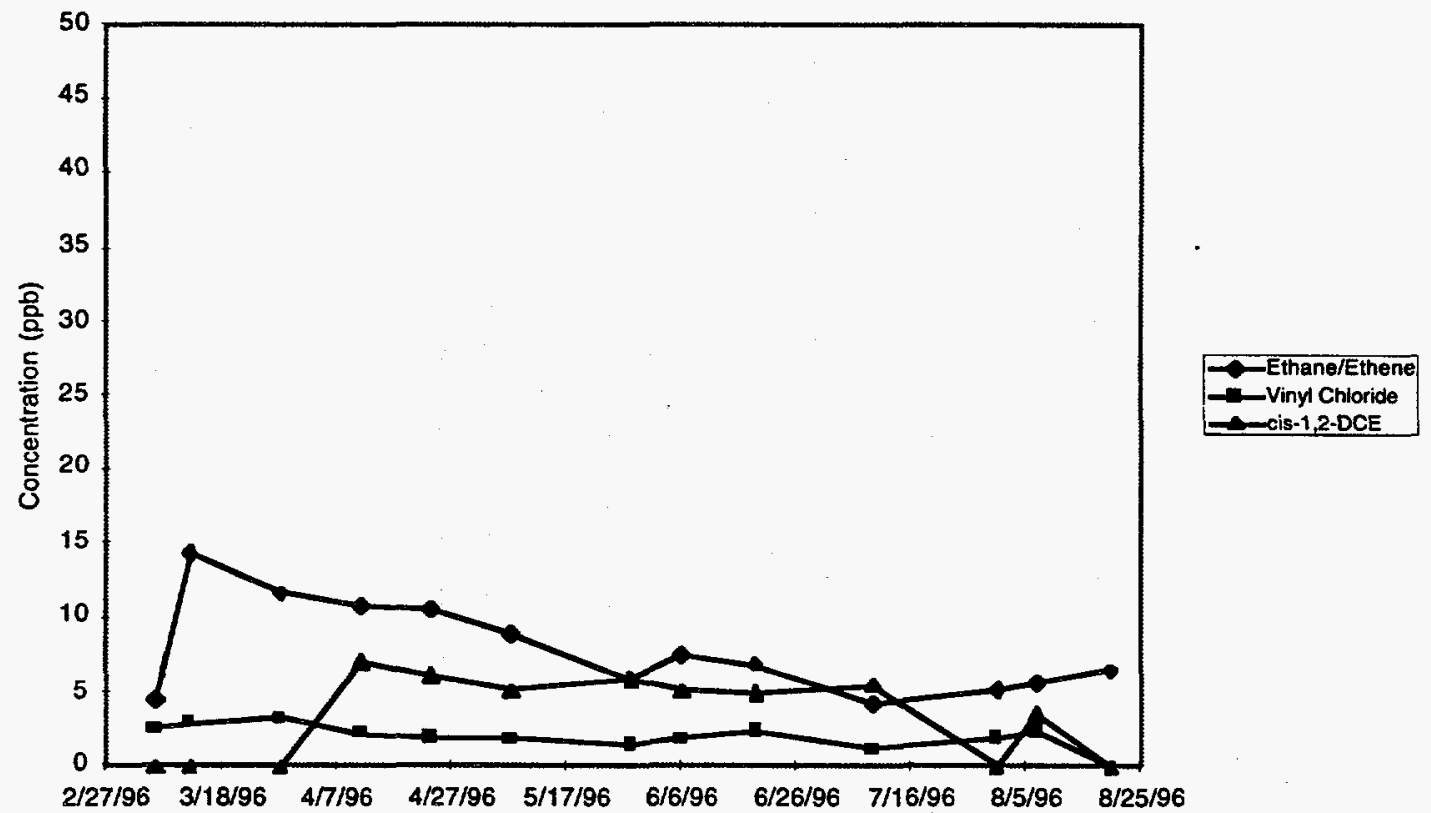

(b)

Fig. A.2 Concentration of ethane/ethene, vinyl chloride and cis-1,2-dichloroethene (DCE) in (a) influent and (b) effluent streams of the Peerless treatment train. 
MasterBuilders

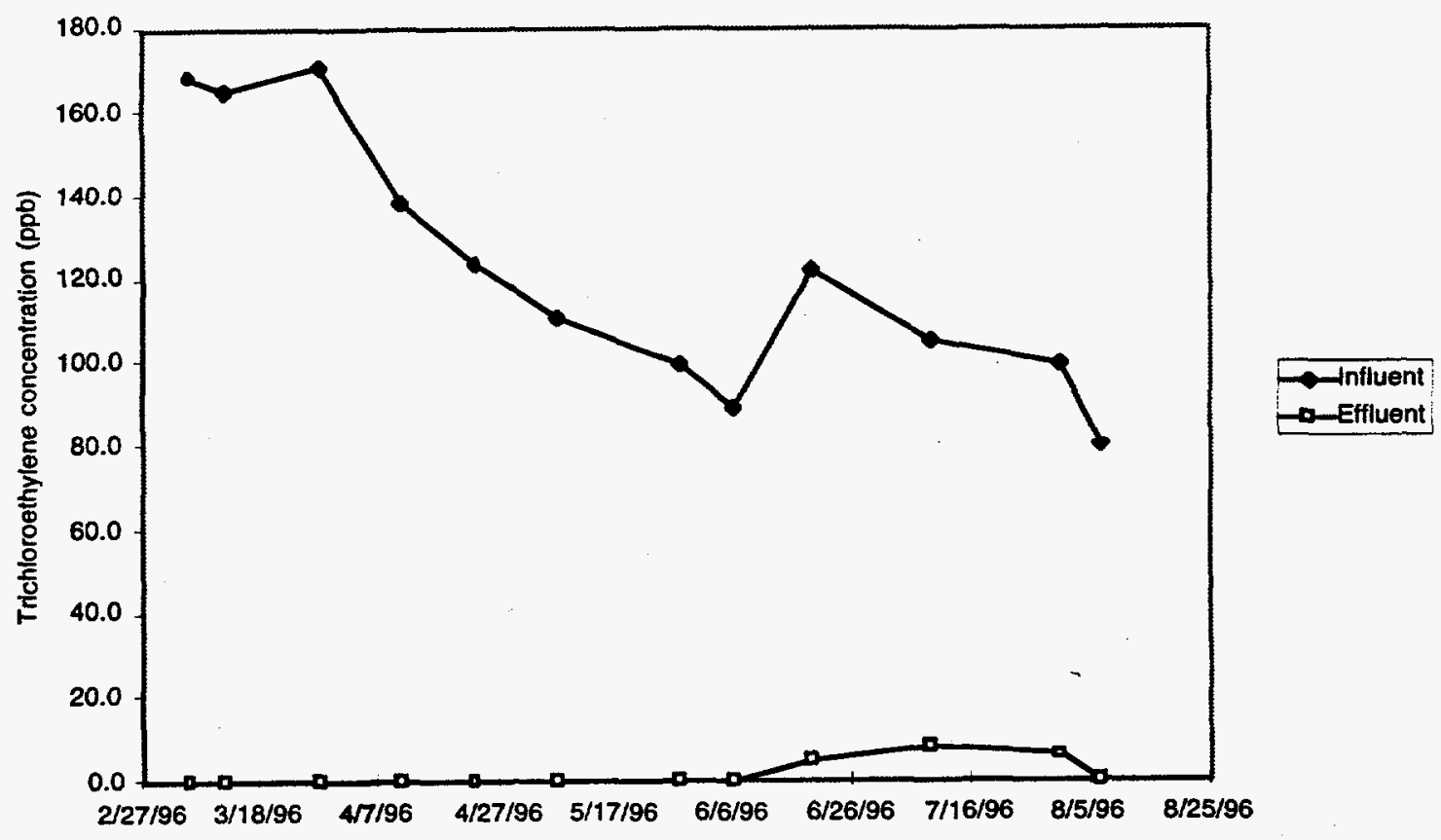

Fig. A.3. Trichloroethylene concentrations in influent and effluent streams of the Master Builders treatment train. 
MasterBuilders: Dechlorination By-products in Influent Stream

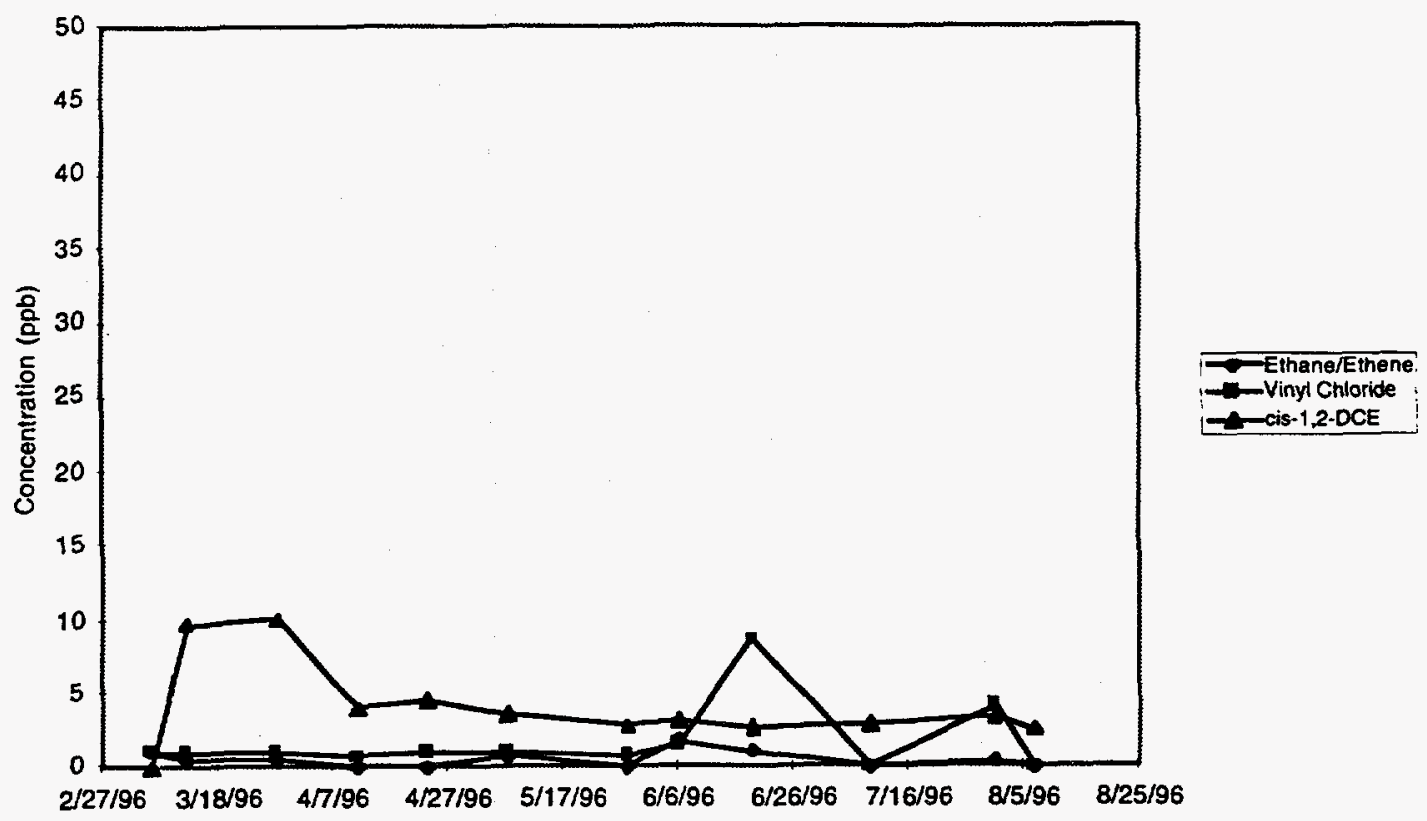

(a)

MasterBuilders: Dechlorination By-products in Effluent Stream

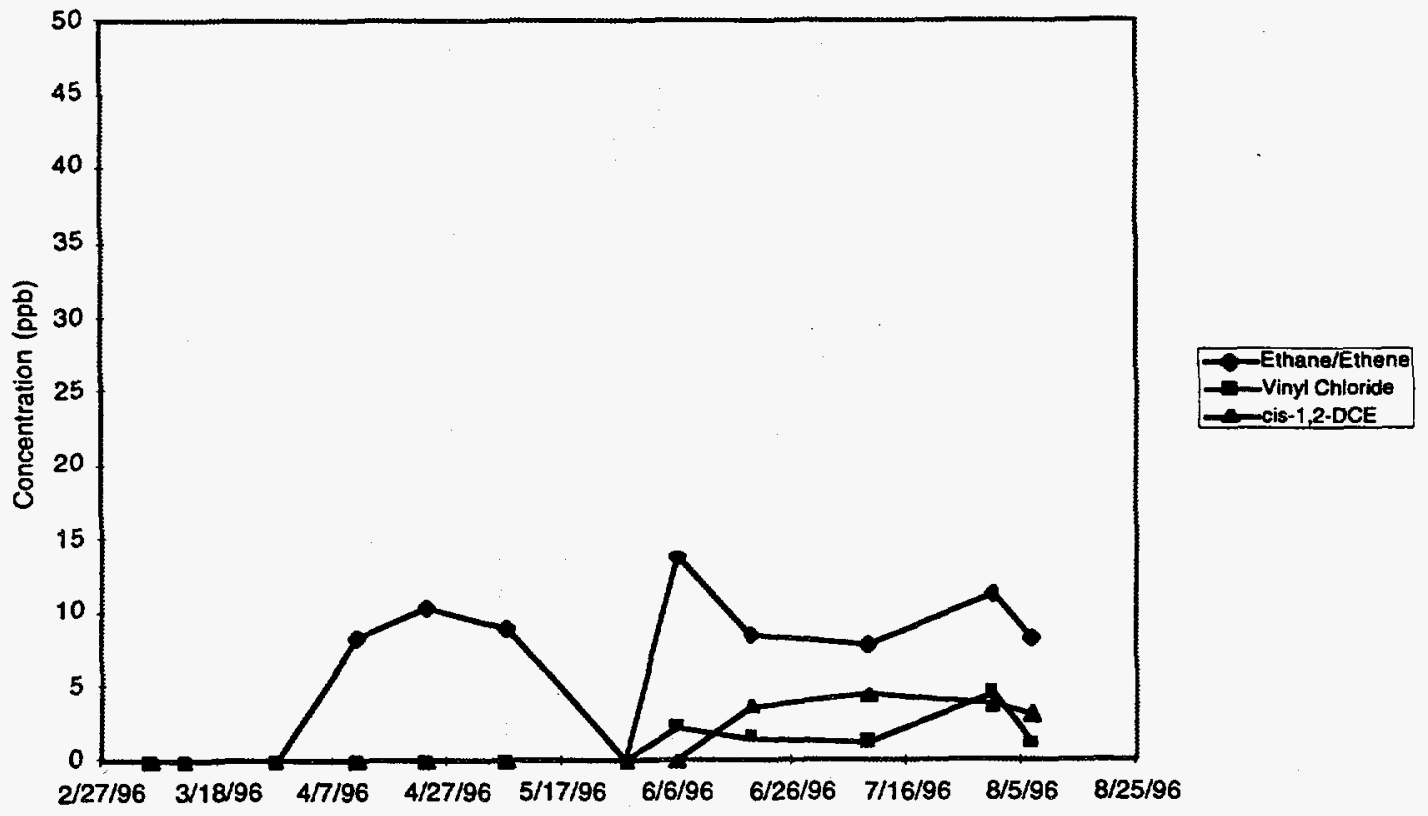

(b)

Fig. A.4 Concentration of ethane/ethene, vinyl chloride and cis-1,2-dichloroethene (DCE) in (a) influent and (b) effluent streams of the Master Builders treatment train. 
Palladized iron

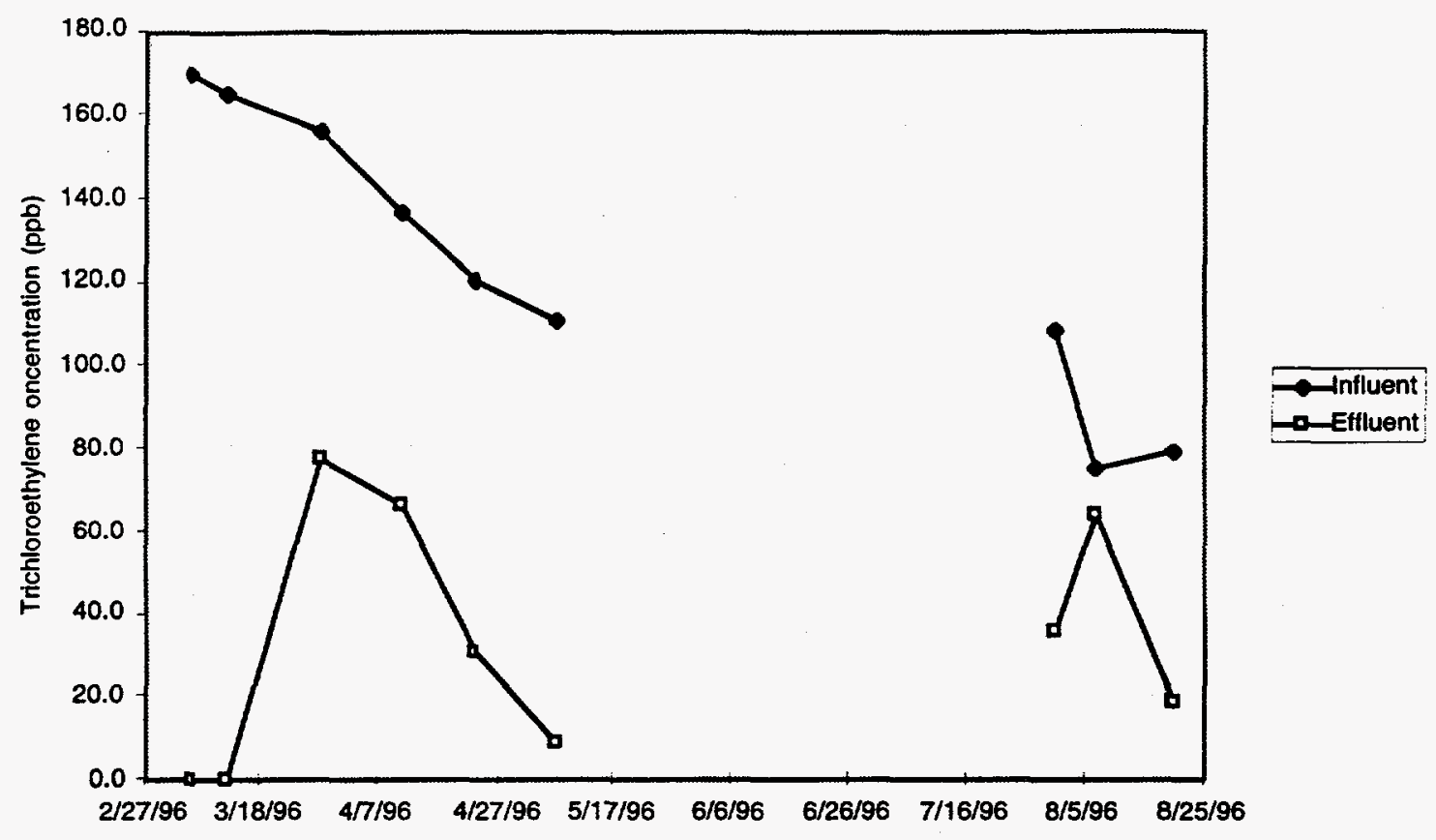

Fig. A.5. Trichloroethylene concentrations in influent and effluent streams of the palladized iron treatment train. This train was shut down on May 17 and put back on-line on July 18. 
Palladized Iron: Dechlorination By-products in Influent Stream

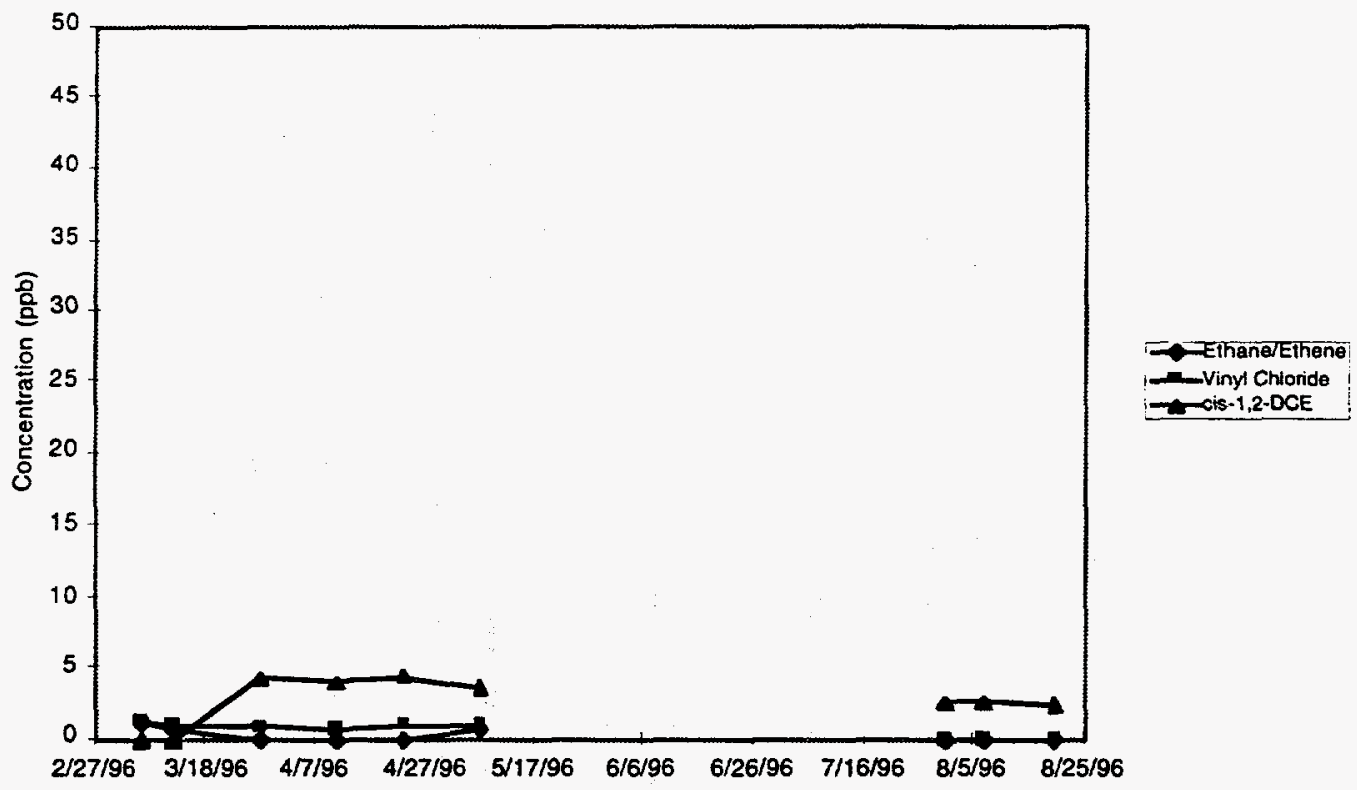

(a)

Palladized Iron: Dechlorination By-products in Effluent Stream

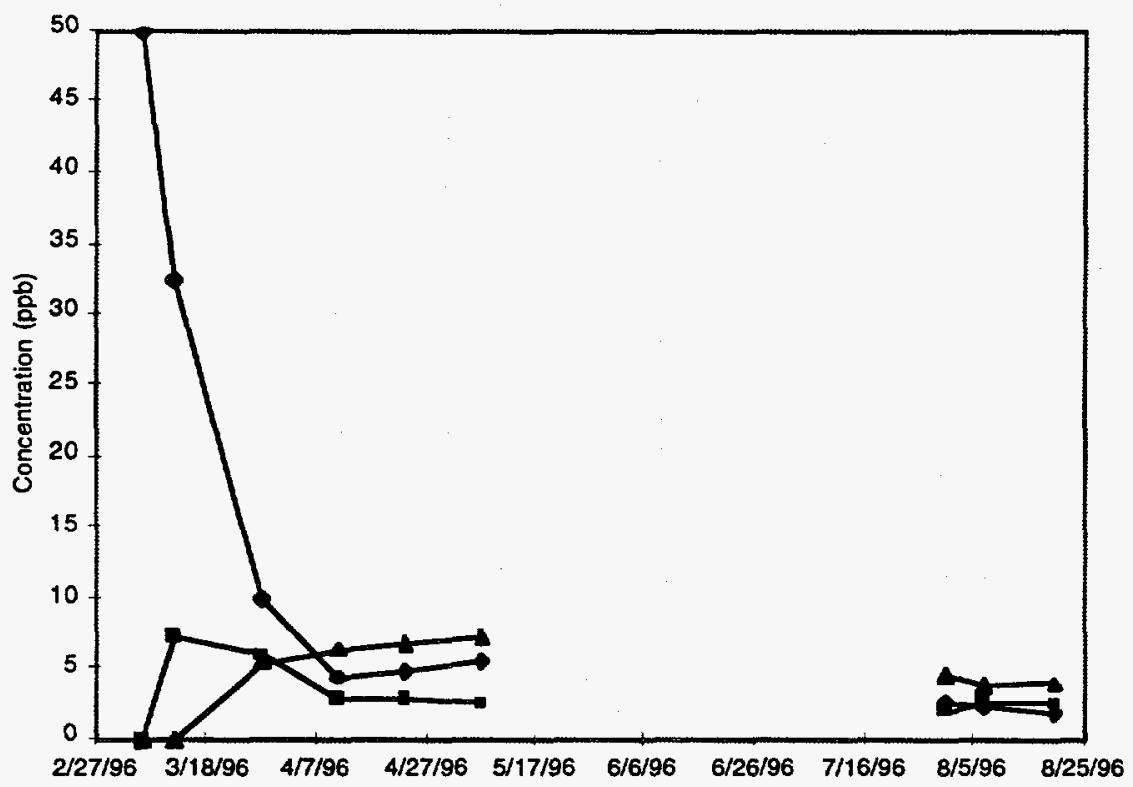

(b)

Fig. A.6 Concentration of ethane/ethene, vinyl chloride and cis-1,2-dichloroethene (DCE) in (a) influent and (b) effluent streams of the palladized iron treatment train. This train was shut down on May 17 and put back on-line on July 18. 


\title{
INTERNAL DISTRIBUTION
}

\author{
J. H. Cushman \\ D. E. Fowler \\ M. J. Dickey \\ A. F. Diefendorf \\ B. $\mathrm{Gu}$ \\ S. G. Hildebrand \\ G. K. Jacobs \\ P. Kanciruk \\ (5) N. E. Korte \\ (6) S. Y. Lee \\ (5) L. Liang
}

J. M. Loar

T. E. Myrick

D. E. Reichle

C. T. Rightmire

D. S. Shriner

D. B. Watson

O. R. West

Central Research Library

(2)

ESD Library

Laboratory Records Dept.

Laboratory Records, ORNL-RC

\section{EXTERNAL DISTRIBUTION}

F. J. Anderson, Environmental Restoration/Waste Management, Portsmouth Gaseous Diffusion Plant, P. O. Box 628, Piketon, Ohio 45661

M. Broido, Acting Director, Environmental Sciences Division, ER-74, Department of Energy, 19901 Germantown Road, Germantown, MD 20874

E. G. Cumesty, ORNL Site Manager, Department of Energy, Oak Ridge National Laboratory, P. O. Box 2008, Oak Ridge, TN 37831-6269

R. L. Gorres, Portsmouth Gaseous Diffusion Plant, P. O. Box 628, Piketon, Ohio 45661

T. C. Houk, Department of Energy, Portsmouth Site Office, Portsmouth Gaseous Diffusion Plant, P. O. Box 628, Building X-7725 Piketon, Ohio 45661-7602

L. Kantner, Department of Energy, Portsmouth Site Office, Portsmouth Gaseous Diffusion Plant, P. O. Box 628, Piketon, Ohio 45661-7560

Michael C. MacCracken, Director, Office of the U.S. Global Change Research Program, Code YS-1, 300 E Street, SW, Washington, D.C. 20546

A. Patrinos, Director, Office of Biological and Environmental Research, ER-70, Department of Energy, 19901 Germantown Road, Germantown, MD 20874

J. D. Sheppard, Department of Energy, Portsmouth Site Office, Portsmouth Gaseous Diffusion Plant, P. O. Box 628, Piketon, Ohio 45661

Office of Assistant Manager for Energy Research and Development, Department of Energy, Oak Ridge Operations, P.O. Box 2001, Oak Ridge, TN 37831-8600

(2) Office of Scientific and Technical Information, P.O. Box 62, Oak Ridge, TN 37831 